4 nordon 



\section{Nordic Blue Parks}

Nordic perspectives on underwater natural and cultural heritage

K. O'Brien, S.Tikkanen, C. Lindblad, P.Flyg, A. Olsson, O.Uldum, I. Aarestad, and D. Ncevdal 


\section{Nordic Blue Parks}

Nordic perspectives on underwater natural and cultural heritage

TemaNord 2010:597

(C) Nordic Council of Ministers, Copenhagen 2011

ISBN 978-92-893-2166-2

This publication is available as Print on Demand (PoD) and can be ordered on www.norden.org/order. Other Nordic publications are available at www.norden.org/en/publications.

This publication has been published with financial support by the Nordic Council of Ministers. But the contents of this publication do not necessarily reflect the views, policies or recommendations of the Nordic Council of Ministers.

Nordic Council of Ministers

Ved Stranden 18

DK-1061 København K

Phone (+45) 33960200

Fax (+45) 33960202

\author{
Nordic Council \\ Ved Stranden 18 \\ DK-1061 København K \\ Phone (+45) 33960400 \\ Fax (+45) 33111870
}

www.norden.org

\section{Nordic co-operation}

Nordic co-operation is one of the world's most extensive forms of regional collaboration, involving Denmark, Finland, Iceland, Norway, Sweden, and three autonomous areas: the Faroe Islands, Greenland, and Åland.

Nordic co-operation has firm traditions in politics, the economy, and culture. It plays an important role in European and international collaboration, and aims at creating a strong Nordic community in c strong Europe.

Nordic co-operation seeks to safeguard Nordic and regional interests and principles in the global community. Common Nordic values help the region solidify its position as one of the world's most innovative and competitive. 


\section{Content}

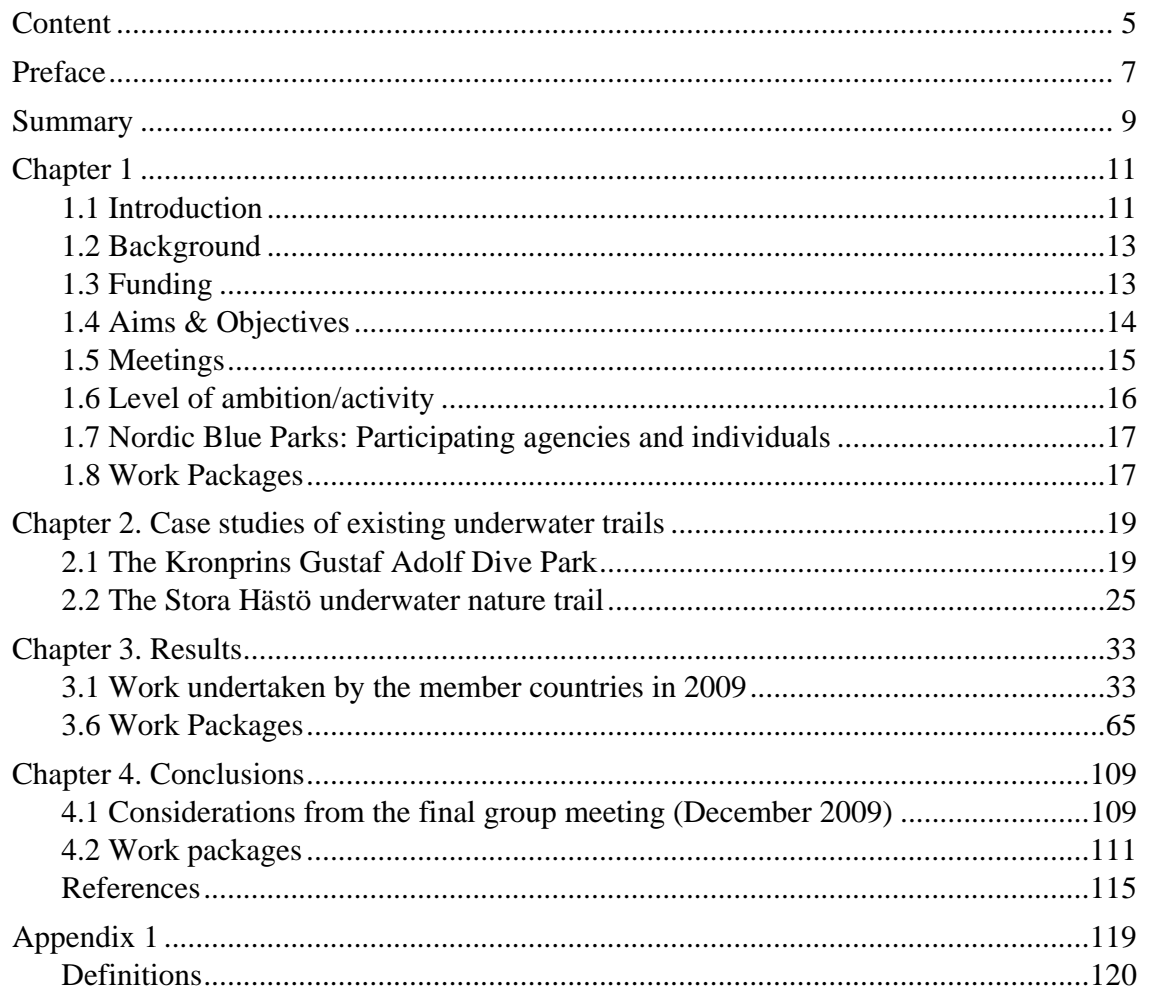





\section{Preface}

How can natural and cultural values be a resource for sustainable development in the Nordic countries? That is the question the Nordic Blue Parks project has tried to answer by providing case-studies of regional and local success stories, thereby assessing the possible synergistic effects of cross-sectoral working with both nature- and cultural heritage bodies. The project therefore highlights examples where a combination of natural and cultural heritage has been the foundation of social, economic and environmentally sound development. The project concentrates on three themes: nature and cultural heritage tourism, business development and a good living environment.

The Nordic Blue Parks project provides guidelines for national and regional authorities for setting up underwater natural and cultural underwater trails, according to the principles of sustainable development. This project, in encouraging people to be active outdoors, promotes an enriched outdoor life, while facilitating access to Nordic natural and cultural heritage through nature tourism and increases understanding of the efforts and behavioural changes required for this development to be sustainable.

The environmental sector in the Nordic Council of Ministers has expressed its priorities in a new Environmental Action Plan for 2009-2012. One of these priorities involves cooperation to help implement the European Landscape Convention. Another priority is to increase the knowledge of and make visible the significance of landscapes and cultural heritage for a good quality of life. It is the task of the Nordic Council of Ministers' Working group on Terrestrial Ecosystems to follow up these priorities.

Furthermore, the Working Group has initiated or contributed to several projects dealing with landscape, cultural heritage and the inter-linkages between them. This project aims to provide guidelines for national and regional authorities for setting up underwater natural and cultural trails according to the principles of sustainable development, i.e. by integrating these guidelines into policy and decision-making as stated in the general advice in the Strategy (TemaNord 2004: 568). 



\section{Summary}

Nordic Blue Parks is a new concept that combines underwater nature and cultural trails (wreck trails and trails at other anthropogenic sites and constructions under water). The project was initially designed to be a one year pilot, trying to formulate criteria and guidelines for sustainable blue parks and to set up trails to test these concepts in four Nordic countries, i.e. Finland, Sweden, Norway and Denmark.

Blue Parks are defined as areas with a set of one or more submerged natural or cultural objects/sites, and, when finalised, also has one or several underwater trails. Further, we define a Blue Trail as a set/planned "path" along which a diver or snorkeller travels when exploring a set of underwater ecosystems/habitats (natural object trail), wreck and/or other cultural underwater site (culture object trail). Prior to this project, no Blue Parks existed with defined and promoted natural and cultural underwater objects occurring simultaneously in a single specified area.

The project was encompassed in four work packages, involving fieldwork and culminating in a written report. All work packages were completed as agreed upon with the Nordic Council of Ministers. Nordic and national maps were compiled which give information on potential sites for underwater trails from each of the member countries. The combined experiences and meetings of individuals from the four member countries have led to the construction of a risk/threat matrix as well as a list of recommendations for the construction of future underwater cultural and heritage trails. The matrix tool allows a general rating of potential underwater trail sites based on their susceptibility over distance to natural and anthropogenic impacts. A list of threats/risk factors was also compiled. To further improve our outreach potential information on the Nordic Blue Parks project was also disseminated in a website, (www. nordicblueparks.com), with its own registered domain name. This complimented the various newspaper and magazine articles, TV/radio interviews and lectures and presentations made across the member countries.

All of this work is built on a firm knowledge base compiled from the results, recommendations and guidelines formulated from the projects' activities in 2009/10. Thus, not only will the Blue Parks and Trails reach their target group (snorkellers and divers), these innovative new approaches can be further adapted to facilitate access to the underwater heritage of a much wider audience in Nordic countries. The primary target group for the information work should be the general public, particularly children and young people. However, through innovative outreach approaches, interest could also be generated in other demographic groups. For example, other types of outdoors tourists, e.g. kayakers could be stimulated to visit a Blue Park to explore the underwater attractions, while a virtual dive park has the further advantage in 
reaching those who cannot as easily experience Blue Park on site, such as the elderly or disabled.

The Nordic Blue parks project shows a high degree of inter-sectorality because for the first time both natural and cultural administrations from several Nordic countries have cooperated synergistically concerning the underwater environment. While there has and continues to be an excellent opportunity for high profile media attention, further innovative outreach approaches through the use of high-tech methods and electronic media, allows the adaptation and extension of the original concept to much wider target groups. Through such a framework, the Nordic Blue Parks project ably integrates all three components of sustainable development. Firstly, through the development of underwater nature and culture trails, followed by the next level of development (2010+) to allow increased access of these resources to a wider general target audience, the environmental and social values are promoted sustainably. When combined, they provide new economic possibilities to develop local natural tourism, international cooperation, education and research, as well as cultural identity.

One of the greatest challenges in the administration of Nordic waters continues to be to develop strategies that include the sustainable usage of the sea's resources in their entirety, as well as promote co-operation that transcends borders, employment sectors and stakeholders. This project admirably tackles this issue because the underwater trails and the outreach programmes do not take anything away from the environments they promote. On the contrary, the Nordic Blue Parks project has created an international forum to foster ties not only between the various groups working regionally on this project, but also to engender links between the general public and their own cultural and natural resources. 


\section{Chapter 1}

\subsection{Introduction}

The Nordic region consists of Denmark, Finland, Iceland, Norway and Sweden, and the self-governed regions within Denmark and Finland, The Faroe Islands and Greenland (Denmark), and Åland (Finland), In addition, Nordic cooperation also includes the Baltic States and northwest Russia. These countries have shared a common history throughout the centuries, holding great similarities in their governance, language, culture and nature. They have a long tradition of cooperating on environmental protection issues and seek to achieve synergies which produce added value in national, regional and international contexts.

Nordic cooperation is organised through the Nordic Council, which consists of parliament members of the different countries, as well as the Nordic Council of Ministers, which consists of ministers within the relevant sectors of cooperation. The basis of Nordic environmental cooperation involves an extensive network of experts.

Although there are significant differences in population density over the area, with only 25 million inhabitants, the Nordic region is relatively sparsely populated. Nevertheless, in the Nordic landscape, human interdependence with nature has left its mark, such that natural resources have been the foundation for human culture, lifestyle and identity in this region.

The environmental sector in the Nordic Council of Ministers has expressed its priorities in a new Environmental Action Plan for 2009-2012. One of these priorities involves cooperation to help implement the European Landscape Convention. Another priority is to increase the knowledge of and make visible the significance of landscapes and cultural heritage for a good quality of life. It is the task of the Nordic Council of Ministers' Working group on Terrestrial Ecosystems to follow up these priorities. The Working Group has initiated or contributed to several projects dealing with landscape, cultural heritage and the inter-linkages between nature and cultural heritage.

How can natural and cultural values be a resource for sustainable development in the Nordic countries? That is the question this project has tried to answer by providing case-studies of regional and local success stories, thereby assessing the possible synergy effect of cross-sectoral working with both nature- and cultural heritage. The project therefore highlights examples where a combination of natural and cultural heritage has been the foundation of social, economic and environmentally sound development. The project concentrates on three themes: nature and cultural heritage tourism, business development and a good living environment. For more information on the Nordic Council of Ministers' environmental work, visit their website at 
www.norden.org. In addition, if you would like to know more about their specific projects, please contact Jannica Pitkänen-Brunnsberg (jannica.pitkanen-brunnsberg@metsa.fi),coordinator, or Ms. Anna Helena Lindahl (anna.helena.lindahl@naturvards-verket.se), chairperson for the Working Group on Terrestrial Ecosystems.

\section{The Nordic Blue Parks project \& the Nordic Strategies for Sustainable Development}

This project aims to provide guidelines for national and regional authorities for setting up underwater natural and cultural trails according to the principles of sustainable development, i.e. by integrating these guidelines into policy and decision-making as stated in the general advice in the Strategy (TemaNord 2004: 568). Furthermore, it fulfils the criterion of Nordic cooperation in the Strategy by "offering advantages of scale and opportunity to exchange knowledge, expertise and methodologies among the Nordic countries". In addition, the rational conservation work and increased information as promoted in chapter 5 is to a very high degree acknowledged by the Nordic Blue Parks project. Moreover, in the same chapter, the ecosystem approach is promoted through the information presented at the nature Blue Trails. This project also promotes access to the countryside and supports efforts to promote the cultural environment (TemaNord 2004: 568, chapter 5).

Consequently, the Nordic Blue Parks project also links to the more recent Nordic Council of Ministers' Environmental Action Plan for 2009-2012. In Section 1.1 of the report, strong emphasis is placed upon health and wellbeing, which are both connected to a sound living environment. This project, in encouraging people to be active outdoors, promotes an enriched outdoor life, while facilitating access to Nordic natural and cultural heritage through nature tourism increases the understanding of the efforts and behavioural changes required for this development to be sustainable. Moreover, in Section 3 of the Environmental Action Plan, it is stated that one of the greatest challenges in the administration of Nordic waters is to develop strategies that include the sustainable usage of the sea's resources in their entirety, as well as promote co-operation that transcends borders, employment sectors and stakeholders. This project admirably tackles this issue because it creates an international forum (Sections 3, 5) to foster ties not only between the various groups working regionally on this project, but also to engender links between the general public and their own cultural and natural resources. In doing so, the project also "transcends borders and stakeholders", closely reflecting the prioritised areas of Section 5, where co-operation shall be targeted on creating conditions for the exchange of information, experiences and knowledge across national borders, and most importantly, initiating and supporting other initiatives. It could also strengthen the project by adding a culture heritage perspective and Baltic identity. 


\subsection{Background}

In the Nordic countries, our underwater cultural heritage has been exceptionally well preserved throughout the centuries. Similarly, the natural world under the waves is habitat rich, with a fascinating array of plant and animal species. Nevertheless, the underwater secrets and treasures have thus far only been revealed and accessible to a relatively small group of sports divers and those with archaeological knowledge, remaining largely unknown to the general public. The core of this project is a concept which combines underwater nature and culture trails. The Nordic Blue Parks project is based on recent or existing initiatives or reports from the various member countries. See Table 1 for some examples. The concept of underwater trails/parks is not a new one. Other examples of international schemes already exist in Australia, the USA, Norway, Britain and the Red Sea, with which we might make comparisons from our own data. Australia has a number of wreck trails, which include Rottnest Island, Perth, as well as the Mandurah, Hamlin Bay and Freemantle wreck trails. More information can be found in Table 2.

\subsection{Funding}

The idea for this project application where underwater cultural and natural heritage is acknowledged within one project was suggested by the Nordic Council of Ministers (NCM) and the group for nature, outdoor life and culture (Grupp for Natur, Friluftsliv och Kultur - NFK). The initial sum promised by the Nordic Council of Ministers (NCM) was only 700000 DKK, as opposed to the 1.29 million DKK requested in the original application. It was decided that this would cause problems and severely limit the scope of the Blue Parks project. While the NFK decided not to fund the initial Blue Trails application submitted by Metsähallitus in 2007, it chose instead to provide 100000 Danish kroner for setting up a planning meeting and for the compilation of a new application. Following this meeting, a second application was made in June 2008 with a total budget of 1.97 million Danish kroner, of which 1.29 million DKK was applied from the Nordic Council of Ministers. The funding decision was reviewed and in December 2008 and an additional sum was added, which was further raised in January 2009, bringing the total grant to 1.2 million DKK. 
Table 1. Examples of previous projects and initiatives upon which the Nordic Blue Parks project is based.

\begin{tabular}{lll}
\hline Country & Project/Report & Web address/Link \\
\hline Finland & $\begin{array}{l}\text { MOSS project } \\
\text { Kronprins Gustav Adolf wreck trail } \\
\text { (National Board of Antiquities) }\end{array}$ & $\begin{array}{l}\text { www.nba.fi/internat/moss/ } \\
\text { www.nba.fi/en/gustavadolf }\end{array}$ \\
& $\begin{array}{l}\text { Stora Hästö underwater nature trail } \\
\text { (Metsähallitus Natural Heritage Services) }\end{array}$ & www.metsa.fi \\
Sweden & $\begin{array}{l}\text { Report of valuable underwater cultural } \\
\text { environments on the } \\
\text { Swedish coast and archipelago. }\end{array}$ & $\begin{array}{l}\text { www.naturvardsverket.se/Docu- } \\
\text { ments/publikationen/620-5566-6.pdf }\end{array}$ \\
& $\begin{array}{l}\text { MACHU Interreg IIlc project } \\
\text { NCM RUTILUS project }\end{array}$ & $\begin{array}{l}\text { www.machuproject.eu } \\
\text { www.sjohistoriska.se }\end{array}$ \\
\hline
\end{tabular}

Table 2. Examples of international underwater trail schemes already in existence.

\begin{tabular}{lll}
\hline Country & Location & Web link \\
\hline Australia & $\begin{array}{l}\text { Multiple locations } \\
\text { King Island, } \\
\text { Tasmania } \\
\text { Multiple locations }\end{array}$ & $\begin{array}{l}\text { www.environment.sa.gov.au/heritage/shipwreck_trails.html } \\
\text { www.kingisland.net.au/ maritime/ }\end{array}$ \\
& www.museum.wa.gov.au/collections/maritime/march/publications.asp \\
USA & $\begin{array}{l}\text { Florida } \\
\text { Plate Fleet }\end{array}$ & $\begin{array}{l}\text { www.flheritage.com/archaeology/underwater/maritime/index.cfm } \\
\text { www.flheritage.com/archaeology/underwater/galleontrail/ }\end{array}$ \\
& Lake Champlain, & www.shipwrecktour.com
\end{tabular}

\subsection{Aims \& Objectives}

At the kick-off meeting the project's aims and objectives were formulated as well as dividing the project work into four work packages. Our intention was to use the sites and monuments register to create GIS layers on the location of shipwrecks and other underwater cultural sites and use these for making overlay analyses to identify a suitable set of sites with underwater cultural and nature values (marine nature conservation areas, marine landscapes and, where possible, with marine habitats).

The objectives of the Blue Park projects are:

- To carry out a status /quality assessment of suitable sites for setting up a Blue Park

- To carry out a threat assessment for underwater sites with artefacts and sites with high nature values and natural beauty

- To define the general principles for setting up a Blue Park \& Blue Trails 


\subsection{Meetings}

On the 12th and 13th of February 2009, the first kick-off meeting of the Nordic Blue parks project took place at the headquarters of Metsähallitus/Forststyrelsen in Helsinki, Finland. In attendance were intersectoral agencies representing nature and culture from Finland, Sweden and Norway. No Danish representatives had been found at this time. Moreover, none of the overtures (e-mail and letters) made to include potential Icelandic members resulted in any interest on their behalf to join the Blue Parks project.

At this kick-off meeting, it was decided that the core of the Blue Parks project lies in the two-fold approach of developing natural and cultural heritage, the output from which should include not only increase public awareness in these heritage aspects, but also integrate their sustainable development. Powerpoint presentations were given, which covered both the cultural and natural heritage of the Finnish and Swedish partners.

Along these themes, the representatives from the Swedish National Maritime Museums (NMM) outlined their outreach concept or "Dalarö Model”. The salient points of this model are as follows:

- The aim is to increase awareness of the need to conserve shipwrecks among wreck divers and non-divers alike.

- Wrecks are surveyed and given a sensitivity status. These statuses are ranked and the most sensitive sites are protected by prohibition measures.

- A wreck's status may change over time due to diving pressure.

- The combination of these ideas is that nature and culture should also be linked to awareness, conservation, prohibition, etc., to set a good example for and create a good working relationship with the various target groups.

- In effect, a more holistic approach is taken, which allows Park/trail managers to look at the "bigger picture".

The NMM representatives further suggested that 50-100 sites of high natu$\mathrm{ral} /$ cultural value which may be suitable for Blue Trails should be selected per country. Of these, 10-20 sites with more detailed descriptions should be selected which can show us the consequences of overlapping sites in terms of their location, infrastructure, etc. In compiling this data, we would need to determine some concept of site quality. For example, a hierarchical system could be used: Low; Medium; High; Highest, etc. It was further proposed that sites up to and including those in the "High" category may be sufficient as potential locations for Blue Trails, with those in the "Highest" bracket omitted in order to preserve them.

However, both of the Norwegian Blue Parks members had serious concerns regarding the lack of information in Norway, compared to Finland and Sweden. They stated that although there are potentially thousands of wrecks 
along the extensive Norwegian coast, very little is known about the majority of sites, their georeferences or their provenance. Therefore, using the NMM proposals above would be very difficult to apply for the Norwegian partners and stated that individual wreck trails would be easier to develop than a park per se.

\subsection{Level of ambition/activity}

The above discussions led to an overall question about the "level of ambition/activity" among the Nordic Blue Parks partners. For example, some member countries, i.e. Finland, have already constructed underwater trails prior to this project, others have new trails about to come online (Sweden), while some had no trails at all. Further, some member countries, i.e. Sweden, already possessed an advanced infrastructure and facilities coming into this project upon which to launch their ideas and plans, with the other countries being less developed.

Although we lacked a Danish contingent at this stage due to difficulties in finding suitable candidates, the project coordinator, Kevin O’Brien (Metsähallitus) travelled to Copenhagen to meet two potential Nordic Blue Park members in June 2009. Unfortunately, the Danish natural heritage partner was unable to join the Blue Parks project due to its short time-frame (among other issues). Nevertheless, the June meeting resulted in the addition of an underwater cultural representative for Denmark, i.e. Otto Uldum, from the Langelands Museum.

More recently, $1 \frac{1}{2}$ days of meetings spanning the 9th and 10th of December 2009, were held again at Metsähallitus headquarters in Helsinki.The purpose of these meetings was to compile experiences (positive and negative) of the various members gained through the construction of underwater trails and the development of underwater heritage in Finland, Sweden, Norway and Denmark. Our overall findings are presented in the conclusions section (Section 4). 


\subsection{Nordic Blue Parks: Participating agencies and individuals}

Table 3. The institutions and individuals which have participated in the Nordic Blue Parks project.

\begin{tabular}{lll}
\hline Country & Natural heritage & Cultural heritage \\
\hline Finland & $\begin{array}{l}\text { Metsähallitus/Forststyrelsen } \\
\text { Jan Ekebom, Kevin O'Brien }\end{array}$ & $\begin{array}{l}\text { National Board of Antiquities } \\
\text { Sallamaria Tikkanen, Salla Pärssinen }\end{array}$ \\
Sweden & $\begin{array}{l}\text { Swedish Environmental Protection } \\
\text { Agency }\end{array}$ & $\begin{array}{l}\text { National Maritime Museums } \\
\text { Andreas Olsson, Pernilla Flyg }\end{array}$ \\
& Cecilia Lindblad & Directorate for Cultural Heritage \\
Norway & County Governor of $\varnothing$ stfold & Ivar Aarestad \\
& Aase Richter-Withdrew & Norwegian Maritime Museums \\
& & Desiree Nævdal \\
& & Langelands Museum \\
Denmark & No partner† & Otto Uldum \\
\hline
\end{tabular}

* Langelands Museum has since merged with another museum to form the Øhavsmuseet (Archipelago Museum). † No Danish partner was found in 2009 for natural heritage.

In November 2009, the County Government of Østfold, who had initially planned a Blue Trail in the Ytre Hvaler National Park, informed us that they would let the Directorate of Nature Management take over the partnership role in the Blue Park-project. At the time of writing this report, no follow up person was found as a replacement. Similarly, no Danish partner was found to address the development of natural underwater heritage.

\subsection{Work Packages}

The Nordic Blue Park project was divided into four work packages (WP’s):

\subsubsection{WP1: Status/Quality Assessment of nature and culture sites}

Involves the preparation of standards for carrying out assessments by:

- Identifying and ranking the sites with high cultural and nature values occurring simultaneously (yet still resilient to impacts by visitors)

- Identifying a top set of sites most suitable for establishing a Blue Park with Blue Trails (dive trails) acknowledging resilience, accessibility and the "good story" of the site (facilitating the marketing of the site)

\subsubsection{WP2: Pressure \& Threat Assessment}

This work package builds on existing pressure and treat assessment lists (matrices), e.g. identified by the EU's Marine Strategy Framework Directive 2008/56/EC, UNESCO's Intergovernmental Commission (Ehler \& Douvere, 
2009) and the Marine Life Information Network (MarLIN), covering natural and anthropogenic pressures and threats. The third pressure evaluation method derives from the BALANCE project (www.balance-eu.org). Currently, no previous attempt to combine the list of threats to underwater nature and cultural has been carried out, making this the first of its kind.

\subsubsection{WP3: Blue Park General Principles for Management Guidelines}

This work package involves the creation of general principles for management guidelines for Blue Parks and Blue Trails (based on the experiences from case study sites, one cultural and one natural site and/or trail in each of the four project member countries). In addition, we formulate definitions for these principles, using the terms Blue Park and Blue Trail (what is generally offered to the visitor (infrastructure, facilities, information), the security rules (no hunting or net fishing allowed, no looting, diving security and principles, rescue plans). We also define the general principles for the Blue Park management, i.e. what management guidelines should include and demonstrate this by providing a first set of basic guidelines (but not official management plans, or detailed guidelines, since these are outside the scope of a project of this size).

\subsubsection{WP4: Project co-ordination and dissemination of results}

The project co-ordination includes: project management (financial management, sharing advice on project participation), being the focal point for communication between project partners (shared advice on project, chairing of meetings, creating of the project website, compiling the project's final report (based on contributions from project partners). 


\section{Chapter 2. Case studies of existing underwater trails}

\subsection{The Kronprins Gustaf Adolf Dive Park}

by Sallamaria Tikkanen, National Board of Antiquities, Maritime Archaeology Unit, Helsinki, Finland.

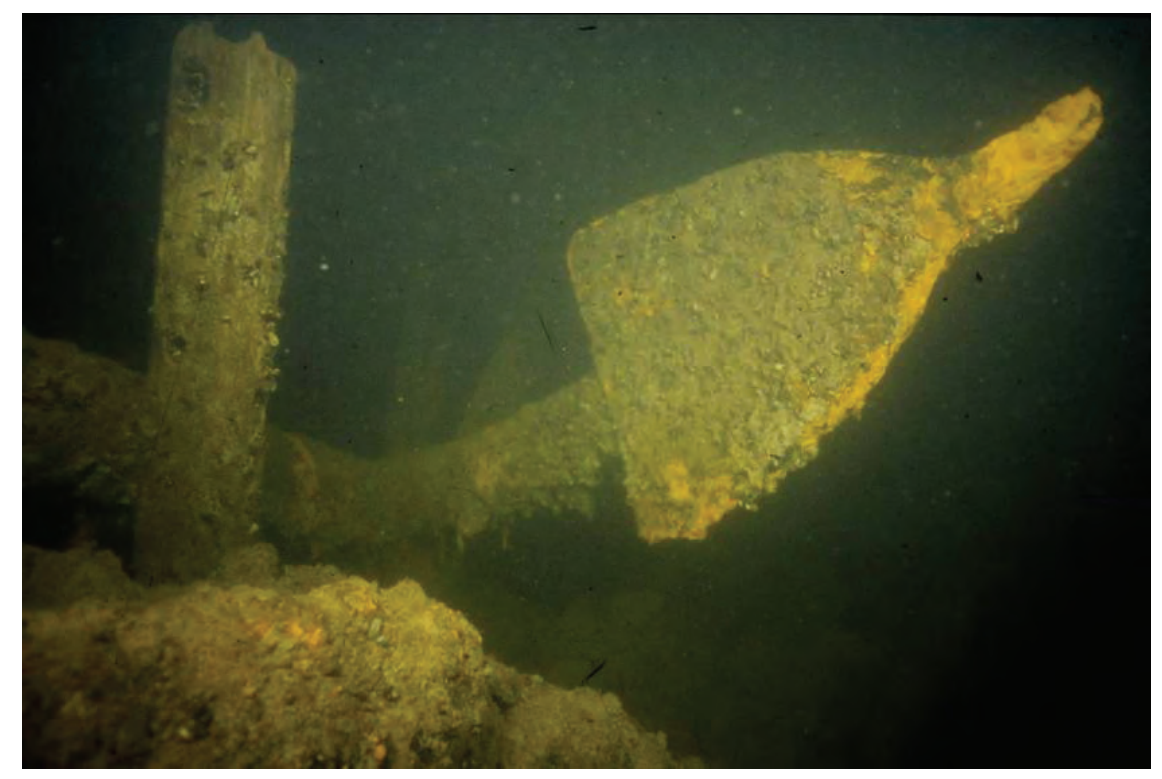

The anchor of the Kronprins Gustaf Adolf. Photo: National Board of Antiquities

\subsubsection{Background}

Historic shipwrecks represent significant elements of our common past and they are becoming increasingly recognised as important marine resources for research, interpretation, tourism and education. One of the basic principles of the ICOMOS Charter on the Protection and Management of Underwater Cultural Heritage (signed in 1996) has been to preserve the underwater cultural heritage in situ. Additionally, it is written in the 1999 ICOMOS draft of the International Cultural Tourism Charter that: "Reasonable and well managed physical, intellectual and/or emotive access to heritage and cultural development is both a right and a privilege".

The idea of underwater parks supports both of these principles. Experiences gathered around the world have shown that underwater parks, when managed successfully, are an excellent way to enhance as well the in situ 
preservation of underwater cultural heritage as well as improving the accessibility of sites to the general public.

\subsubsection{What is the concept of underwater parks?}

Underwater cultural heritage has traditionally been presented to the general public in museums, or by lifting whole shipwrecks. Another way is to create so-called "underwater parks" where diving enthusiasts can follow underwater historical paths and become acquainted with the site. Along the ropelined path are a series of information signs about the history of the site and about the artefacts, structures and details to be found in the wreck. The diving support vessels arriving to the park are fastened to a buoy outside the immediate area - rather than anchoring, which destroys the site. A guiding line takes the diver down from the buoy to the target.

Underwater parks offer waterproof maps of the site for divers and usually also a normal paper brochure telling the story of the site is available, too. Additionally, information about diving conditions, safety regulations, and emergency contacts is provided. The non-diving public can learn about the site by exploring them through exhibitions, video presentations etc. In some cases the target can be observed from a glass-bottomed vessel or from a small submarine or half submarine. Shallow water sites may also be visited by skin divers. Some underwater sites offer visitors a chance to watch marine archaeologists at work, take underwater photographs guided by an expert, or take part in an introductory course on marine archaeology. How may we identify an underwater park? For example, terms like "preserve”, "underwater historical preserve", "marine sanctuary", "underwater museum" and "underwater heritage/maritime/shipwreck trail” have been used. I feel that the term "underwater park" best describes the notion of a managed area open to the diving public.

In underwater parks, attempts are made to preserve the site as much as possible in its original condition and to favour non-destructive techniques in the investigations preceding the foundation of the park. The first underwater parks were opened on the Great Lakes in the 1970's, the concept being copied from land-based historical parks. For example, underwater parks have been introduced in the US, Canada, Australia, Sicily, Britain, Israel and Egypt. The experiences all over the world have been very positive.

Shipwrecks suitable for underwater parks can be selected for a variety of reasons; for example for their historical and natural values or a site provides just an enjoyable underwater experience. One type of underwater park is those which have some kind of theme. For example, in Adelaide, southern Australia there is an underwater heritage trail which includes four shipwrecks. Each of these vessels demonstrates the four major types of materials used in sailing vessel construction; wood, composite, iron and steel. The wrecks span the period of British shipbuilding from 1841 to 1893. Another theme park in South-Australia consists of shipwrecks which were associated with Port Victoria as an important trading port in the early 1900's. 
Underwater parks can also feature other types of underwater cultural heritage than shipwrecks. For example in Ustica, Sicily, the underwater trail includes a lead-stock and a Byzantine iron anchor, while in Caesarea, Israel, divers can explore the structures of an ancient harbour. Underwater parks can be also parts of wider maritime heritage trails. For example, in South Australia the "River Boat Trail" on the River Murray includes - among other sites and places - over 60 shipwrecks, a lighthouse, 12 wharves, 24 jetties, a morgue and 16 surviving historical vessels.

The selected sites should be designated as an underwater park through a cooperative project between public, divers and government. The development of a new park is an excellent opportunity for a diving group to become involved in an underwater project with lasting results. By placing underwater resources in the public trust and by explaining their archaeological and historical value, the sites become important for everyone to preserve.

\subsubsection{The Wreck of the Kronprins Gustav Adolf}

The Kronprins Gustav Adolf was built in Karlskrona in Sweden in 1784 and was designed by the famous naval architect Fredrik Henrik af Chapman. The wreck is a Swedish 62-cannon ship of the line that ran aground on an uncharted rock during the wars of King Gustav III in 1788. Russian ships had chased the Gustav Adolf and captured it after it ran aground. The crew was taken prisoner and the ship set on fire. The Kronprins Gustav Adolf was found in 1995 during a side scan sonar survey made by The Naval Research Institute of the seabed off Helsinki. Divers from the Coast Guard checked the location and reported the wreck of a large wooden warship. The wreck is located about 3.5 nautical miles south-south-west of the Harmaja lighthouse off Helsinki. The ship's remains lies at a depth of 18-20 metres on a flat bed of moraine and is partly scattered over an area measuring approximately 100 $\mathrm{x} 100$ metres.

The part of the wreck still intact consists of the bottom part of the hull, the sides, which have collapsed, as well as different structural parts, such as the rudder, and about 70 guns, cannonballs and other loose articles. There is a large bent anchor in the middle of the wreck and another just outside the aft. The cannons are covered by a thick layer of rust. The massive oak structures of the wreck are in good condition. Scattered around the wreck there are some large structural parts of the hull. The length of the wreck is nearly 40 metres and is approximately 15 metres in width.

The National Board of Antiquities investigated the wreck in 1997-1999 and on the basis of these field investigations the wreck was identified as the Kronprins Gustav Adolf. The main evidence for this identification includes:

- the wreck's position

- the number and type of guns and their inscriptions

- the hull measurements, rudder and anchor 
- the fact that the vessel has been on fire

- oak as building material

- the type and location of the finds and structures

All of these features correspond with a typical the ship of the line like Kronprins Gustav Adolf and are consistent with the facts found in literature and archives. Unfortunately, no name plate, royal insignia or ship's bell have been found; such proofs of the ship's identity have probably been looted or destroyed.

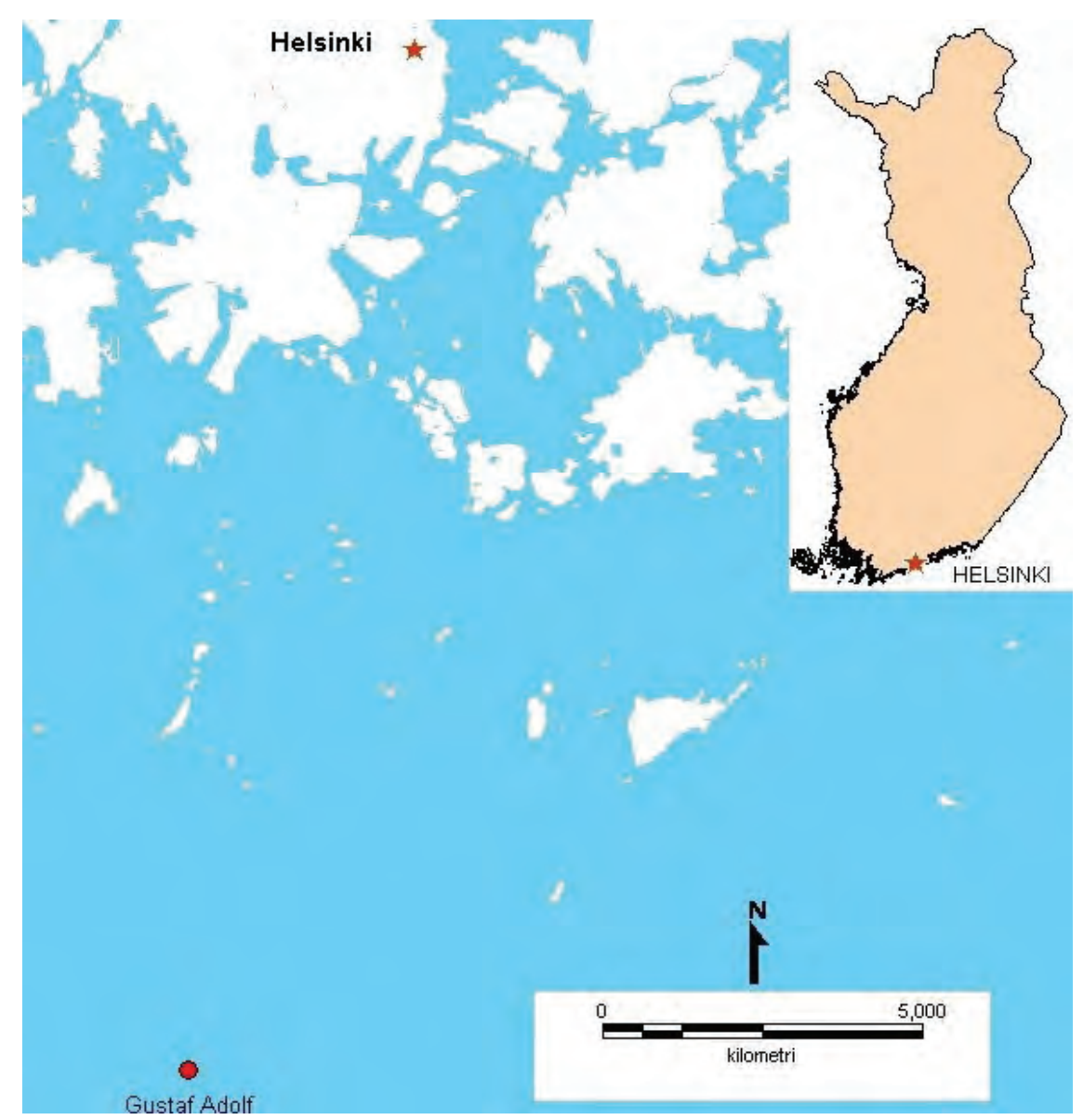

The location of the wreck of the Kronprins Gustaf Adolf (WGS84: N60.050, E24.921), situated 3.5 nautical miles south-south-west of the Harmaja lighthouse off Helsinki.

\subsubsection{The Kronprins Gustav Adolf underwater park}

The wreck of the Kronprins Gustav Adolf is very suitable site for an underwater park: it is open and in firm condition without many loose artefacts. Even though the only remaining parts of the ship are the bottom and the fallen sides, as well as cannons and cannon balls, the wreck gives a good picture of the bulk and size of a late 18th century large ship of the line. Diving at the site is pleasant; visibility at the wreck - at a depth of twenty metres - usually varies 
from four to seven metres. Additionally, the site is easy to access and there are several charter boats organised by dive shops available.

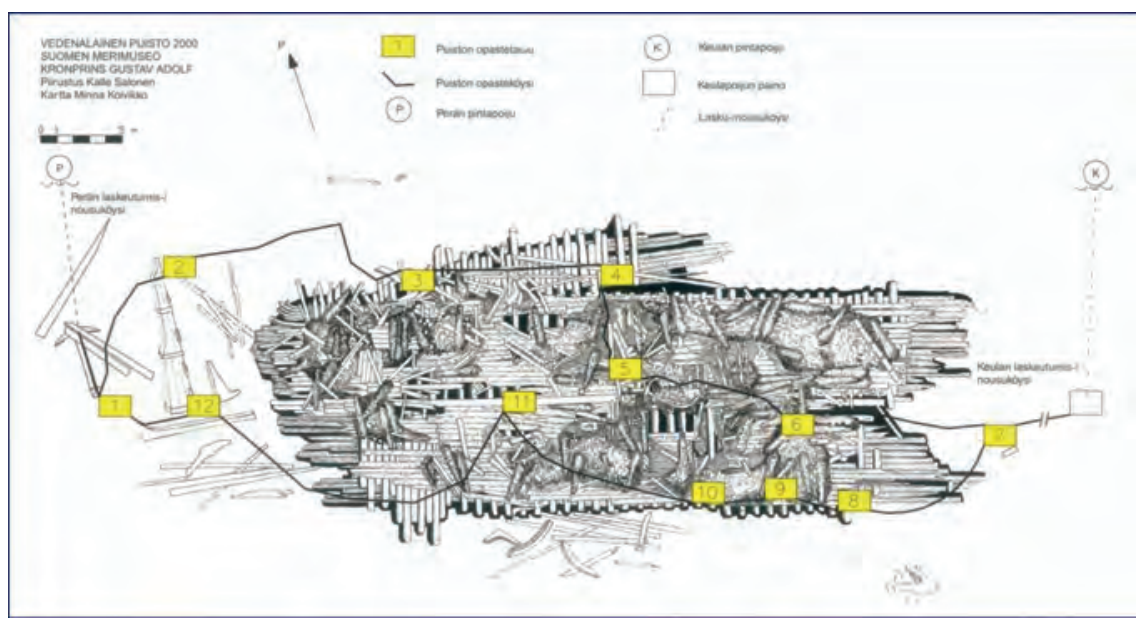

Plastic site map card showing the position of the mooring buoys, ropes leading down to and around the wreck, as well as the position of the various information plates along the wreck trail. (C) National Board of Antiquities.

The budget for the "Ships lost at sea" exhibition provided an excellent opportunity to open the underwater park. Information about this shipwreck has been disseminated in the form of a printed brochure introducing the underwater park and an article entitled, "The ship of the line Kronprins Gustav Adolf - a Swedish warship wrecked in 1788” was published in the Maritime Museum of Finland's Annual Report in 2000. In addition, an internet site (in Finnish, English and in Swedish) was created, which included an e-mail address for visitors to give feedback (http://www.nba.fi/en/mmf_park). The fact that the story of Kronprins Gustav Adolf is well-known from archives and literature adds to the public interest in the wreck.

Visitors can learn more about the site in advance from the brochure and a plastic diver's site map detailing interesting facts about the wreck, which divers can purchase and take along on their wreck trail tour. When divers know the site and its story, the dive experience is more enjoyable and safe. The brochure contains the following information:

- The concept of underwater parks

- Basic information (location, map, etc.)

- Procedures for visiting the site

- The story of the Kronprins Gustav Adolf

- A summary of legislation concerning underwater cultural heritage

- Regulations on how to use the park and how to dive safely

- How to moor the boat

- Weather and wind limitations

- Contact numbers and web address 
In addition, all thirteen underwater signs are described in the brochure. Divers can also give feedback and opinions about their experiences by sending electronic or ordinary mail. When divers visit the underwater park of the Kronprins Gustav Adolf, transportation boats are required to tie up to mooring buoys available at the site. A guiding line takes the divers from the buoy down to the wreck.

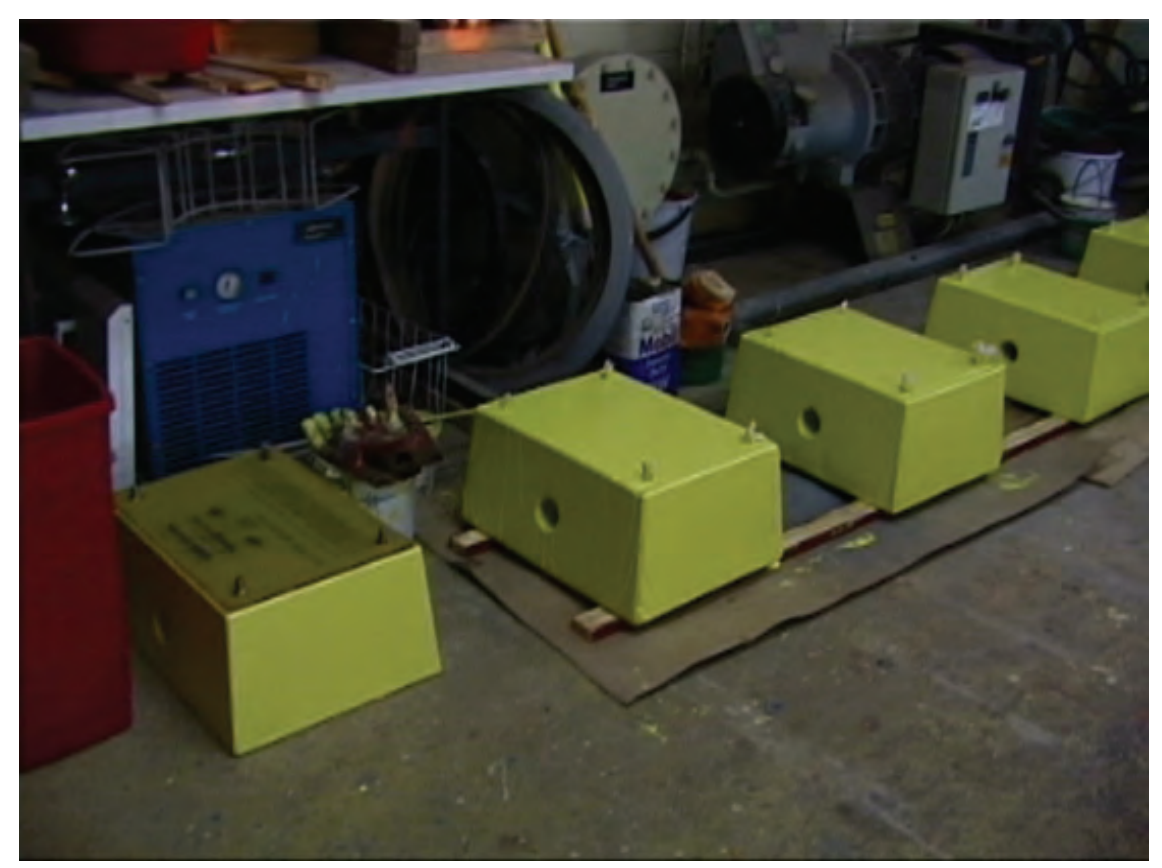

Kronprins Gustav Adolf on-site equipment: Yellow painted concrete weights and a plastic information sign.

Photo: Maritime Archaeology Unit.

At both ends of the guiding line there are separate signs with information on the location, i.e. stern or bow of the wreck. Divers can explore the wreck and its history in detail with the help of the thirteen information signs placed in the wreck. The signs are placed along a rope path which is fitted with direction arrows. Divers may leave their feedback on an underwater guestbook. 


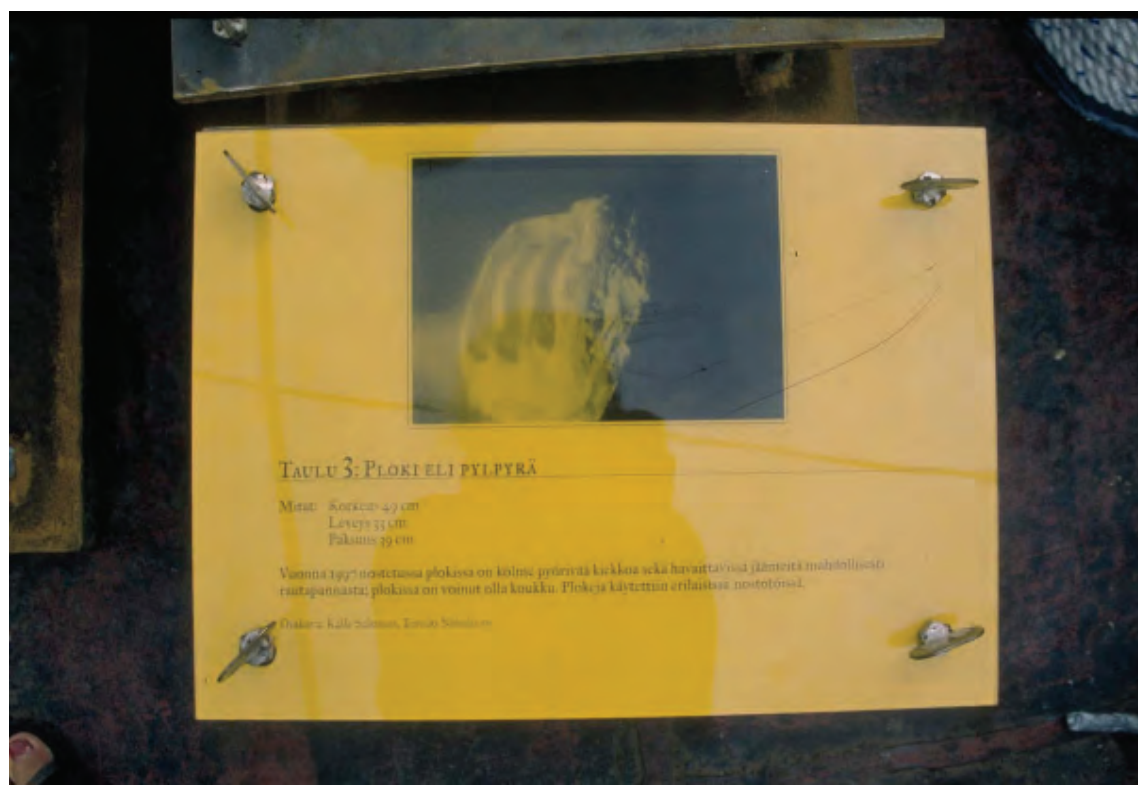

Kronprins Gustav Adolf on-site equipment: a plastic information sign. Photo: Maritime Archaeology Unit.

\subsection{The Stora Hästö underwater nature trail}

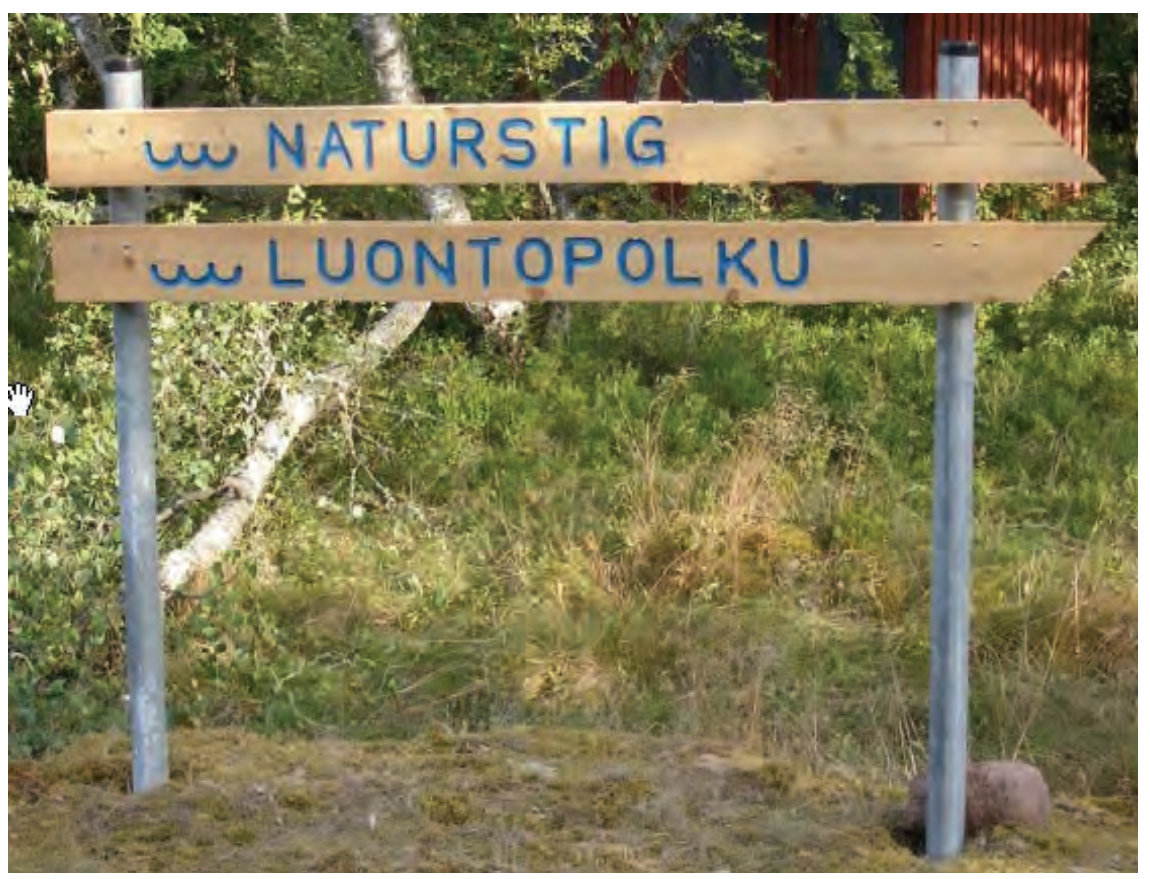

Sign on the island of Stora Hästö directing visitors to the start of the underwater nature trail. Photo: Heidi Arponen/Metsähallitus 


\subsubsection{Background}

Following a meeting with the marine archaeologists involved in the underwater park and shipwreck trail of the Kronprins Gustav Adolf, at Hylkysaari, Helsinki, the Natural Heritage Services of Metsähallitus were so impressed that the idea of an underwater nature trail was born as a "sister" to the shipwreck-trail. The original aim of the nature trail was to arouse further interest in this marvellous natural resource for all visitors to the Archipelago Sea and to enrich the experience by offering a whole new dimension of nature to enjoy.

Testing the underwater nature trail began in 2005 on the island of Stora Hästö, situated approximately five kilometres south west of the Korpoström Archipelago Research Centre, in the Archipelago National Park, in south west Finland. Visitors come regularly to the island to enjoy the terrestrial nature path, including the existing facilities such as a spot for camping, a fireplace, toilets and information boards. The underwater nature of this area is both diverse and interesting and along the underwater trail one can experience rocky shores which support seaweed communities, as well as the sandy seabed, where sea grass meadows grow. These plant communities support many species of fish and small invertebrates.

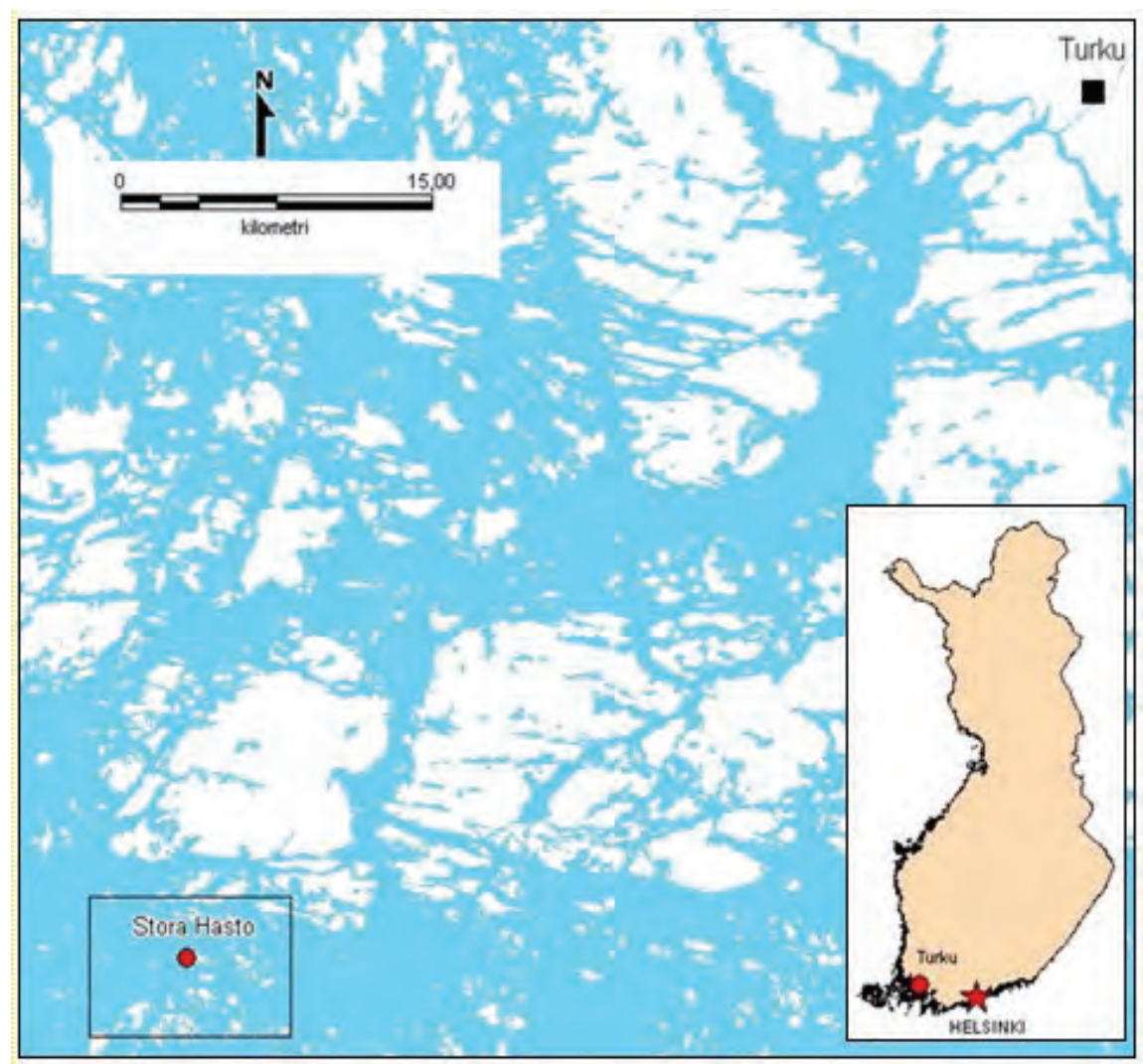

Stora Hästö, Finland's first underwater nature trail. 


\subsubsection{Trail Construction}

Construction of the dive-path began during the summer of 2006. Ultimately, the first season was a test to see whether the general public would be interested in such a nature experience. Moreover, it was considered easier to first construct a simpler and shorter trail and then modify it in the future if necessary. Initially, there were eight plastic text plates attached to square pieces of concrete, each informing about some species or particular aspect of Baltic marine ecology (e.g. blue mussel, i.e. Mytilus trossulus colonies, eutrophication, seagrass (Zostera marina) meadows). The plates were connected with approximately 200 metres of rope, to prevent the snorkellers/divers from becoming lost. The trail started at low water close to the shore and continued until unto a depth of 8 metres. A waterproof underwater guest book was placed at the beginning of the trail.

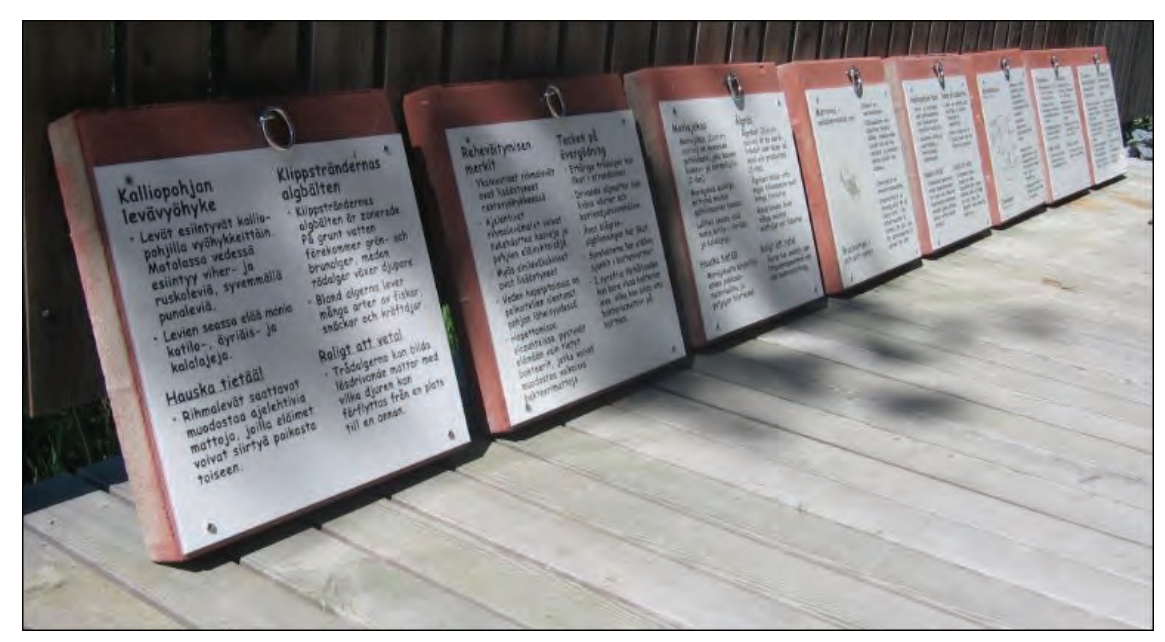

The original eight plates used on the 2006 trail. Information is given in Finnish and Swedish. Plates were linked by ropes using the bolt and ring assembly.

Photo: Heidi Arponen/Metsähallitus

Practically speaking, once a suitable site had been found, it was quite inexpensive to construct the underwater nature trail. The plates were ordered from a plate printing company: eight plates cost less than 100 euros (2006 prices). In addition, plastic ropes, metal carabiners, clips and plastic buoys were used, all of which could be easily found in regular boating/marine shops. Although it took only two days for two divers to construct the trail, it required regular maintenance (cleaning of loose algae from the ropes, etc.).

\section{Safety Issues}

Special attention was paid to certain specific safety issues for divers and snorkellers. These included: 
- the prohibition of boat traffic near the trail area

- no loose ropes or sharp items in the trail materials

- easy access to the water

\section{Problems \& visitor feedback}

Based on the feedback left on the waterproof guest book, the trail was visited regularly during the first summer and overall the feedback was very positive. Issues included:

- The main "complaint" was that the end part of the trail was too deep for snorkellers and the beginning too shallow for scuba divers

- Getting in and out of the water was also sometimes difficult for visitors as the rocks were uneven and sometimes slippery with algae

- Trail visitors also hoped for more pictures in the plates, in order to better recognise the species in the water

- The concrete garden paving plates used to anchor the attached information plates were not heavy enough to keep the assembly in place in very shallow water, as the waves in the rocky areas were sometimes strong enough to move the concrete slabs. Consequently, for the following season (2007), it was decided to install two plates bolted together. By comparison, a single concrete plate was sufficient at deeper locations. While a heavier assembly ensures more stability for the trail construction, excessive weight means that the plates become impossible to handle on the surface

- Some visitors requested more information

\subsubsection{Trail modifications and solutions in 2007-2008}

As of 2008, the trail consists of two routes, a shallower one for snorkellers lined with orange rope, and a longer, deeper trail for divers, marked with blue rope. Both trails share a common start and finish point. The whole route is approximately 200 metres in length. Both routes have information plates placed strategically along their path and marked with buoys, imparting information in Finnish and Swedish on the flora and fauna to be found there, as well as some information on the unique ecology of the Archipelago Sea.

The routes are easy to follow using the marked ropes, starting from a large white buoy (marked with the word START in red letters), situated close to the entry point. The information plates lie at depths of 0.5 to 5 metres. On the snorkel trail most can be read while floating on the surface, while the deeper plates are intended for divers. Floating plastic rope was used to connect the plates, since it was cheaper and more durable than sinking ropes. In addition, small Styrofoam buoys were inserted in the middle of the rope between each of the plates, to lift the rope off the bottom (about 40 $\mathrm{cm})$. This helped to reduce the build up of loose algae.

The plate material was changed to a more durable one, made of aluminium covered with a plastic layer, onto which the text is printed. The number 
of information plates increased from eight to ten. Additional graphics were added as per visitor's requests. Many of the original concrete paving slabs were replaced with thicker, heavier ones, measuring $50 \times 45 \mathrm{~cm}$ with an additional stainless steel chain and yellow plastic buoy added to each plate to make them easier to find in the occasionally poor visibility. A wooden stairs was built onto the bedrock near the start point of the trail, which greatly facilitated entry and exit from the water.

A sign containing safety information, e.g. the coordinates of the trail, numbers to call in case of emergency was placed near the wooden steps. Additional information on this sign includes a disclaimer of responsibility by Metsähallitus in case of accidents, a directive that snorkellers and divers should follow the code of practices used by the Finnish Diving Association and a reminder that boaters should not anchor on or near the underwater trail.

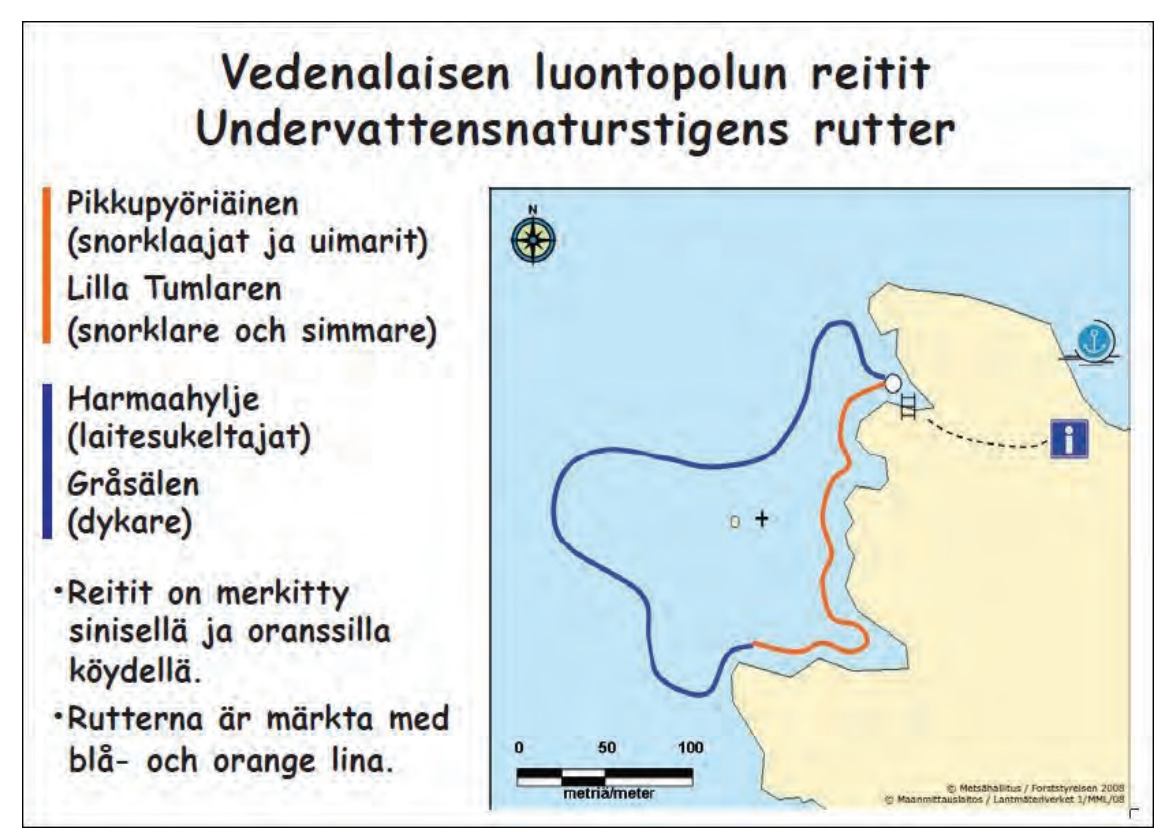

One of the info plates found at the beginning of the trail showing the two routes, orange for swimmers and snorkellers (little porpoises) and blue for divers (grey seals). Copyright: Metsähallitus.

Further, to increase diver interest, an artificial "wreck", comprising an old wooden rowing boat was sunk on the deepest part of the trail. This wreck had its own information plate and was held in place by adding stones.

It should be mentioned that the added complexity of the trail at Stora Hästö after 2008 meant a considerable increase in the amount of work involved in reassembling the trail before the start of the summer season in 2009. At the end of 2008, the shallowest information plates were moved to deeper water to avoid potential damage by sea ice during winter. In addition, the connecting ropes from both diving and snorkelling trails were removed.

On the first inspection dive of 2009, it was noticed that the wooden wreck had slid several metres down the gentle slope from where it was 
originally placed. Although the boat's keel had slid over the information plate, only minor damage was incurred, a testament to the good design. Trail reassembly involved moving the plates to their correct positions, reattaching the guide ropes and attaching an anchor to the wooden wreck to stop it from moving further. Overall, this work took two divers ten working days to complete.

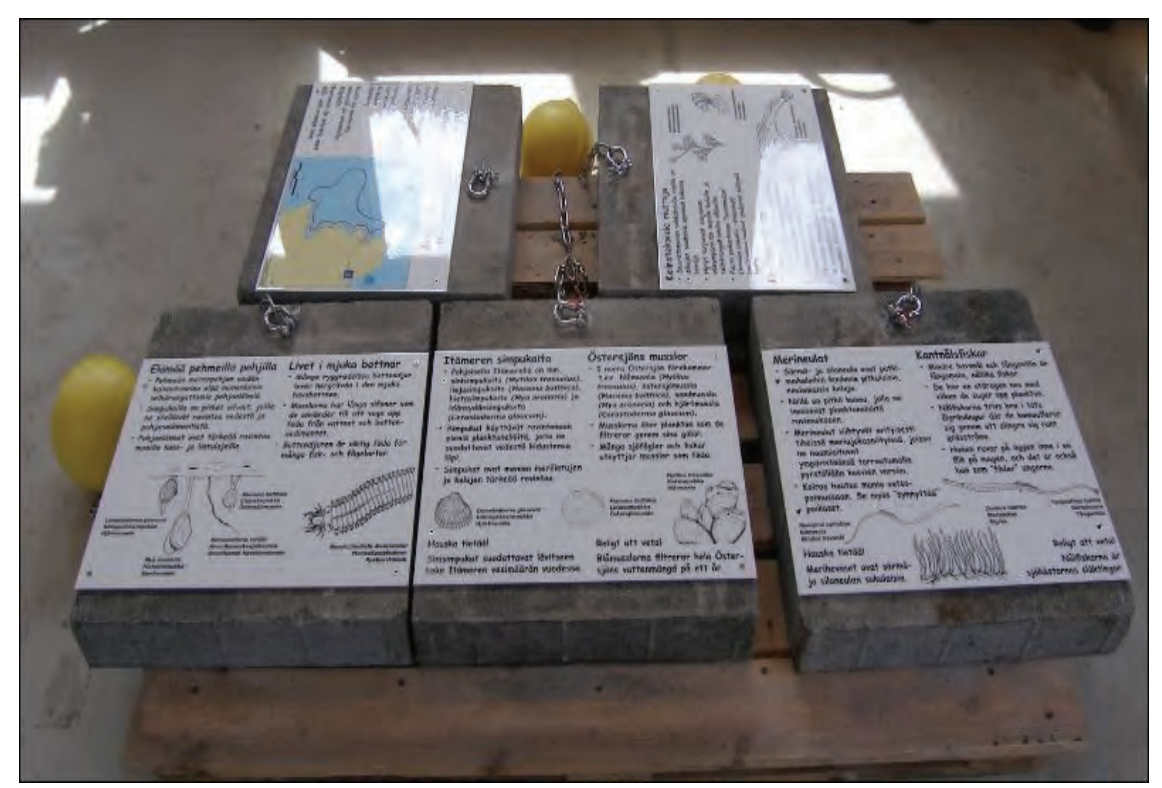

A selection of the information plates installed in Summer 2008. Note the use of colour and graphics to enhance their educational potential.

Photo: Heidi Arponen/Metsähallitus.

\subsubsection{Publicity}

- Magazine article: "What goes on beneath the waves" Text by Fran Weaver. Photos: Metsähallitus Appeared in " $60^{\circ}$ North- Natural Resources Magazine from Finland”. Issue No. 1, 2008. 3 pp. Online version available at: http://60north.mmm.fi/magazine

- Magazine article: “Märkänä Luontopolulla” Text (in Finnish) by Essi Keskinen. Photos: Metsähallitus. Appeared in the outdoor recreation magazine, "Retki”. Issue No. 5, June 2009. 2 pp

- Newspaper article: "Simpukkamatto johdatta sukeltaja meren pohjassa” Text (in Finnish) by Jaana Oksanen. Photos: Turun Sanomat. Published in Turun Sanomat 30.8.2008

- Newspaper article: "På stigen som för till en hemlig värld” Text (in Swedish) by Kim Lund. Photos: Kim Lund/ Åbo Underrätelser. Published in Åbo Underrätelser 30.8.2008.

\section{More information}

- Contact person: Conservation biologist Heidi Arponen (heidi.arponen@metsa.fi) 
- Archipelago National Park (www.outdoors.fi)

- Stora Hästö nature trail web page (in Finnish, www.luontoon.fi/saaristomeri)

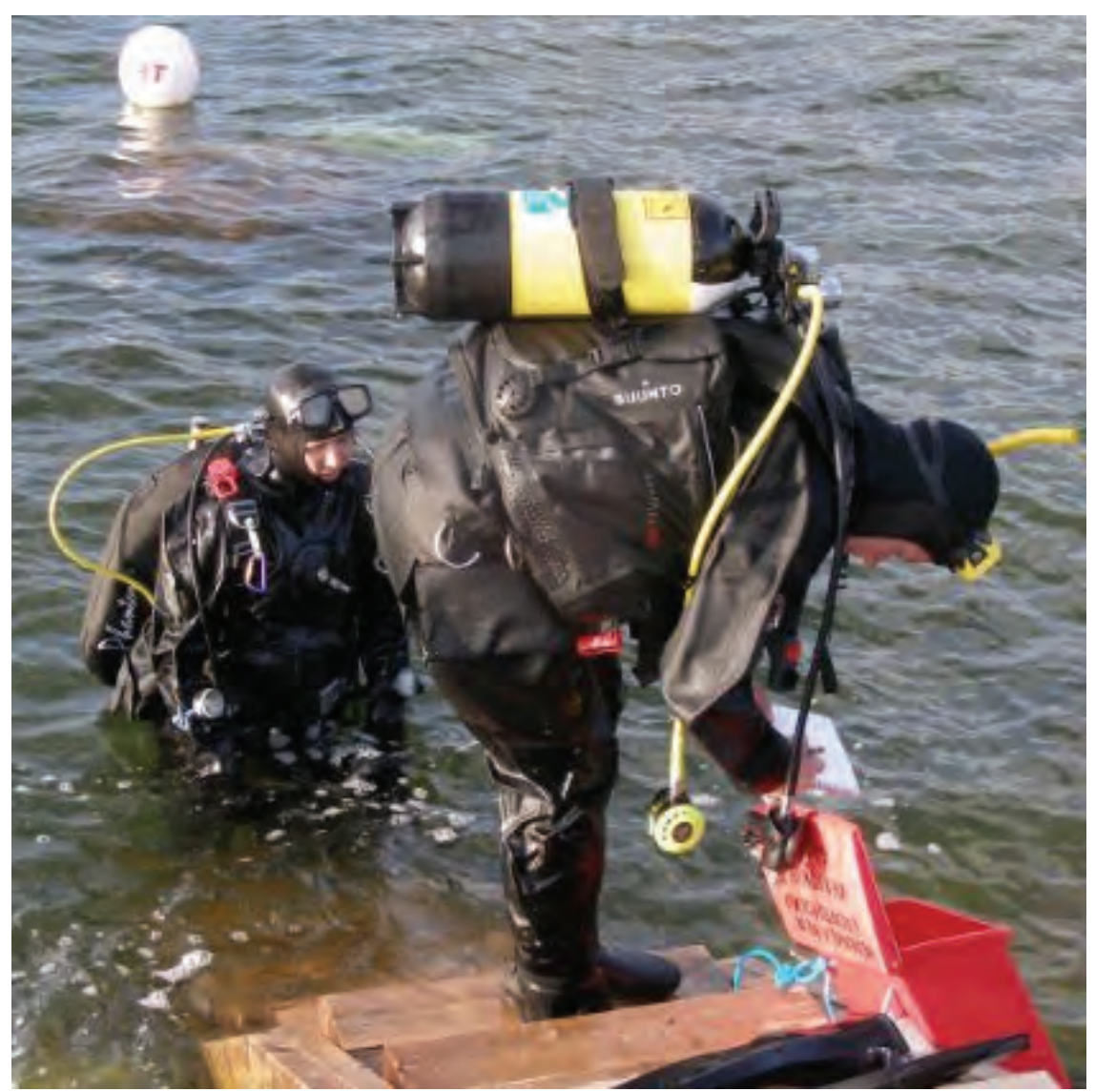

A diver examining an info plate in October 2008. Note the build up of blue mussels and algae on the buoy chain. Photo: Metsähallitus. 


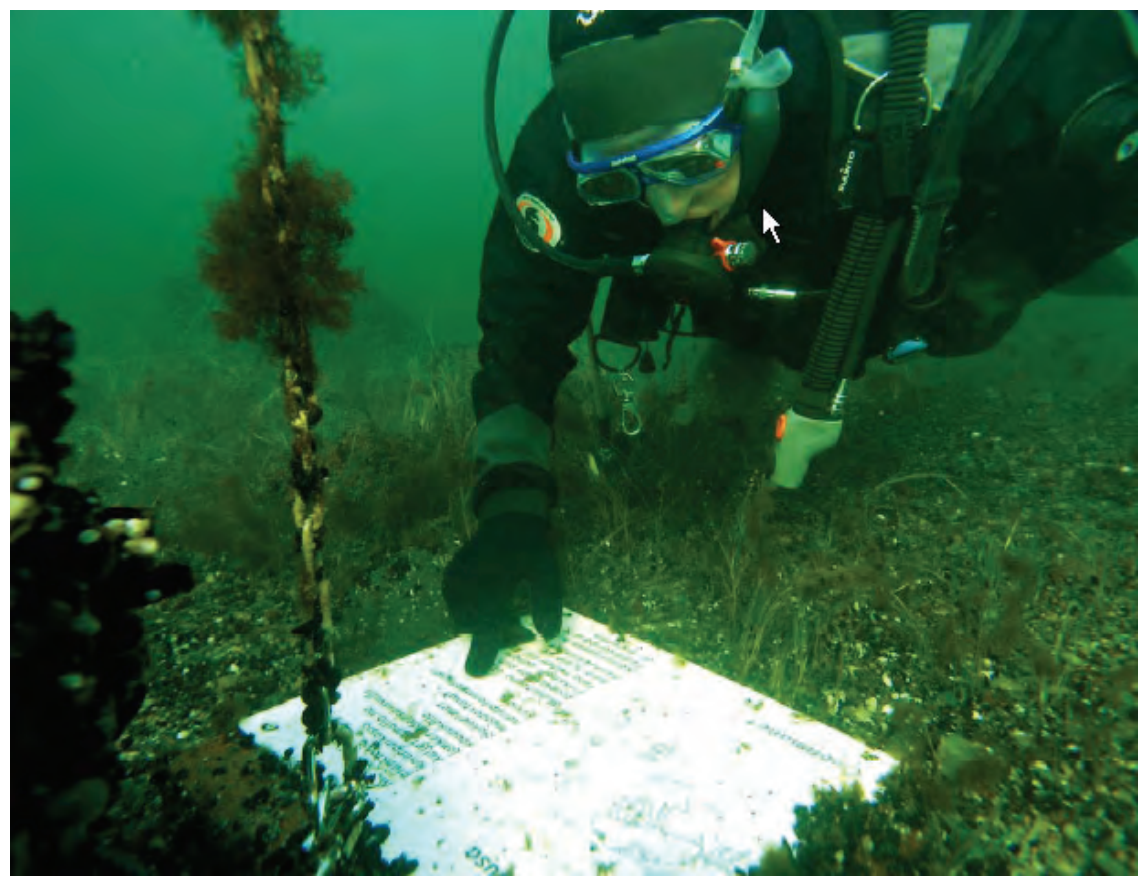

Divers emerging from the underwater trail can use the wooden steps and can leave their feedback on the waterproof guestbook. Note the white "Start" buoy in the background. Photo: Metsähallitus. 


\section{Chapter 3. Results}

\subsection{Work undertaken by the member countries in 2009}

\subsubsection{Finland - The Kronprins Gustaf Adolf Dive Park}

by Sallamaria Tikkanen, National Board of Antiquities, Maritime Archaeology Unit, Finland.

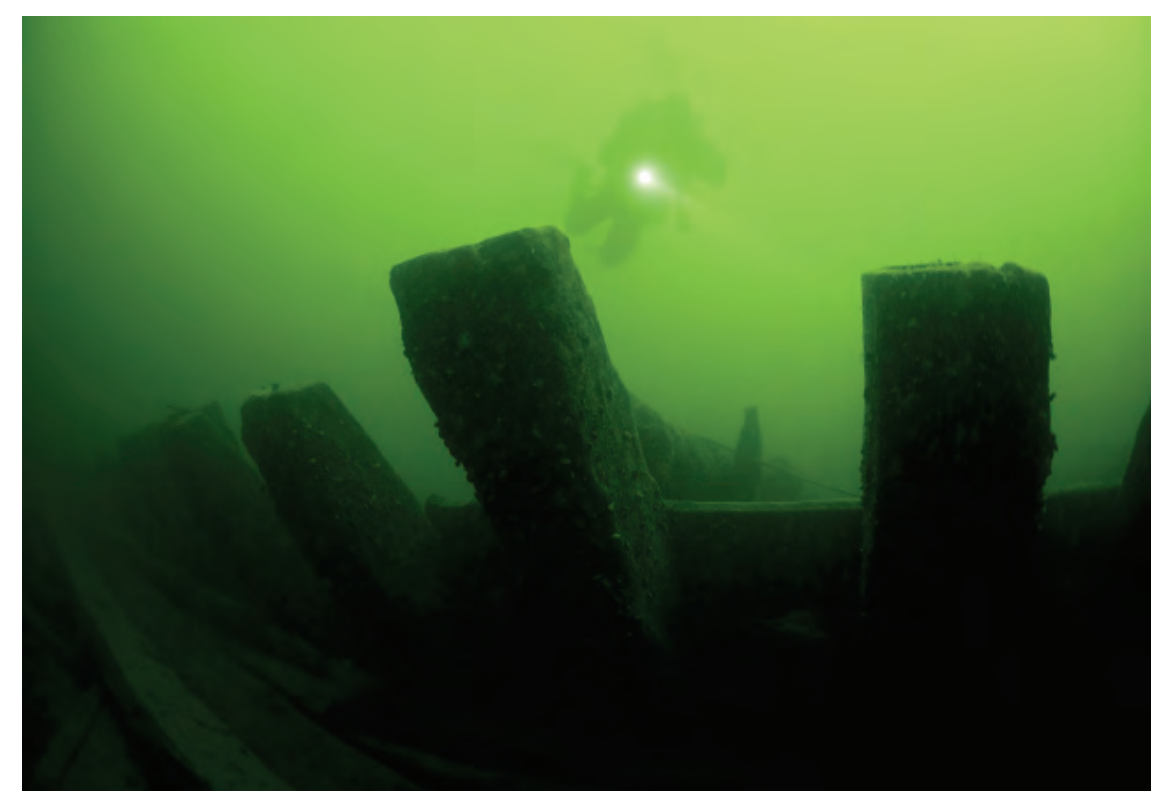

The timbers of Gustaf Adolf.

Photo: Pekka Tuuri/ National Board of Antiquities

\section{Project Work Packages}

All the main documents are in Finnish and English. More background information is available only in Finnish. All documents have been archived in the Archive of the Maritime Archaeology Unit.

\section{WP1: Suitable Site Analysis}

An Excel File called “Top Ten Possible Blue Parks Wrecks in Finland “ with various information (for example depth, type of vessel, fragility and visibility) has been produced and send to the Project leader. Location maps have also been produced. A Word Document explaining abovementioned information has been produced as a list of criteria for setting up an underwater park with explanations. The top ten new potential sites in Finland are: Keulakuva-wreck, Alfred, Sophia Maria, Jussarö II, Esselholm, Siiwo, Nordstierna, Punaparta-wreck, Fortuna and Mulan. 


\section{WP2: Pressure Evaluation Matrix}

An Excel File called "Possible Risks for the Wrecks in Finland" was produced and sent to the project leader, which included a list of different risk types (e.g. currents, sea ice, salinity and careless anchoring) have been listed. In addition, a Word Document called "Possible Risks Affecting Wrecks" has been produced. This document explains the different risk types in more detail.

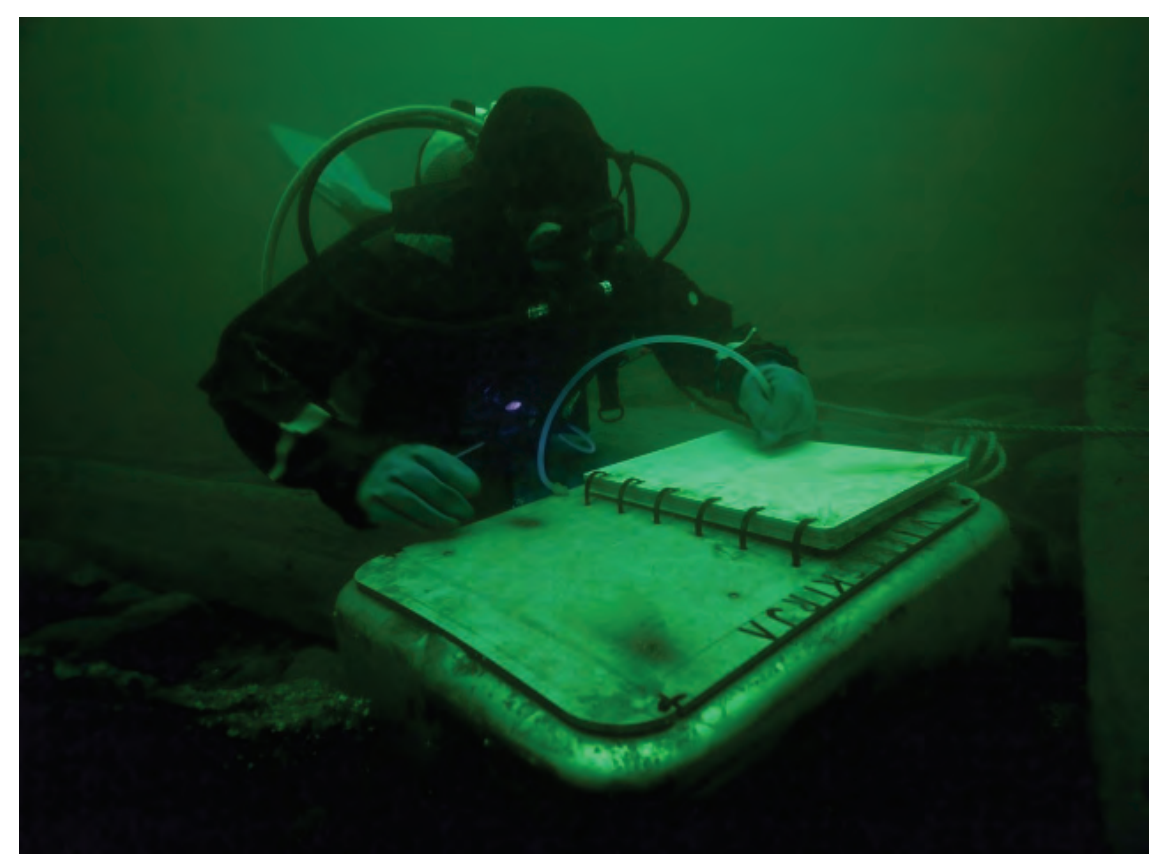

On-site equipment: an underwater guest book.

Photo: Pekka Tuuri/ Maritime Archaeology Unit.

\section{WP3: Guidelines and recommendations}

Before an archaeological/cultural site may be opened as an underwater park, it is important to first make decisions about how much information should be collected and the level of archaeological documentation required. Therefore, a document entitled, "Examples of documentation level and other measurements for underwater parks" has been produced and send to the Project leader.

Some guidelines/charters for general principles on this matter include:

- Convention on the protection of the underwater cultural heritage 2001. http://portal.unesco.org/en/ev.php-url id=13520\&url do=do topic\&url section $=201 . \mathrm{html}$

- Charter on the protection and management of underwater cultural heritage (1996). http://www.international.icomos.org/charters/ underwater_e.htm 
- The code of good practice for the management of the underwater cultural heritage in the Baltic Sea region (COPUCH). http:// mg.kpd.lt/LT/7/Underwater-Heritage.htm

While some guidelines/charters for Display and Interpretation are listed as follows:

- The international charter for the conservation and reservation of monuments and sites (The Venice Charter - 1964). http://www.international.icomos.org/charters/venice_e.htm

- The Nara document on authenticity (1994).

- http://www.international.icomos.org/charters/nara_e.htm

- The Quebec declaration. http://www.icomos.fi/GA16_Quebec_ Declaration_Final_EN.pdf

- The Xi'an declaration on the conservation of the setting of heritage structures, sites and areas. http://www.international.icomos.org/charters/ xian-declaration.pdf

- The ICOMOS charter for the interpretation and presentation of cultural heritage sites. http://www.international.icomos.org/charters/ interpretation_e.pdf

- The international cultural tourism charter (Managing Tourism at Places of Heritage Significance) 1999.

http://www.international.icomos.org/ charters/tourism_e.htm

Special developments and publicity

- A short report was written on the flora and fauna of the wreck following inspection of the wreck by a marine biologist. This has resulted in the creation of a new marine biology sign, which was installed on the wreck trail in 2010. In addition, more information about the biology of the site was displayed on the Internet Site in 2010.

- Twenty new underwater photos were purchased with full rights from Pekka Tuuri, an amateur photographer. These photos have been added to the archive of the Maritime Archaeology Unit. Seven of the new photos are on display on the Maritime Archaeology Unit Internet Site, http://www.nba.fi/en/mmf_park_photos

- A draft for the land-based information sign has been produced. The idea is to also erect two information signs on land, one on the Helsinki mainland at a point where it is possible to "see" the location of the wreck. Another land-based sign shall be erected in Suomenlinna. These signs were printed and erected in 2010, with a public event arranged for the general public. Incidentally, the 10th anniversary of the opening of the Kronprins Gustav Adolf Underwater Park was celebrated in 2010. 
- The site has been added to the Muinaispolut Internet Site and suitable material according to the Site style has been produced. The Muinaispolut Site describes Finnish archaeological paths in different parts of Finland. See www.muinaispolut.fi

- The Kronprins Gustav Adolf Underwater Park Internet Site has been updated (see http://www.nba.fi/fi/smm_puisto)

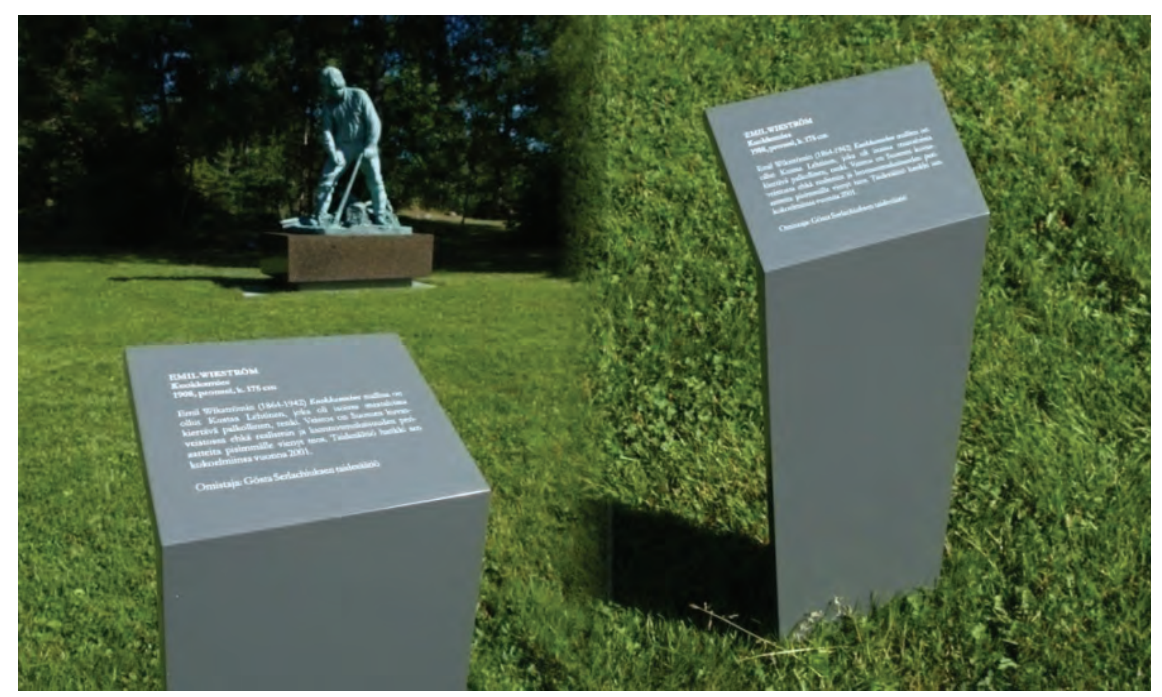

A photo showing the land-based information signs.

Photo: Finnish National Board of Antiquities

- The Swedish language version of the Kronprins Gustav Adolf Underwater Park Internet Site was opened at the end of 2009 (see http://www.nba.fi/sv/uvpark). Earlier there were only Finnish and English versions available.

- A new version of "Respect our Wrecks" in Finnish has been produced together with the PADI Finland organization. The material has been distributed for media in summer 2009. See: http://www.nba.fi/fi/ kunnioita_hylkyjamme_kampanja

- A lecture series concerning the Kronprins Gustav Adolf Underwater Park and the Nordic Blue Parks Project were given at various locations in Helsinki between May and October 2009.

- An article entitled ("Kronprins Gustav Adolf - Itämeren ensimmäinen vedenalainen puisto") was written by Salla Pärssinen, who worked for the Blue Parks Project and was published in the periodical "Albatrossi” (Merimieseläkekassan asiakaslehti 4/2009)

- An initial Short Exhibition Plan (Draft) has been developed and produced with the idea that the site shall be exhibited as one example of the many underwater cultural historical sites located at or nearby the Suomenlinna World Heritage Site. The concepts of underwater landscape and soundscape will also be introduced at this exhibition, which is planned for opening at the Suomenlinna Museum in 2011. 
- A “Landscape Underwater?"-seminar was organised on the 2nd of October 2009 in Helsinki at Kulttuuritalo by the Maritime Archaeology Unit, Metsähallitus, Turku University (Pori Unit, Landscape Studies), RAMSAR and ICOMOS Finland. The Kronprins Gustav Adolf was introduced as a case study. It was explained for example, that underwater landscape can be experienced with almost all the senses and that there are memories, stories and a spirit of place connected to the site.

Future ideas for the Kronprins Gustav Adolf

For divers

One way for divers to take part and share responsibility in safeguarding the site could be to encourage them to take monitoring photos/videos from certain visual monitoring points at the site selected by the Maritime Archaeology Unit.

For non-divers

This involves a special site trip aboard a suitable tourist boat so that the nondivers could "visit" the site via a ROV (remotely operated vehicle) submersible and onboard screen(s). This half day trip could also be linked with visits to interesting land-based sites, e.g. at Suomenlinna. However, this idea of guided underwater waterbus tours above the site appears to be more difficult to implement than expected. The primary reason is that normal sightseeing tour boats are not allowed to visit Kronprins Gustav Adolf site because it is located too far out on the open sea and the tour boats are not licensed by law to carry passengers under such conditions. However, it may be possible to rent a special boat for such tours or to apply for special permission (from the Finnish Maritime Administration) to be allowed to visit the site with the general public.

In 2010, we planned to produce an underwater video showing the entire underwater path and all the plates. This video footage will be displayed on the internet site. Other ideas which may be realised according to the available funding include:

- An interactive virtual animation showing the whole story of Kronprins Gustav Adolf.

- A popular coffee table book telling the story of the Kronprins Gustav Adolf, which will also be made available on DVD.

- Testing on-line cameras at the site and to make it possible to see the site on the Internet or at a museum exhibition.

- Producing a new updated version of the site material (brochure, diver's plastic map, www-site) in several languages; Finnish, Sweden, English and Russian. At present, this material is available only in Finnish, with only part of the texts in Swedish and English. The basic 
information on the Internet is available in Finnish, English and Swedish.

- To produce a permanent mini-exhibition for display at the Suomenlinna Information Centre.

- To produce an image of the site using multi-beam sonar images from the underwater landscape and the wreck, with a laser image from the nearest skerries. Thus, it will be possible to show under- and above water landscapes in one picture.

- To produce a marketing plan and to meet the local dive boat operators to improve the level of marketing.

\subsubsection{Finland - The Perämeri underwater nature trail in the Bay of} Bothnia

by Essi Keskinen, Metsähallitus.

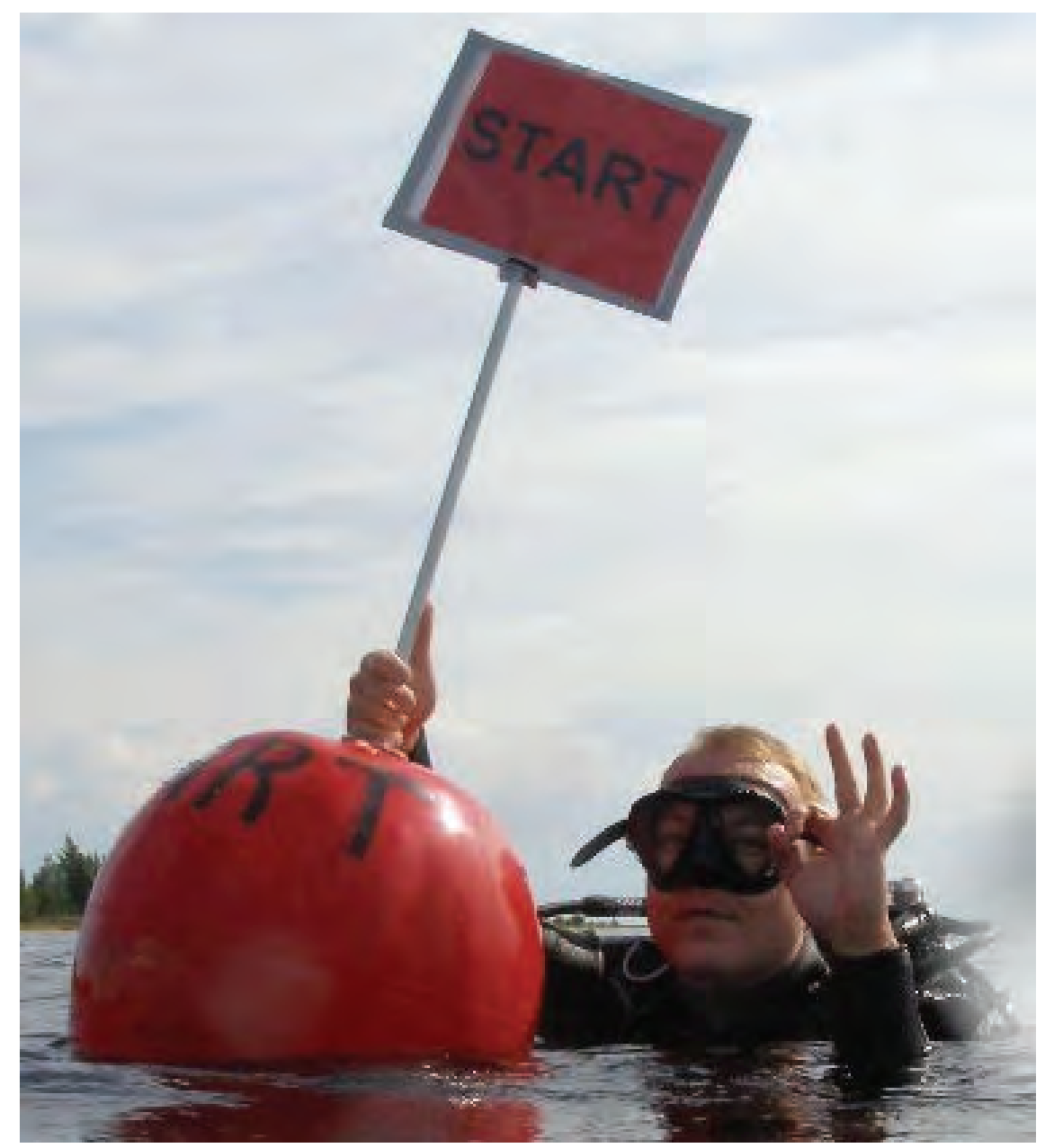

Start buoy marking the beginning of the Bothnian Bay underwater nature trail. Photo: Essi Keskinen/Metsähallitus 


\section{Background}

The first underwater nature trail in Finland was set up in 2006 by the Finnish Forestry Commission (Metsähallitus/Forststryelsen) in Korpoström, situated in the Archipelago Sea National Park. Since then, the trail has undergone improvements and received a steady stream of visitors during the summer months. Using this trail as a precedent, Metsähallitus decided to open a new trail in the Perämeri National Park in the Bay of Bothnia, in the northwestern corner of the Selkä-Sarvi archipelago. While the trail has been primarily designed for SCUBA divers with an interest in the underwater nature, culture and the marine biological work carried out in the Bay of Bothnia, it also offers a change from more traditional diving activities.

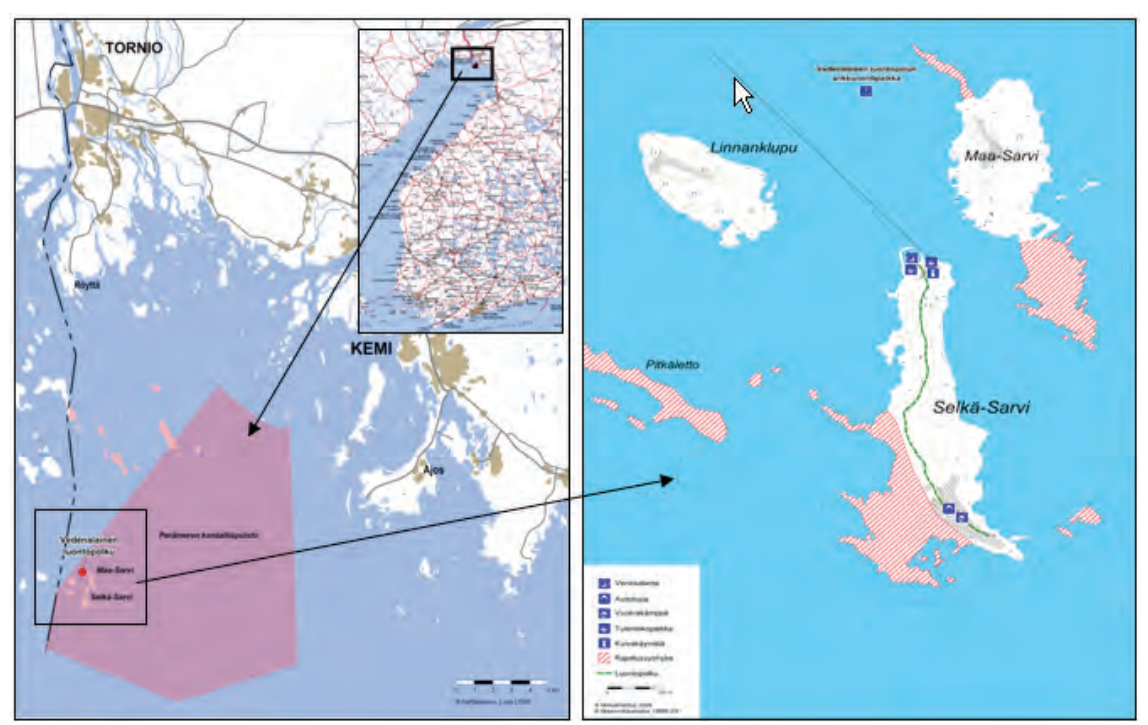

Maps showing the location of the National Park in the Bay Of Bothnia, as well as the position of the underwater nature trail near (blue square) the islands of Maa- and Selkäsarvi.

\section{Location}

Maasarvi is situated just north of Selkä-Sarvi harbour (N 65³6,9' W $\left.24^{\circ} 12,0^{\prime}\right)$, at the northernmost tip of which is found a bird sanctuary area. The underwater trail area represents the typical sub-aquatic world of the Bay of Bothnia, with soft bottom mussel communities, vascular plant meadows and rocky shoals swathed in water mosses. Snails and polyps are also to be found among the vascular plant communities.

\section{Safety issues}

Due to the proximity of the bird sanctuary area nearby, during the nesting period, i.e. between $1.5-31.7$, it is forbidden for boaters to either land in this area or approach closer than 100 metres. In addtition, to prevent anchors scarring the bottom and to protect the divers visiting the trail, it is forbidden to drop your anchor when you visit the underwater nature trail and you must use the mooring buoy provided. 


\section{Trail Construction}

The underwater plates were designed by a Master's Degree student from the Oulu University of Applied Sciences as part of her Master's thesis work. In addition, a large concrete weight was constructed to act as an anchor for a mooring buoy, as it is forbidden to anchor in or near the trail area.

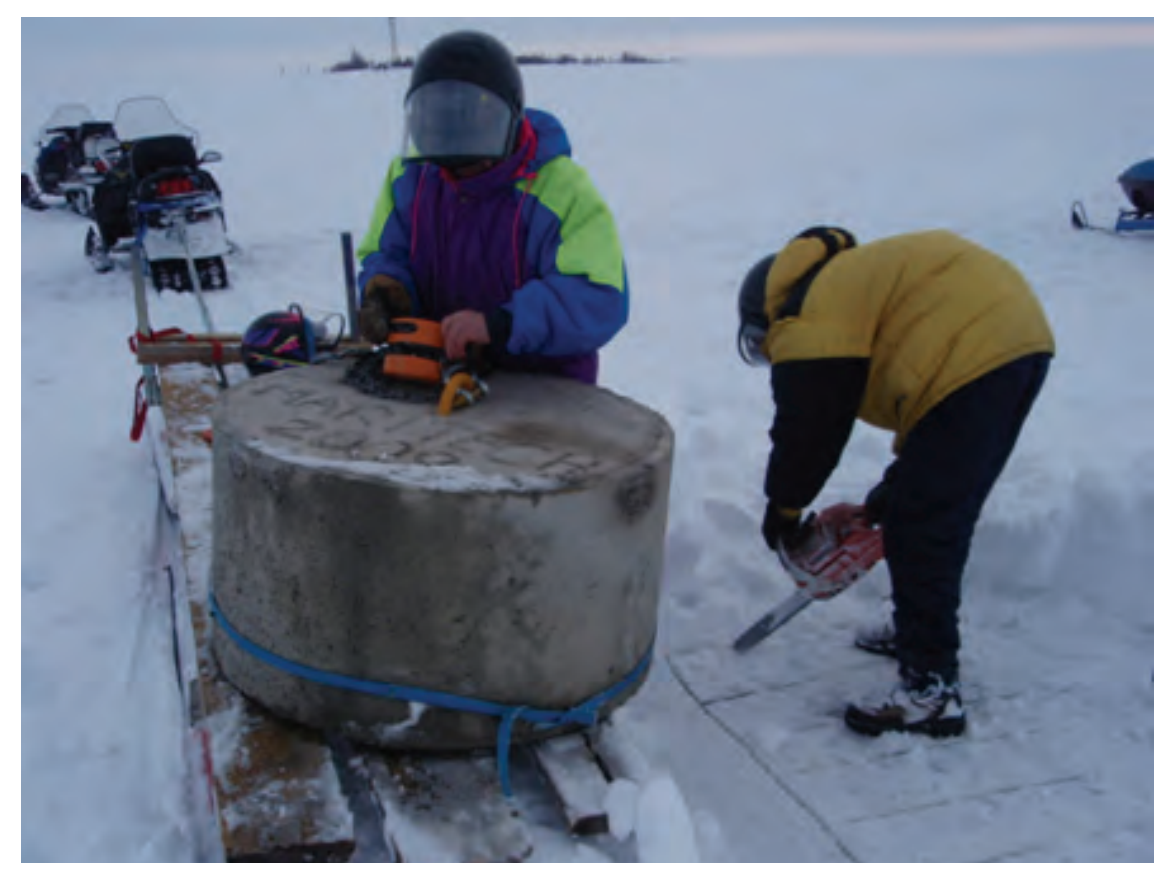

Cutting a hole in the ice to lower the concrete mooring buoy anchor.

Photo: Essi Keskinen/Metsähallitus.

Rather than buying prefabricated concrete slabs for the information plates, concrete was mixed and poured into moulds and allowed to set. These slabs are thicker and also have the advantage that stainless steel rings for the attachment of ropes can be embedded into the concrete before it sets hard. Pictures and texts were printed onto aluminium plates and these were attached to the concrete slabs. Due to its weight and relative difficulty to handle by boat, the mooring buoy anchor weight was placed on a trailer sledge and hauled by motor sled across the sea ice during the spring of 2009. A hole was cut in the ice and the weight dropped through. Once the ice had melted, the information plates were put in place by divers, using lifting bags: each plate was subsequently connected using carabiners and over 500 metres of rope. To help divers find the plates, red buoys were attached to each information plate using a length of stainless steel chain.

\section{Diving the trail}

To access the underwater trail, you must tie up your boat to the buoy provided on the western side of Maasarvi. The underwater trail lies only a short distance away and is clearly marked by a buoy marked "START". Swim along the surface to the start buoy, from which you descend to a depth of 
approximately six metres. The dive route is marked with a single rope to prevent divers becoming lost in case of poor visibility.

Along the trail are ten concrete plates from depths of one to six metres. Attached to these are information signs which present the endemic subaquatic flora and fauna, as some material about shipwrecks. In addition, divers can try out sampling gear used by scientific divers. This is a plate to which are attached stones and rocks of different sizes, as well as plastic plants which resemble the vascular plant species Myriophyllum (Fig. 20). The plate is surrounded by a square constructed from copper tubing. The diver is asked to make an estimate of the percentage cover and height of the "vegetation" and different-sized sediments. The correct answers are given underneath the information plate.

To make the dive even more interesting for visiting divers, a small fibreglass boat has been sunk as a "wreck" along the route in conjunction with a plate on shipwrecks in the Baltic Sea. The route is approximately 500 metres in length and returns to the start buoy, from which it is easy to ascend to the surface along the buoy rope provided. When diving on the trail, visitors are reminded to follow the safety guidelines outlined by Finnish Diving Association. Metsähallitus will not be held responsible in case of accidents occurring on the underwater trail.

The underwater nature trail was officially opened to the public on the 1st of August, 2009 and was featured in an article (with photos) in the newspaper, "Pohjolan Sanomat", as well as in the Finnish diving magazine, "Sukeltaja".

Additional facilities at the Selkä-Sarvi harbour include:

- a camping area for tents,

- two places for making camp fires,

- a rental cottage

- a wilderness hut

- fisherman’s village

as well as other interesting local features such as a sun dial, a navigational tower or day beacon (pooki) and a fishing hut (Ailinpeitin kalamaja), which dates from the 1860's. From the harbour on the southern tip of the island, a wooden walkway stretches about one kilometre through the uneven landscape to a fishing village.

\section{More information}

- Contact person: Marine biologist Essi Keskinen, e-mail:

Essi.Keskinen(at)metsa.fi

- Perämeren vedenalainen luontopolku (about the trail, in finnish, www.luontoon.fi)

- Perämeri National Park (www.outdoors.fi/peramerinp) 


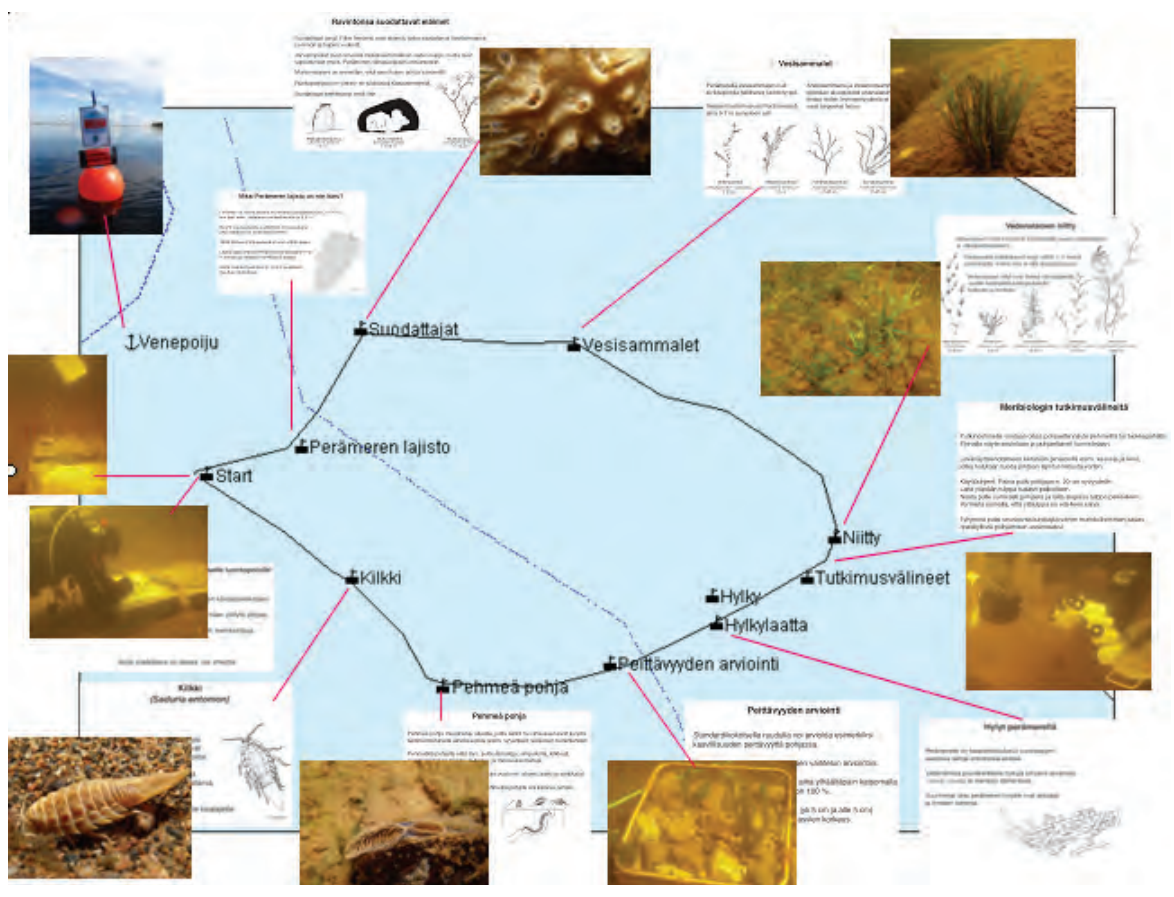

Map of the Perämeri National Park underwater trail, showing the start and finish positions, as well as the locations and information content of the various information plates. Copyright: Metsähallitus 


\subsubsection{Sweden - Nordic Blue Parks Sweden 2009}

By Pernilla Flyg, National Maritime Museum.

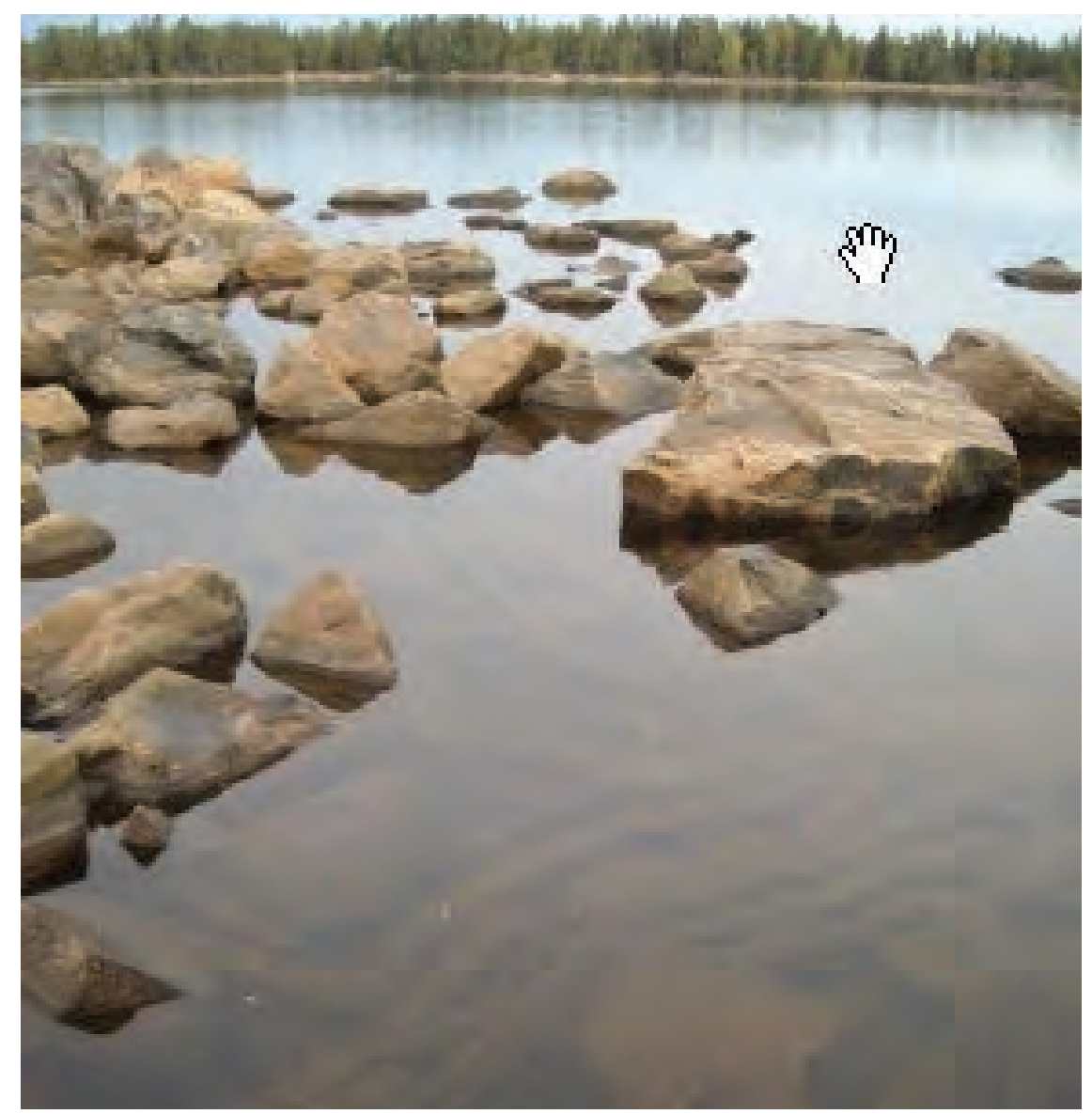

Some shipwrecks are visible and accessible even from land. When strolling along the shore, seeing the cultural heritage in the natural environment above and below the surface, you really sense the past in the present.

Photos: Pernilla Flyg, Maritime Museums.

\section{Summary}

The Blue Parks project in Sweden is a collaboration between the National Maritime Museums and the Environmental Protection Agency. The Blue Parks project is helping us to develop sustainable tourism, raise awareness, build local identity and increase accessibility.

During 2009 we have made preparations for opening an underwater trail in the Axmar area, north of Gävle, in 2010. Moreover, in the Dalarö area south east of Stockholm, we have taken a concept for sustainable, controlled access to protected shipwrecks many steps further. Finally, we have tested and developed underwater technology and methods for accessibility for nondivers. The various activities have rendered experiences that enable us to, in conjunction with experiences from the other project partners, outline guidelines on how to set up and manage a Blue Park. 
The Baltic Sea - history and present

The Baltic Sea of today is formed by the Ice Age. Submerged Stone Age settlements are remnants of a time when the coastlines of the region looked quite different from now. The Baltic Sea is an historic and archaeological treasure chamber where irreplaceable 17th century shipwrecks rest on the bottom. In an international perspective, this is a unique situation, provided by the inherent qualities of the Baltic Sea itself - low salinity, dark, shallow and cold water, slow water exchange, and the absence of shipworm and other wood-eating organisms in the major parts of the sea. Thanks to historical archives, we often know the stories behind the shipwrecks: the name of the ship, the name of the captain, where it was going and what happened when it sank.

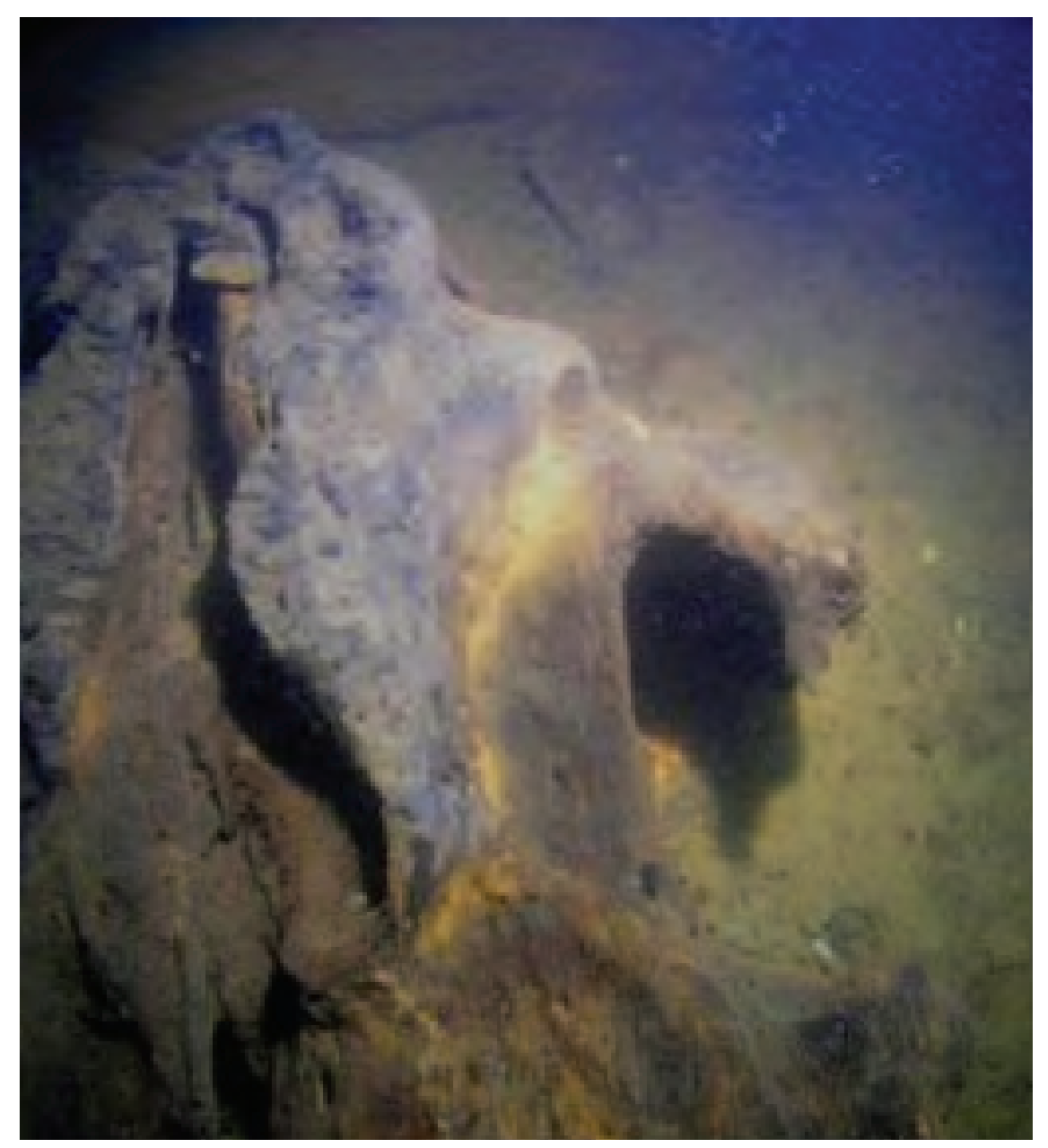

The lion figurehead of the 17th century Dalarö Wreck. Photo: Jens Lindström, Maritime Museums.

The stories often have a local connection and attract local interest. Even those shipwrecks whose origins are unknown to us can also tell us much about historic times, since organic artifacts are preserved over the centuries. Once on the bottom, the shipwreck often turns into an artificial reef, a habi- 
tat for plants and animals. It is not unusual to discover that various parts of a shipwreck have become a habitat for solitary fish. Nevertheless, the underwater natural and cultural resources are under constant threat from pollution, deterioration, and insufficient or lacking legal protection.

\section{Blue Parks - creating sustainable accessibility}

One way to diminish this threat is by creating awareness through a developed, sustainable marine tourism that combines outreach with protection. The public will benefit from a visit to a Blue Park, where they will be introduced to an environment they are not familiar with, and receive a personal experience. A Blue Park can help build local identity ("my place") and raise awareness ("our sea"). The environment and heritage will benefit from it, since a Blue Park provides a geographically confined or otherwise controlled way of informing the public of the threats towards, and wonders of the ecosystem and the historic remains. The Swedish part of the Blue Park project involves two areas: the Axmar Ironworks area north of Gävle, and the Dalarö area southeast of Stockholm.

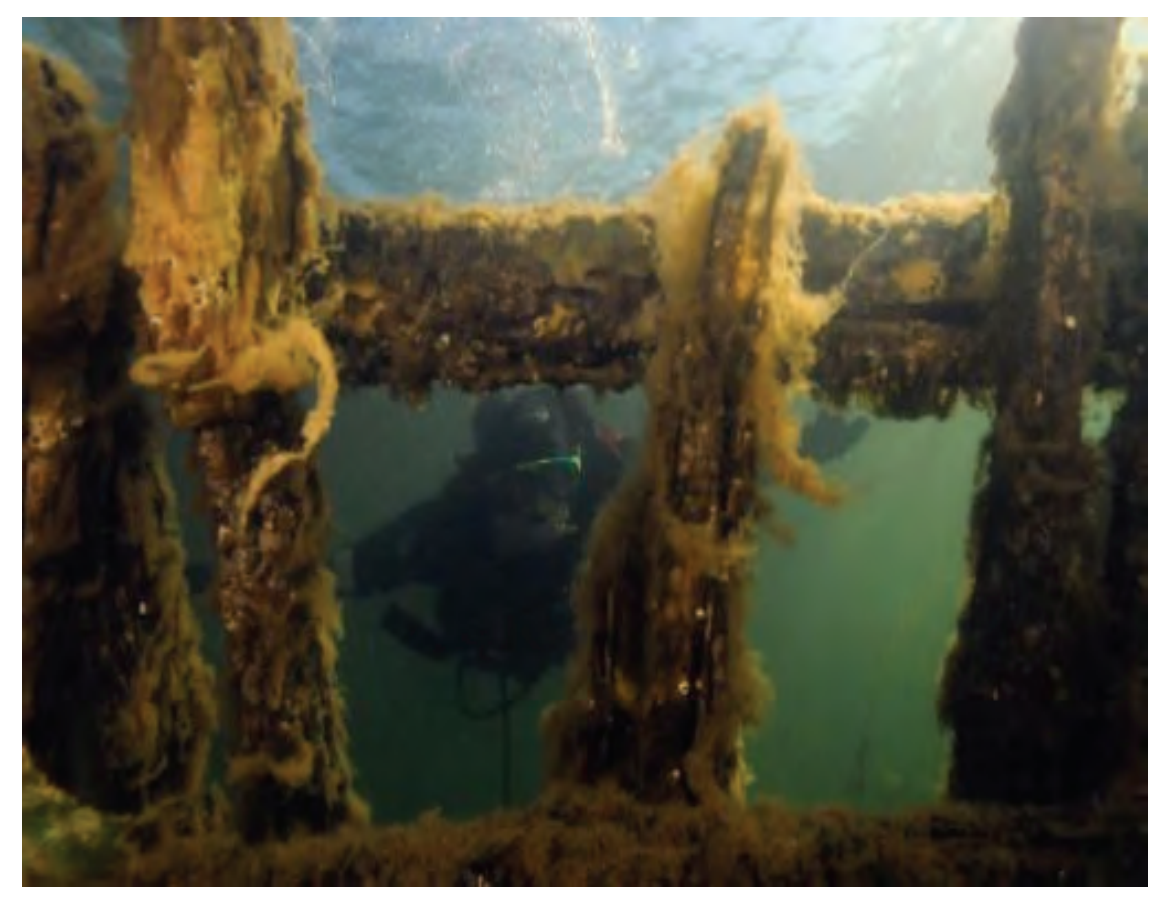

An archaeologist from Gävleborg Regional Museum by the shipwreck of "The Patriot" in Axmar.

Photo: Jim Hansson, Maritime Museums.

\subsubsection{The Axmar Underwater Trail}

The 17th century iron works at Axmar by the coast north of Gävle is part of the industrial heritage of Sweden. The waters outside the Axmar iron works are crowded with shipwrecks and constructions related to the local iron works industry and trade. During archaeological fieldwork performed in 
2006, around 30 sites and monuments were recorded, among them several shipwrecks (Ekberg et al. 2007). The oldest shipwreck in the area is dated to 1588, almost 100 years previous to the founding of the iron works in 1671 . The Axmar iron works was closed in 1927, mainly because of the landlift that made the sailing routes and the harbour too shallow. The area will become a culture reserve during 2011.

The Axmar archipelago is relatively unaffected by environmentally harmful activities and settlements. The area was appointed as a nature reserve in 1978 and is today also acknowledged as a Natura 2000 site and Baltic Sea Protected Area (BSPA). The Axmar nature reserve protects a biologically interesting area with a wide variety of different habitats.

Several different water habitats are found in the nature reserve. The sea is relatively shallow with an abundance of stones, boulders and shoals. The proximity to the outlet of Ljusnan and all the small rivers which flows into the archipelago creates a substantial freshwater influence on the area, resulting in a mixture of marine and freshwater species. The sea area at Axmar is important as spawning ground and nursery for many species.

The sea bed areas with soft substrate constitute a perfect habitat for Charales and vascular plants. The species found among the Charales are mainly rough stonewort (Chara aspera) but also Baltic stonewort (Chara baltica) and bird's nest stonewort (Tolypella nidifica) while the most abundant vascular plants are horned pondweed (Zannichellia palustris), fennel pondweed (Potamogeton pectinatus) and Eurasian water milfoil (Myriophyllum spicatum). These species generally prefer calmer waters.

Relatively species-rich macroalgal communities are growing on the hard substratum as well as on the many shipwrecks found in the area. The algae are mainly dominated by filamentous algae, although occasional Phyllophora/Coccotylus sp. and Furcellaria lumbricalis and scattered Fucus species are found. The dominating red algae are Polysiphonia fucoides, Ceramium tenuicorne and Polysiphonia fibrillosa. The most common brown algae are Sphacelaria arctica and Ectocarpus/Pylaiella sp. while the green algae Cladophora glomerata and Enteromorpha sp. dominate on shallow substrates. Both bladderwrack (Fucus vesiculosus) and Fucus radicans grow in the area and constitute important breeding and foraging habitats for many species of fish and other animals. The dominating species among the marine animals are barnacles (Balanus improvisus) but cnidarians (Hydrozoa) and blue mussels (Mytilus edulis) are also abundant. The freshwater fungus Ephydatia fluviatilis is sometimes found on large boulders. On the sea floor the isopod Saduria entomon and the red-listed eelpout (Zoarces viviparous; NT) are found. Both the isopod and the eelpout are glacial relicts, which dispersed to the Baltic pool at the end of the last ice age. Some common fish in the area are perch (Perca fluviatilis), pike (Esox lucius), common minnow (Phoxinus phoxinus) and stickleback (Gasterosteidae). The grey seal is the only marine mammal found in the area. The Axmar nature reserve is an excellent refuge for repre- 
sentative plants and animals of the southern coasts of the Gulf of Bothnian Sea coast.

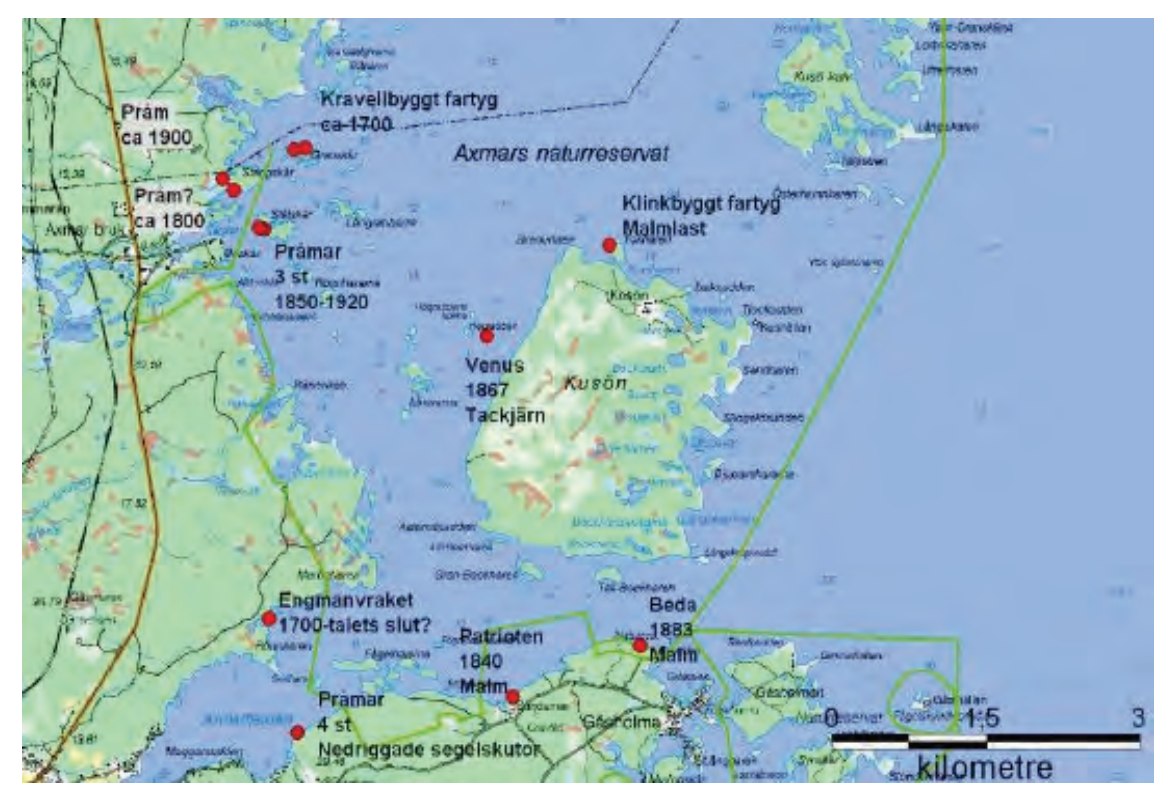

The red dots represent interesting shipwrecks within and in the vicinity of the nature protection area of Axmar.

Due to the relatively rapid land uplift (70 centimeters/100 years), you find primeval forest on the islands, and shipwrecks are exposed just below the water surface, visible from boats and sometimes from land. Apart from easily accessible underwater natural and cultural attractions, the old harbour warehouse has a very popular restaurant attracting between 40,000 to 60,000 visitors every year (http://www.axmarbrygga.se/).

The local and regional authorities, regional university college, local population, community association, local and regional press and business are informed, involved and very positive to the project. We have for instance been contacted by entrepreneurs who would like to start dive tours and canoe/kayak-rental services in the area. During the summer and autumn of 2009 we explored the area during two periods of fieldwork. The fieldwork was performed by staff from the National Maritime Museums, the Gävleborg Regional Museum, and a nature environment consultant. The main purposes of the fieldworks were to survey of the area, sketch the first Blue Trail, and produce a decision support for the presentation of the information in the Blue Park. The Axmar Blue Trail is planned to be opened to the public in summer 2010. The report of the fieldwork was published in January 2010 and is available online at the following web address:

http://www.nordicblueparks.com/web_documents/slutredovisning marina_natur-_och_kulturv_rden_kring_axmar_bruk.pdf 


\subsubsection{The Dalarö Dive Park}

The Dalarö archipelago southeast of Stockholm contains a great number of well-preserved shipwrecks from the 17th and 18th centuries. The waters off Dalarö are a traditional hot spot for scuba divers. Each year, 1500-2000 divers are estimated to visit the area.

One negative aspect of the popularity is the many incidents of looting. There is also continuous low-intensive destruction through wear, and as a result, diving has been prohibited on some of the shipwrecks. Luckily, a solution to this problem is under way. The National Maritime Museums have developed a model (The Dalarö Model) envisioning a wreck-diving park which will enable controlled access to protected shipwrecks.

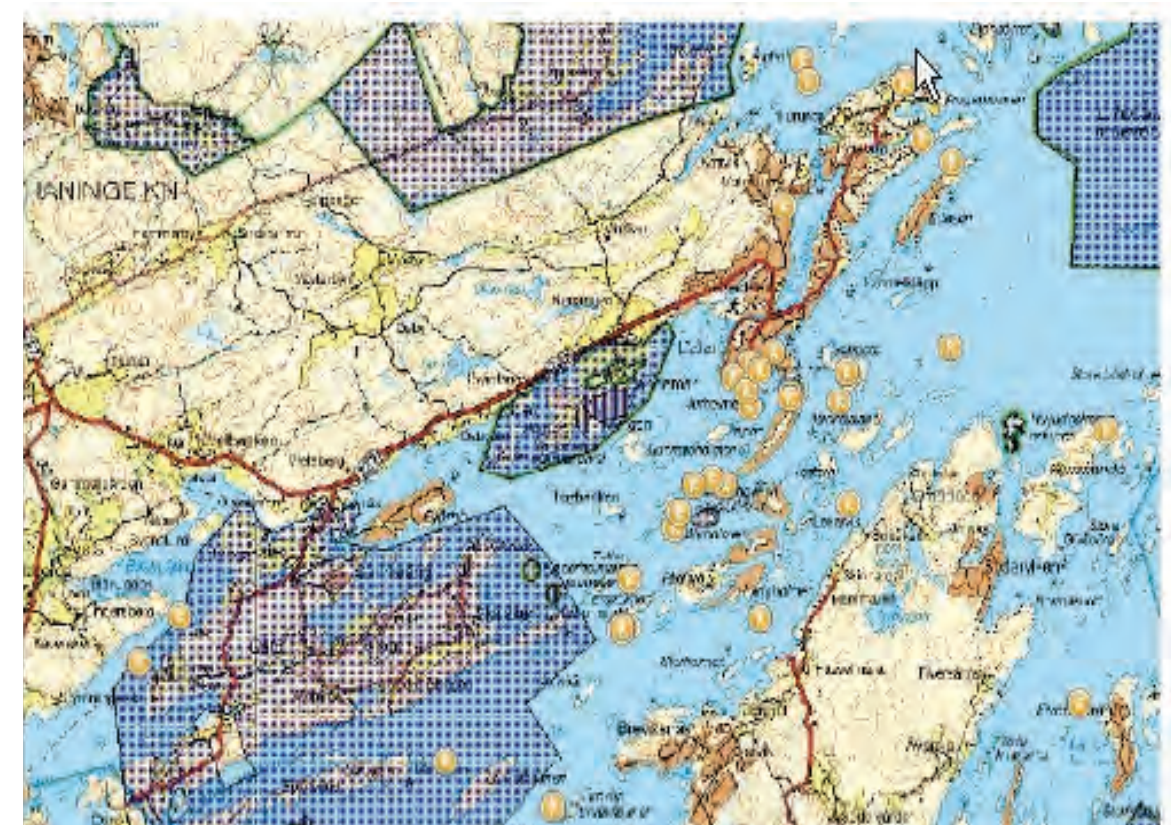

This map shows the number of registered shipwrecks (orange dots) in the Dalarö region. The hatched zones are nature protection areas. Excerpt from Fornsök, the national web-based public register of sites and monuments at the National Heritage Board.

This concept addresses both divers and non-divers. Divers will get permission to dive on the wrecks when accompanied by a licensed guide, who shall have relevant competence and training to be able to educate the divers on the cultural heritage of the area and the shipwrecks. This will increase professionalism as well as business opportunities among dive charter companies operating in the area.

In order to implement the Dalarö Model, a collaboration group has been formed. This group consists of representatives from the National Maritime Museums, the National Heritage Board, the Stockholm County Administrative Board and the Local Authority of Haninge. The major task of this group is to, within a two year pilot study, implement the Dalarö model and enable the Dalarö Dive Park. 
During 2009, we used the Dalarö area to perform initial tests of techniques and methods for controlled access to protected shipwrecks (Activity 1), and diving for non-divers (Activity 2).

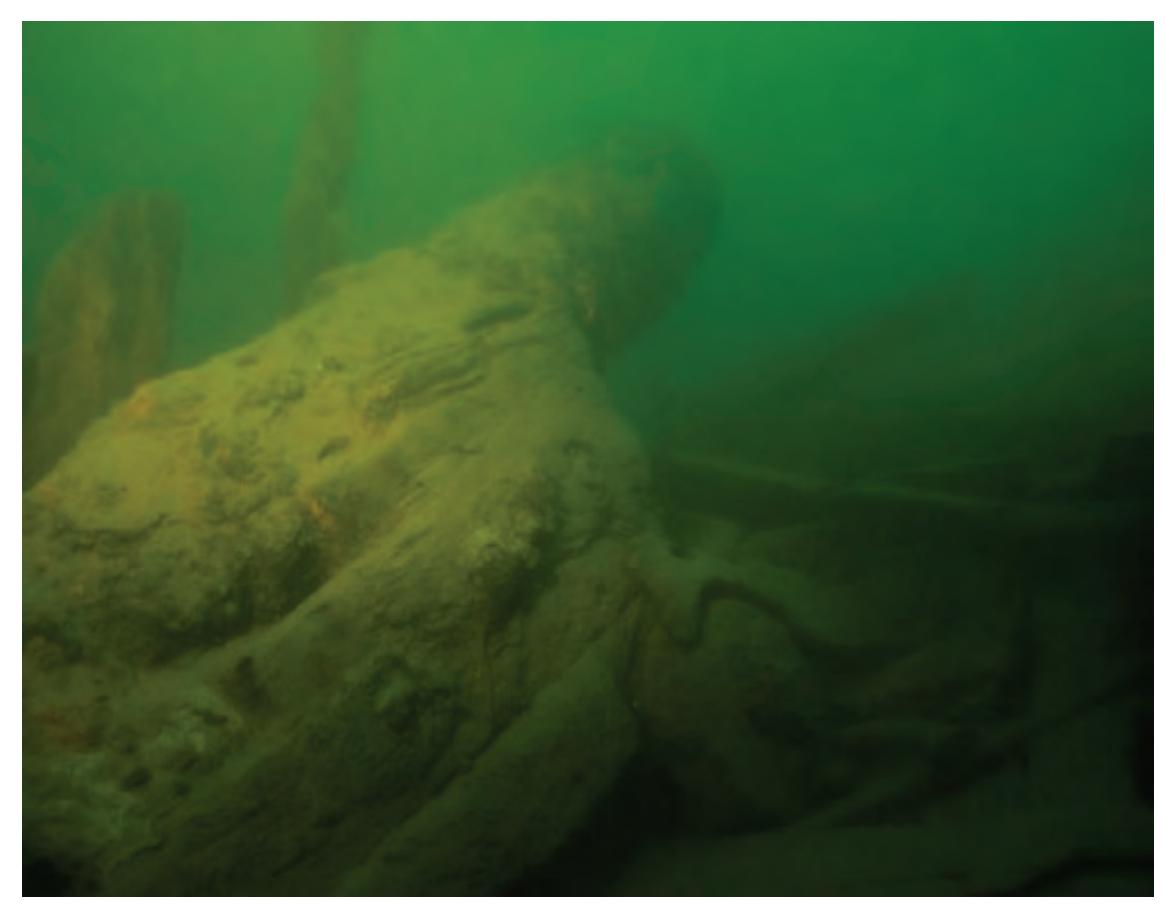

A cannon ready to be fired on the deck of the 17th century "Dalarö Wreck".

Photo: Jens Londström. Maritime Museums.

\section{Activity 1: Culture-historical diving}

In July 2009, special permissions were provided by the County Administrative Board in Stockholm to allow access to a shipwreck off Jutholmen in Dalarö where diving normally is prohibited. The reason for this exeption was to allow testing of "culture-historical diving". We hired a dive charter company, posted an announcement on the diving community (www.dykarna.nu) and invited experienced divers to apply for permission. Together with the dive charter company we selected a total of eight divers. The test included onboard education and information about wreckdiving, and about the history of the area and the shipwreck itself. When we arrived to the site, slates (Fig. 28) were distributed and the divers went in, two by two. After the dive, the divers filled in a survey questionnaire. The test divers now form a reference group of sports divers who will help us develop the concept further.

The general outcome of the test and the survey was that the divers were very satisfied. They appreciated the pre-dive information and the slates and they believed divers would be willing to pay extra for culture-historical diving. There is a very good potential for dive tour companies who are willing to become more professional and offer this kind specially guided tours, particularly if they include the international market. 


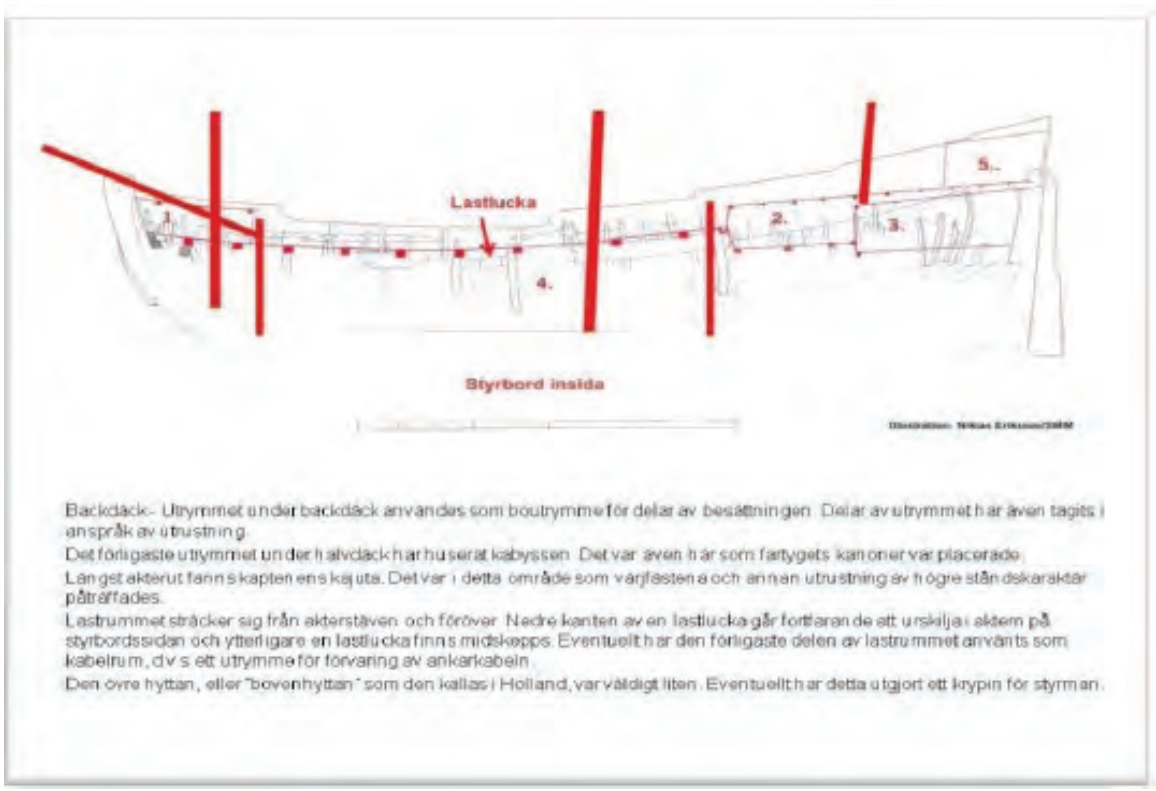

A plastic slate is easy to bring along underwater!

Photo: Maritime Museums

Activity 2: Underwater experiences for non-divers

A ROV (Remote operated vehicle) is a mini-submarine equipped with a camera. It is operated from on board a boat or from land. Everything the ROV "sees" is displayed on a screen on board. When you watch the screen, particularly if you pilot the ROV yourself, you feel that you "almost dive". If you combine the visual input with narrative (e.g. "What's the story behind this shipwreck?”), then the experience becomes richer. During the 2009 Blue Parks project, we have tested and evaluated ROV technology and usability.

Piloting an ROV is a very exciting experience but it requires a lot of practice. If you want to use an ROV in order to entertain and engage tourists you also need good lightning. While we believe that underwater experiences for non-divers has a very good potential to become a big tourist attraction, we still need to perform tests with the tourism industry and selected groups of tourists to make the best of this concept. 


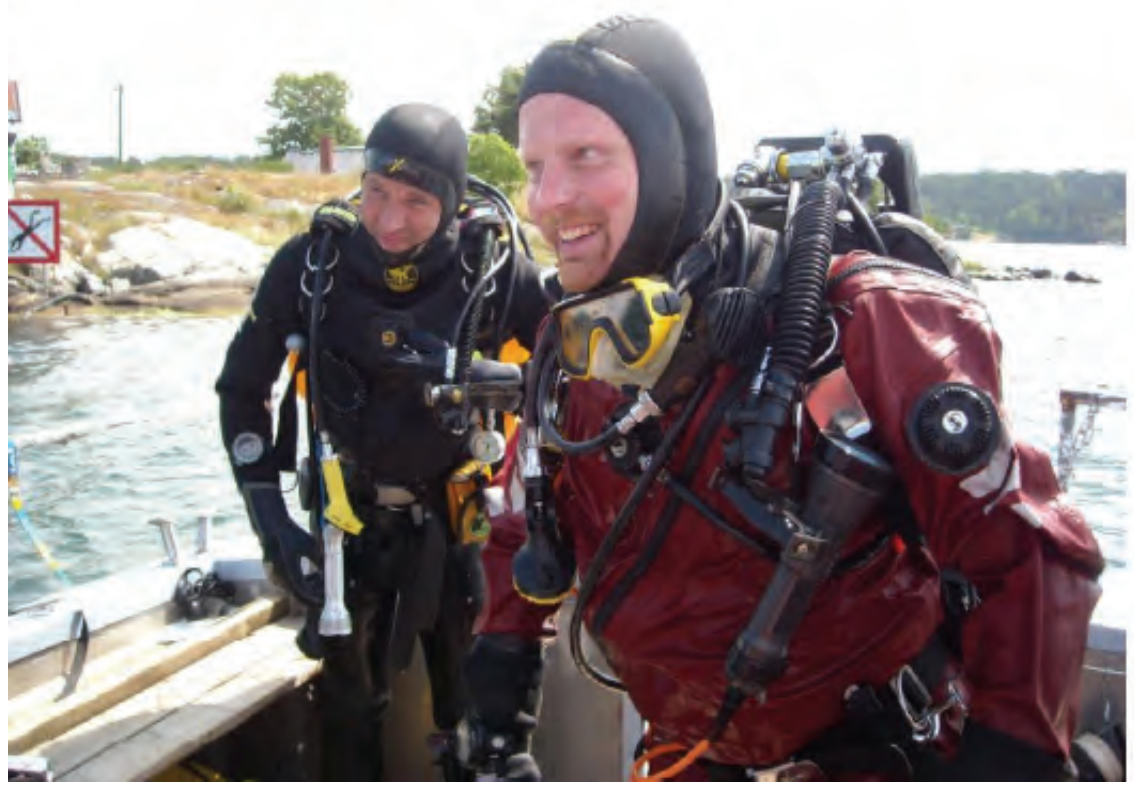

Happy divers after a dive on a protected 18th century shipwreck just off Jutholmen in Dalarö. Note the diving prohibited sign in the background!

Photo: Pernilla Flyg, Maritime Museums.
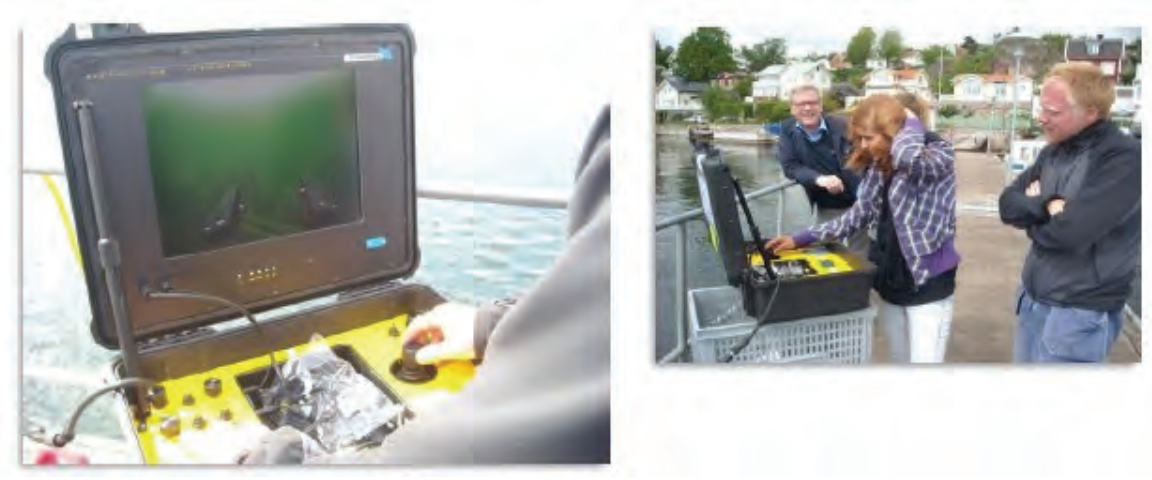

During the ROV-testing in Dalarö on the shipwreck of the 18th century flute ship Anna Maria, we had a visit from the Dalarö tourist office.

Photo: Pernilla Flyg, Maritime Museums.

International examples of underwater experiences for non-divers

While most underwater trails and parks abroad are made for divers, a few examples of underwater adventures for non-divers also exist:

- ROV-trips for tourists in Orkney (http://www.rovingeye.co.uk/)

- ROV-trips for tourists in Vermont, USA (http://www.shipwrecktour.com/)

- Glass-bottom boats in Skye, Scotland (http://www.seaprobeatlantis.com/)

- Glass-bottom boats in Michigan, USA (http://www.shipwrecktours.com/) 
- Shipwreck trails with markers and signposts on land in Australia (http:// www.warrnamboolinfo.com.au/pages/shipwreck-trail-great-ocean-road/)

\section{Involving people}

Every place has a story. Sometimes there is a lot of local awareness, for instance in the form of a local community association or interest group. If there is no involvement, or perhaps even reluctance towards this kind of project, it is important to attempt to create a "buzz", include the ideas of the critical parties, thereby creating a sense of "my place and our sea".

It is also important to strive to empower private/regional/local actors to take over the management and responsibility of the Blue Parks and to facilitate the setting up of new Blue Parks. This may be done by providing:

- Lists of funds and resources

- Structures for marketing and development plans

- Sets of best practices and guidelines

- Ideas and material for stakeholder meetings

The following are good examples of activities and strategies the Swedish partners involved in the Nordic Blue Parks project have used to create involvement.

\section{Network with stakeholders}

Hold meetings where you invite the local populace, entrepreneurs, tourist office, historic community associations, etc. Support, involve and allow them to be active/responsible for exhibitions, putting up signposts, monitoring and care-taking (buoys, jetties, concrete slabs, signposts etc). Keep stakeholders updated via e-mail and the internet. During the two fieldworks at Axmar, we had a blog where we reported daily events and published photos. (http://www.sjohistoriska.se/amnen/marinarkeologi/marinarkeologerna_ blogg.aspx )

- Support local entrepreneurs and let them take active roles. For example, canoe-rental and dive-tour companies planning to open activities in the Axmar area in 2010. The National Maritime Museums (NMM) and Gävleborg Regional Museum will become part of a reference group.

- In Dalarö, NMM will collaborate with a dive tour company which helped develop the concept of "culture-historical diving". We are also involved with the local tourist office and have meetings and ongoing discussions with entrepreneurs planning dive centres.

- Contact and stay in touch with (local) media. Media are extremely interested in anything that involves diving, archaeology, shipwrecks, or indeed almost anything underwater! It is vital to take advantage of such interest! 


\section{Make a marketing and development plan}

A marketing and development plan shall have an exit strategy for the initial partners (government agencies and local and regional authorities) and a plan for the transferring of the Blue Park into the hands of entrepreneurs and other NGOs. The plan should be strategic and flexible and it should answer relevant questions. The following are examples of pertinent questions relating to the plan for marketing and development:

- What is the purpose of marketing? Do we wish to attract a continuously growing group of returning visitors to the site or to create business opportunities for local service providers?

- How shall it be done? Through the attractive presentation of events and experiences and/or to use surveys in conjunction with census data to show commercial potential.

- Who is the target audience? Families within X kilometres from the site.

- What are the marketing tools available? These include:

- Websites and weblinks

- Invitations to the national and local press to write about the project/the specific sites

- Attracting specialist magazines and lifestyle magazines,

- Involving local/regional politicians and cooperate with local service providers

- Holding workshops with focus groups representing various tourism categories (accommodation, food, activities etc).

- What is the unique selling point (USP)? For example, "Hands-on natural and cultural heritage experiences in fantastic surroundings and the best pub in the area within paddling-distance!”.

Create strategic collaboration groups

- Multi-lateral collaboration: The Dalarö Dive Park project is complex since it involves complicated legal issues regarding dive-prohibited shipwrecks and accessibility. To deal with this, a collaboration group was created with representatives from National Maritime Museums, National Heritage Board, Stockholm Country Administrative Board, and Local Authority in Haninge. The group has regular meetings, dedicated areas of responsibility and a common timeline.

- Triple-helix collaboration: recurring strategic discussions with, and presentations/lectures at the Södertörn University College, School of Life Sciences, Department of Tourism studies, in connection with rural tourism entrepreneurs.

- Cross-sector collaboration: Axmar Blue Park is a collaboration between the Environmental Protection Agency, the National Maritime Museums, the Regional Museum of Gävleborg, a natural environment consultant, and the Gävleborg County Administrative Board. Local stakeholders are invited to meetings. 
New Blue Parks in Sweden?

The Nordic Blue Parks project has rendered a lot of attention and there are requests from various partners and regions who would like to establish their own Blue Parks.

- Blekinge Archipelago and coast is a UNESCO MAB Biosphere Candidate Area with very high cultural and biological values, including a submerged forest.

- Kosterhavet National Park, Sweden’s first marine national park.

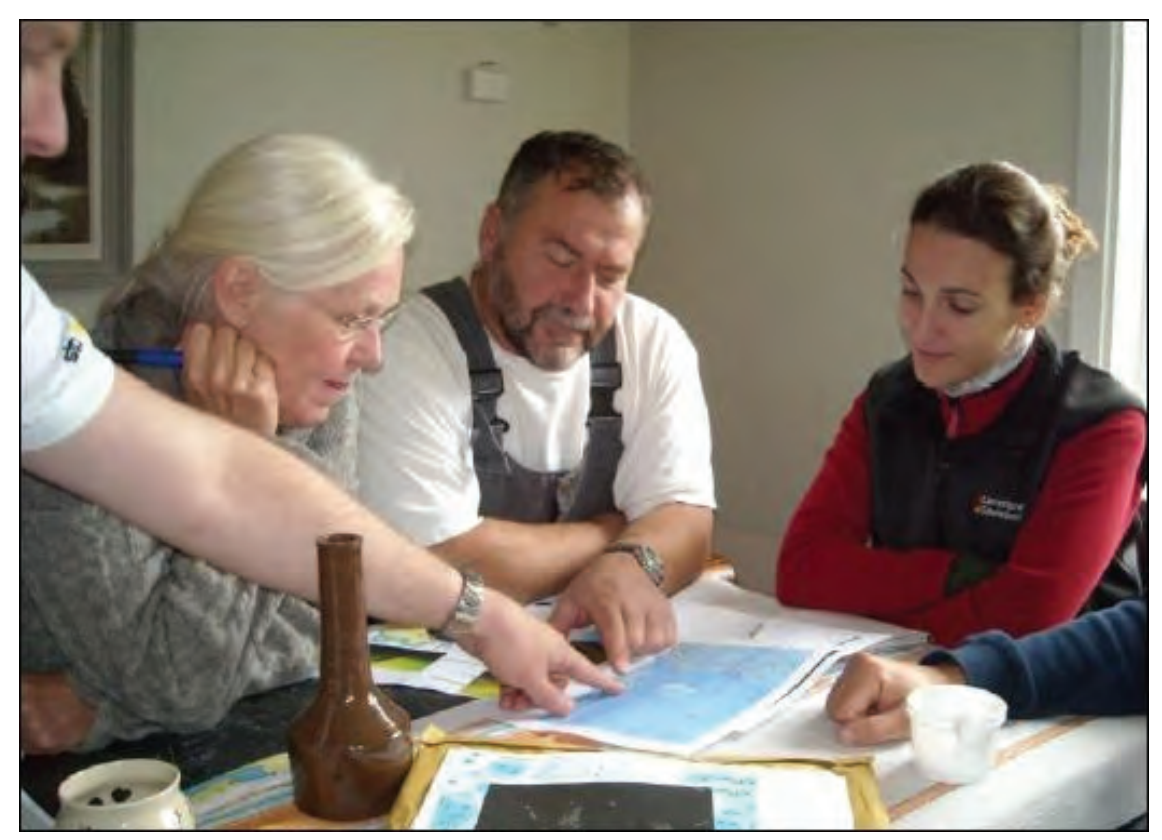

Project group meeting at the Axmar iron Works café, run by the local historical community association.

Photo: Maritime Museums

A GIS-study performed during 2009 in conjunction with the Nordic Blue Parks project (Flyg et al. unpublished report), combining cultural heritage data with nature reserves, Natura 2000 and habitat areas show that there are plenty of areas along the Swedish coast that could be suitable for Blue Parks.

Further information is available from a pre-study investigation carried out jointly by the Swedish Environmental Protection Agency, National Heritage Board and National Maritime Museums. In this report, the national Maritime Museums compiled a list of valuable submarine cultural heritage sites and mapped how they coincide with nature protection areas (Swedish Environmental Protection Agency pre-study report No. 5566, 2007). 


\subsubsection{Denmark - Report on the Højklint Blue Trail}

By Otto Uldum, Langelands Museum.

\section{Background}

Langelands Museum was invited as the Danish partner in the joint Nordic project "Nordic Blue Parks", supported by the Nordic Council of Ministers. This happened rather late in the course of events and a meeting was held in June 2009, with the participation of Kevin O’Brien (Metsähallitus, Finland), Else Marie Stamphøj (By- og Landskabsstyrelsen, Denmark and Otto Uldum (Langelands Museum, Denmark). It soon became clear that the trail envisaged by By- og Landskabsstyrelsen would not come into being, due to lack of time, but that Langelands Museum would join the project, and make time, even if this meant that the trail would be constructed at the very end of the project period.

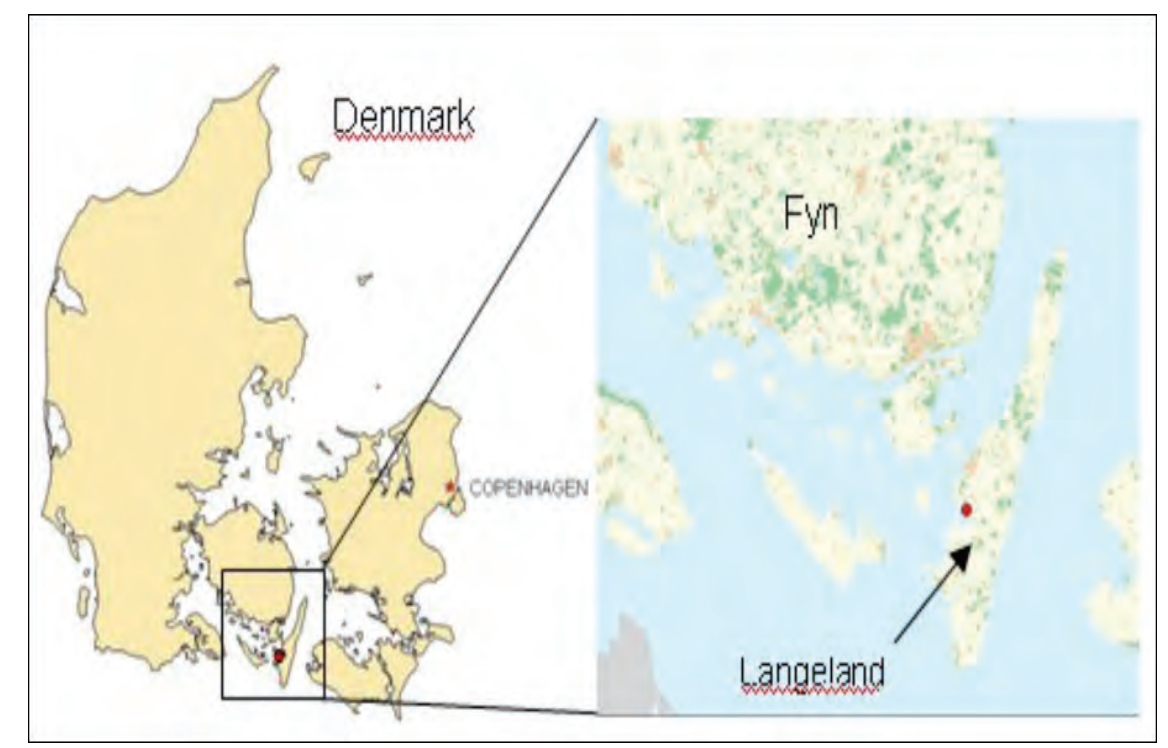

Denmark with the trail site marked by a red dot (left). The Strynø Basin with Lindelse Nor and Højklint (right).

\section{Location \& History}

When Langelands Museum was invited to join the project, no obvious site to create a Blue Trail sprang to mind, but it was clear that our contribution was to be the story about the submerged Stone Age landscapes in the waters around Southern Fyn (Funen). Due to the rise in sea level when the ice cap melted at the end of the last ice age, about 13,000 year ago, in combination with land movements, large areas now under water, were dry during the early and middle parts of the Scandinavian Stone Age, right up to the point of neolithisation, ca. 4000 BC. The present Archipelago of Southern Fyn, offers unique conditions in terms of preservation of these landscapes, because of its sheltered waters and flat glacial geomorphology. A large number 
of submerged Stone Age sites have been identified, with some excavated to various degrees.

Underwater topography has been used as a means to spot the sites where fishing would have been plentiful in the Mesolithic and this has resulted in many new sties. Langelands Museum has employed mapping of the seabed with the aid of seismic sub-bottom profilers, in combination with coring, which has revealed the existence of the Strynø-basin, a large now submerged bog and lake area, between the islands of Ærø, Strynø and Langeland. Lying at depths of up to 5 metres, covered only by a thin layer of sand, this fossil freshwater environment offers large areas of Stone Age soil surface, with tree stumps and fallen trunks from the Stone Age forest. This also contains a large number of settlement sites.

In order to choose a suitable location for a Blue Trail, several aspects were taken into consideration:

- Accessibility

- Quality in terms of objects to see

- Archaeological vulnerability

- Diving safety

Lindelse Nor, an inlet on the west coast of Langeland was initially considered because of its sheltered waters and location as part of the Strynø-basin. Unfortunately it is surrounded by farmland, and few roads leads to its shores. Only one public road leads all the way to the beach, so a trail here would be the obvious solution. The area was thoroughly dived as part of the museums' annual cruise with amateur divers with an interest in maritime archaeology, which occurred in the first week of September 2009. Along the sandy cliff of Højklint ("high cliff"), a number of tree trunks and stumps were discovered, as well as some patches of seabed without vegetation, where worked flint was found. Coring revealed a layer of peat at least 1 metre thick under the sandy layer (ca. $15 \mathrm{~cm}$ ), which had clearly accumulated in fresh water conditions, prior to the sea level transgression. This made the site as good a place as any to experience the fossil Stone Age forest, combined with the possibility to find contemporary artefacts. 


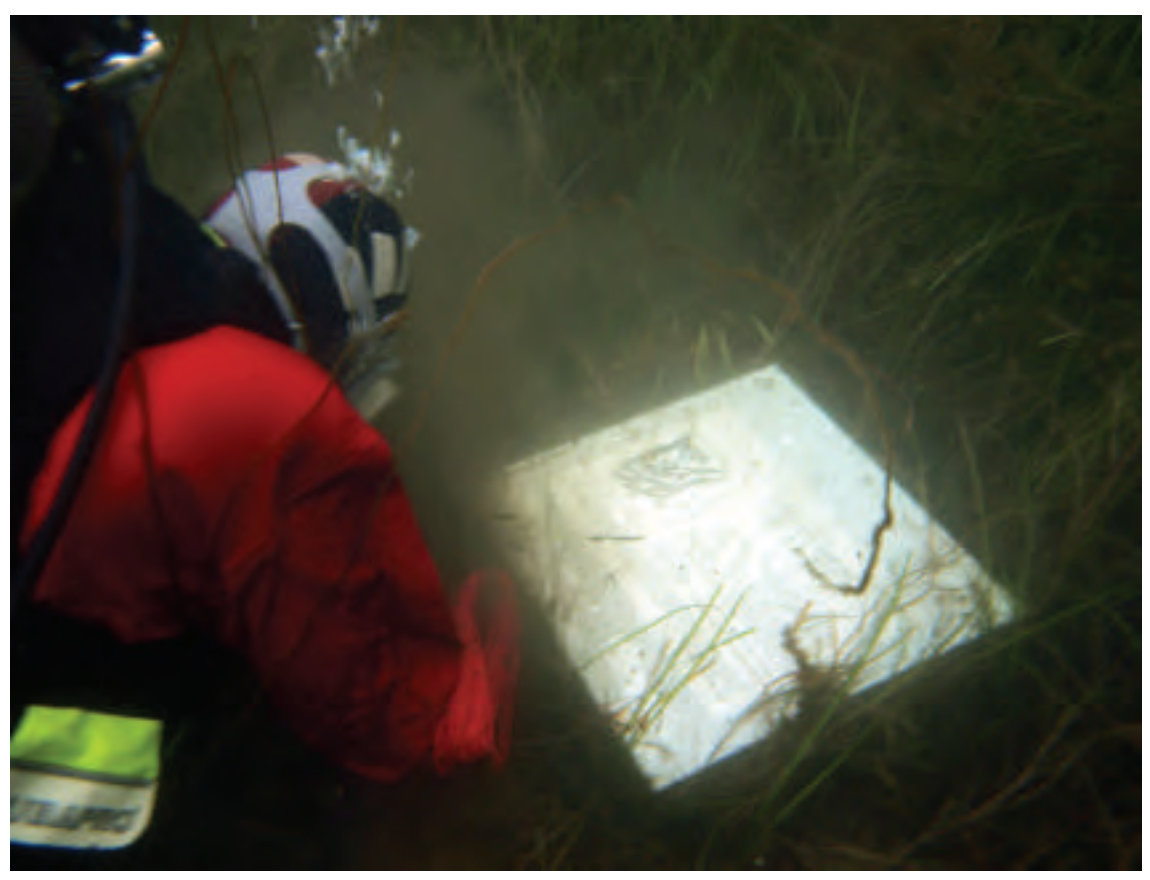

A diver arranges one of the slabs on the sea bed.

Photo: Langelands Museum

The question of archaeological vulnerability was soon be answered with a "Let's do it!" Our primary concern lay with preservation aspects with regards to cultural history and here the area dominated by eelgrass with patches of exposed seabed did not facilitate the large scale collection of artefacts. The occasional taking of worked pieces of flint already washed out of the sediment as souvenirs will not threaten the future possibilities for archaeological research in the area.

The trail is accessible by car with a small car park servicing the owners of the dinghies moored along the beach. From here it's a short walk on the beach with dive gear and from the foot of the cliff, there's a 50 metre swim to the first white marker buoy, attached to station 1 on the trail. These sheltered waters are calm in all weather conditions and maximum depth on the trail is three metres. Visibility is good and there are no soft, loose sediments to disturb. Water currents are very limited. This all makes for a safe and easy dive, which could be easily used for training purposes.

\section{Trail construction}

From the rough list of themes for the stations, seven were distilled and posters were made with texts and illustrations. Although visibility and lighting conditions are usually excellent on the site, it was decided not to use colour. The font used is 16 point Verdana, which seems to work well under water, allowing for a reasonable amount of text and illustrations in a nice large format. The trail consists of seven stations, each with a text explaining either a subject from the archaeological or the natural history perspective. Illustrations are in greyscale and the graphic lay-out was done "in- house”, using Adobe In- 
Design printed via a PDF file. This makes it easy to edit and renew the individual posters. The information posters were printed on A3 sheets of PVC-foil on a common office laser printer. The infopoints were constructed from concrete garden slabs $(50 \times 50 \mathrm{~cm})$ to which were attached two slates of polycarbonate fixed with 8 screws of A4 steel. The poster was placed between the slates.

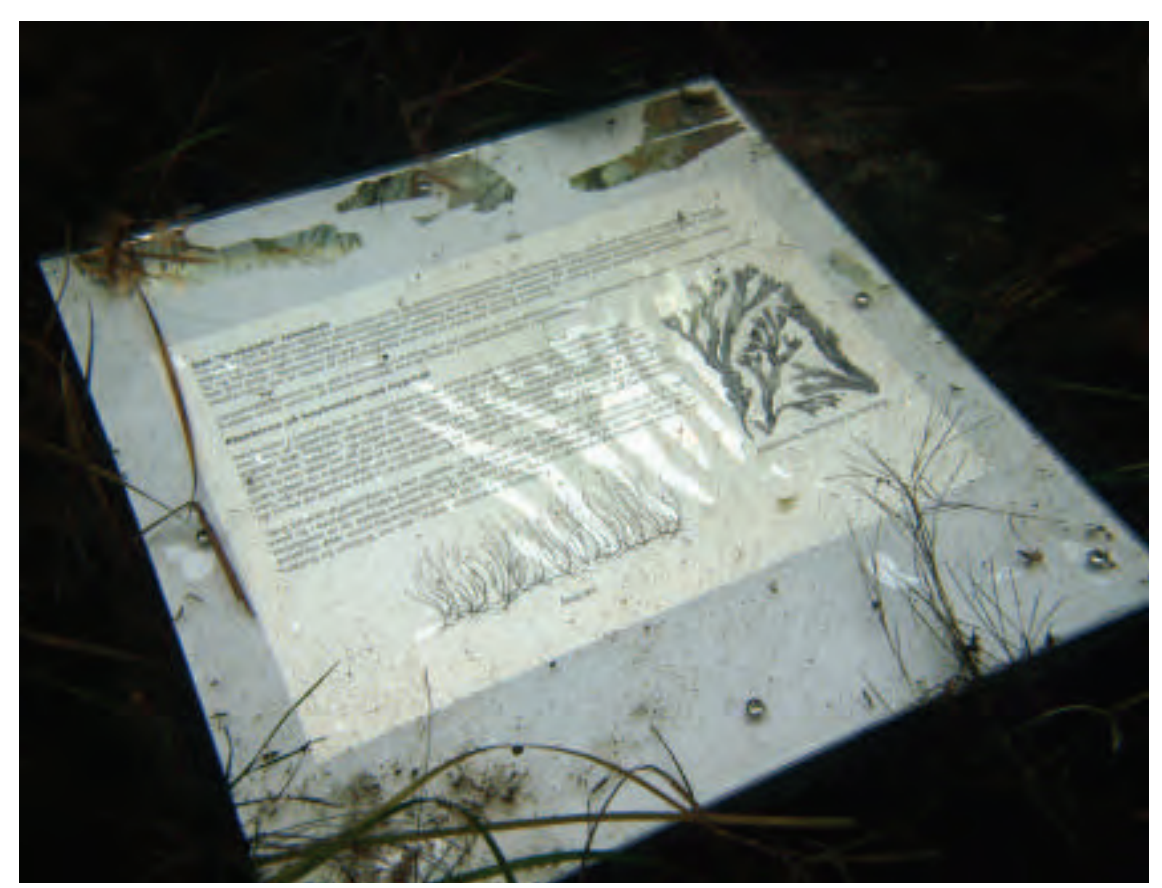

One of the slabs in situ, the A3 PVC foil is sandwiched between two polycarbonate slates. Photo: Langelands Museum

Between each station a stay runs on the sea bed, consisting of orange coloured reinforced clothes line. This is fixed to steel poles intended for electrical cattle fencing, which are inserted 1 metre into the sea bed. The first and last station have a white surface marker buoy $30 \mathrm{~cm}$ in diameter, anchored by a length of railroad track.

In order to permanently install the posters and marker buoys, permissions were obtained from the Danish Coastal Authority (the slabs and stays) and the Danish Maritime Safety Administration (the marker buoys). There was one complaint from a neighbouring farmer during the four week hearing period, but this was overruled.

When the Højklint site had been chosen during the annual cruise for amateur divers, a total of eight diving days were spent on constructing the trail. On the first days the site was dived in a criss-cross pattern in order to localise the best spots for placing the stations. A rough list of the themes for the stations were made, so we had to find a good places to show transgressed trees, worked flint, a nice stretch of eel grass (plentiful!), etc. The team consisted of two divers alternating between diving and tending and a boat driver. The boat was the museums fibre glass dinghy, which was a little bit 
difficult to launch on the beach. The diver reported his observations to the tender, and the spot marked on a hand-held GPS. Although localising and choosing the spots took six days, the actual installation of the trail was done in only two.

\section{Publicity}

Shortly before the trail was to be installed on the seabed, a press announcement was sent via the museum's press list. This resulted in coverage on the regional TV-news, with footage from the actual work during installation. This included underwater footage, since the TV-station cooperates with a marine wild life museum. It was decided to do a more lengthy feature in 2010 when the weather improves and water temperatures are higher. The news clip can viewed via this link:

- http://www.tv2fyn.dk/article/210056:Undervandssti-ved-Langeland

The weekly newspaper covering the island of Langeland carried the press announcement. An interview was given to a national newspaper, which is going to appear in the weekly travel special. The two Danish dive magazines have yet to be approached, but this will happen in due time for Spring 2010. It is the intention to present the trail with its own pages on the museum website, probably with photos from all stations and hopefully all the mentioned species of flora and fauna. If the web server allows for weblogs or guest books (not yet established), some means of receiving feedback from visitors will be set up.

\subsubsection{Norway - The Lossen trail}

by Desiree Ncevdal (Norwegian Maritime Museum) \& Ivar Aarestad (Directorate for Cultural Heritage)

\section{Background}

Over the past few years, Norway's coastline has become a popular destination for divers seeking cultural landmarks under water. A total of 1,425 shipwrecks and other cultural relics are registered in the Norwegian Maritime Museum's area of responsibility in southern Norway alone. The state has ownership rights to ships and other types of cultural relics that are over 100 years old. Older historical wrecks with cargo, especially in the form of cannon, pottery, bottles and bronze objects lie at easily accessible depths. However, such objects are at risk of being removed by divers. Several years ago, the Norwegian Maritime Museum begun a unique program to counteract looting and protect historical landmarks under water by setting up signs to highlight them in the hope that divers would appreciate and respect these attractions. 


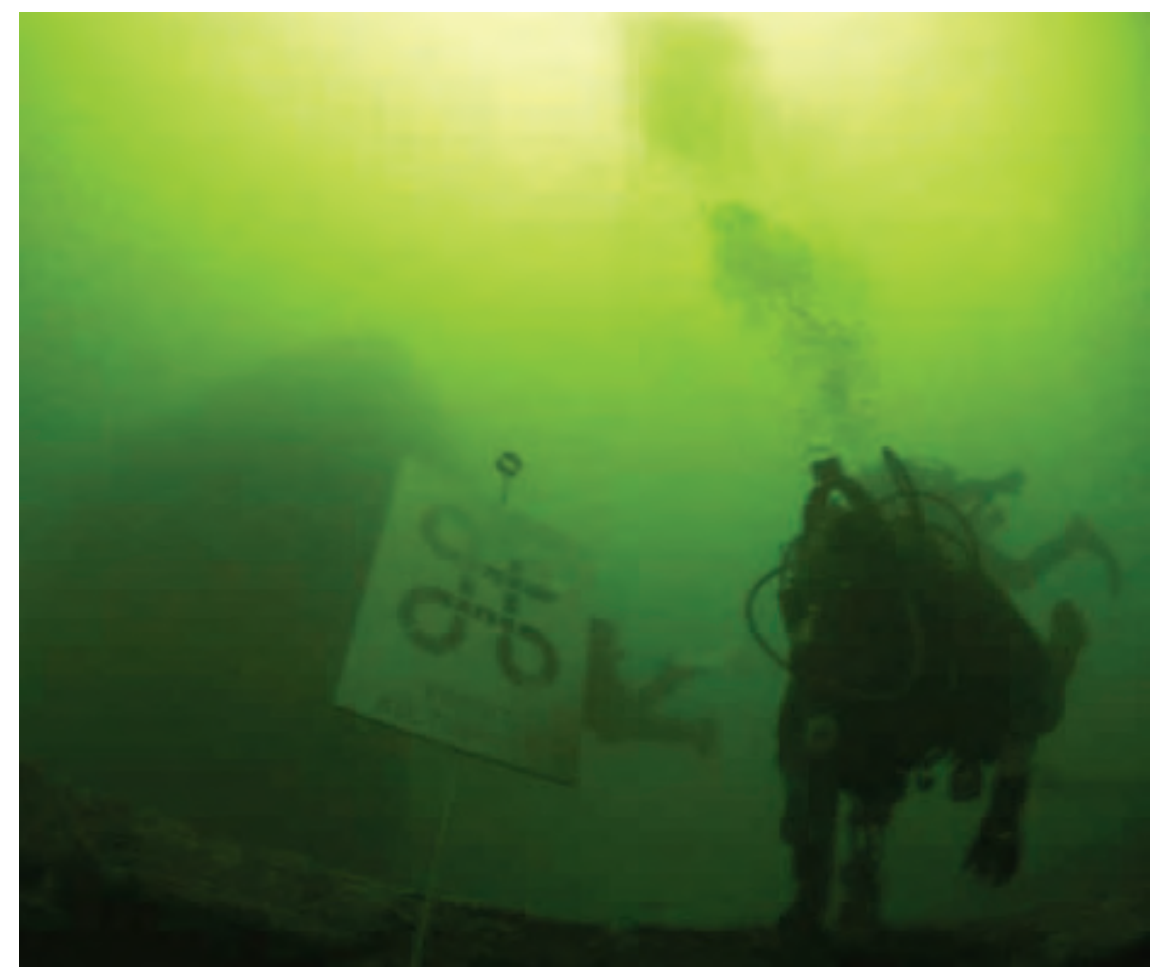

A cultural landmark sign is ready for placement under the waves.

Photo: Pål Nymoen, Norwegian Maritime Museum.

The Norwegian Maritime Museum is in principle restrictive about revealing the position of those wrecks to get signs because in the first phase of the programme, they were placed near attractions that are particularly vulnerable. The country's official cultural heritage signs, made of acid-resistant steel and titanium, have been placed at depths of 10 to 30 metres, near several shipwrecks in southern Norway. Authorities are hoping for cooperation with local divers, who will be asked to help monitor the state of the signs, which are mounted with a gauge at the bottom to measure the amount of sedimentation or erosion.

The Norwegian Directorate for Cultural heritage was included quite late in the Nordic Blue Parks project. The original Norwegian representative in the group was unable to continue the work and the directorate was asked to continue on quite short notice. It was clear to the Directorate early in the process of making trails that we had to rely on a field partner to do the expert analysis, install and maintain the actual test trail. The Norwegian Maritime Museum was contacted and agreed to carry out the archaeological evaluation based on their knowledge of Norwegian underwater cultural heritage. After evaluating the options, a list of possible trails was submitted and we started discussing possible targets for a test trail. The Lossen site was soon singled out and after a field trip to the site on the 23rd of April, 2010, it was finally decided that the location was suitable to be the test trail for the first Norwegian Blue trail. 


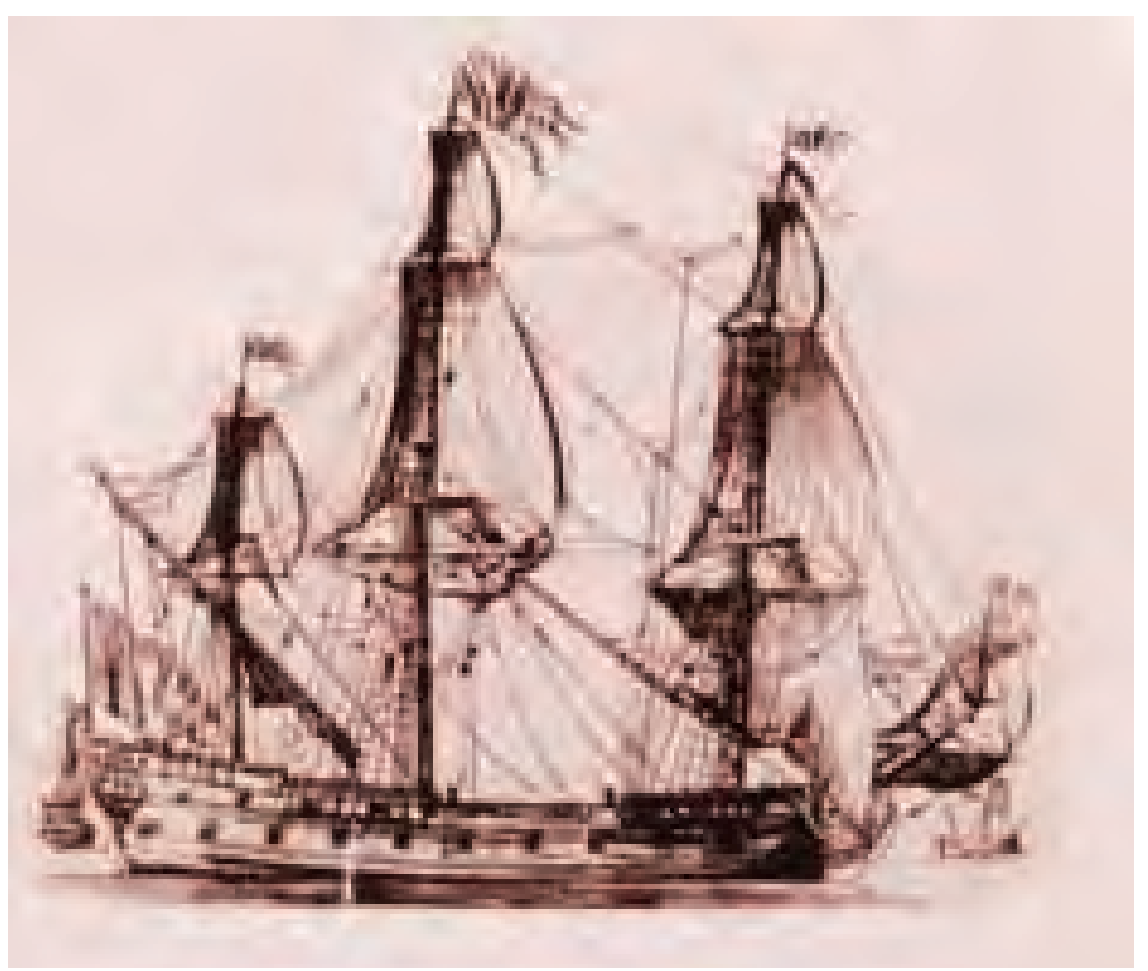

The Lossen may have looked like this.

\section{History}

The frigate Lossen, which is an old Danish word for lynx, was built on the Isegran wharf by the Glomma River in Fredrikstad in 1684. She measured 28.7 metres long and 7.5 metres wide, with a gross tonnage of approximately 676 tons. She often operated with her sister ship Ørnen (the eagle) and they were both practical and economical ships, considered at the time to be the top of their range. Lossen took part in several well known battles such as: Køyebugt (1710), Fladstrand (1712) and the battle at Rügen (1715). When Lossen sank it was under the command of the legendary Norwegian officer, Peter Wessel Tordenskjold, who served in the Danish orlog (naval warship) fleet during "the Great Northern War” of 1700-1721. The ship was smashed against cliffs during a storm on Christmas Eve in 1717 and sank losing 55 souls. Overall, less than half of the crew survived and suffered a traumatic night, searching for help along the desolate cliffs of Hvaler. Locally, there were several stories about the ghosts of the shipwrecked sailors.

When the Lossen sank, she was armed with at least 18 six-pound and 6 three-pound cannons on board, some of which can still be seen today. Ballast stones are also still visible at the wreck site. In addition, approximately 19 metres of the port side hull of the carvel-built ship remain intact. The archaeological remains tell us that it was a solid close-ribbed ship with a quite straight shipside and solid boards, fastened to the ribs with thick treenails. Today, most of the ship lies buried under the sandy seabed, which protects it from the shipworm, Teredo navalis. 


\section{Location}

The wreck of the Lossen (WGS84: N59.0961610, E10.8315144) lies in Stolen Bay on the island of Vesterøy, which is situated in the Hvaler archipelago in the county of Østfold, close to the Swedish-Norwegian border. It was discovered in 1962 and underwent extensive underwater excavation between 1967-69. The excavation had an important impact on Norwegian underwater archaeology and methods developed during this work are still being used today. The excavations revealed an extensive amount of finds and give an excellent picture of how a frigate was equipped in the 17th century. This wreck site is therefore an important reference point for Norwegian archaeology, as well as an important cultural heritage site.

\section{Trail construction}

When considering possible sites for the test trails, we wanted a site that was not too vulnerable. Since the site has been extensively excavated, most artefacts have already been removed. We also wanted to find a site that was not regularly visited by Norwegian sports divers. Diving safety obviously was a major concern and so the relatively shallow waters of the area were suitable.

A boat is necessary to reach the site and diving gear is required to dive the wreck due to its depth. The dive may be quite challenging due to waves and currents. The site is also good for snorkelling but it may be difficult for snorkellers to read the information plates due to their depth. Due to it's position on the border of the "Ytre Hvaler" National Park and the proximity to nesting grounds, visitors are not allowed to visit the the Lossen underwater trail until after the sea birds have finished their nesting period. For the same reason, trail construction did not go ahead until July 2010. Although this wreck site is not the most accessible, we have been in contact with the proper authorities to get a permanent mooring solution on the site. While it has relatively easy access from sea, the site is vulnerable to prevailing south and south west winds and occasional rough seas. The site is accessible by land, but not by car.

Although the trail will focus on the wreck, it will also include information plates on the animal and plant life at the site and in the area. These will consist of digitally printed signs laminated with clear plastic on a plate of anodized aluminium, attached to concrete garden paving slabs. At the site, one of the plates will include an explanation of the cultural heritage sign, giving a thorough clarification of how the cultural heritage law of Norway is enforced. 


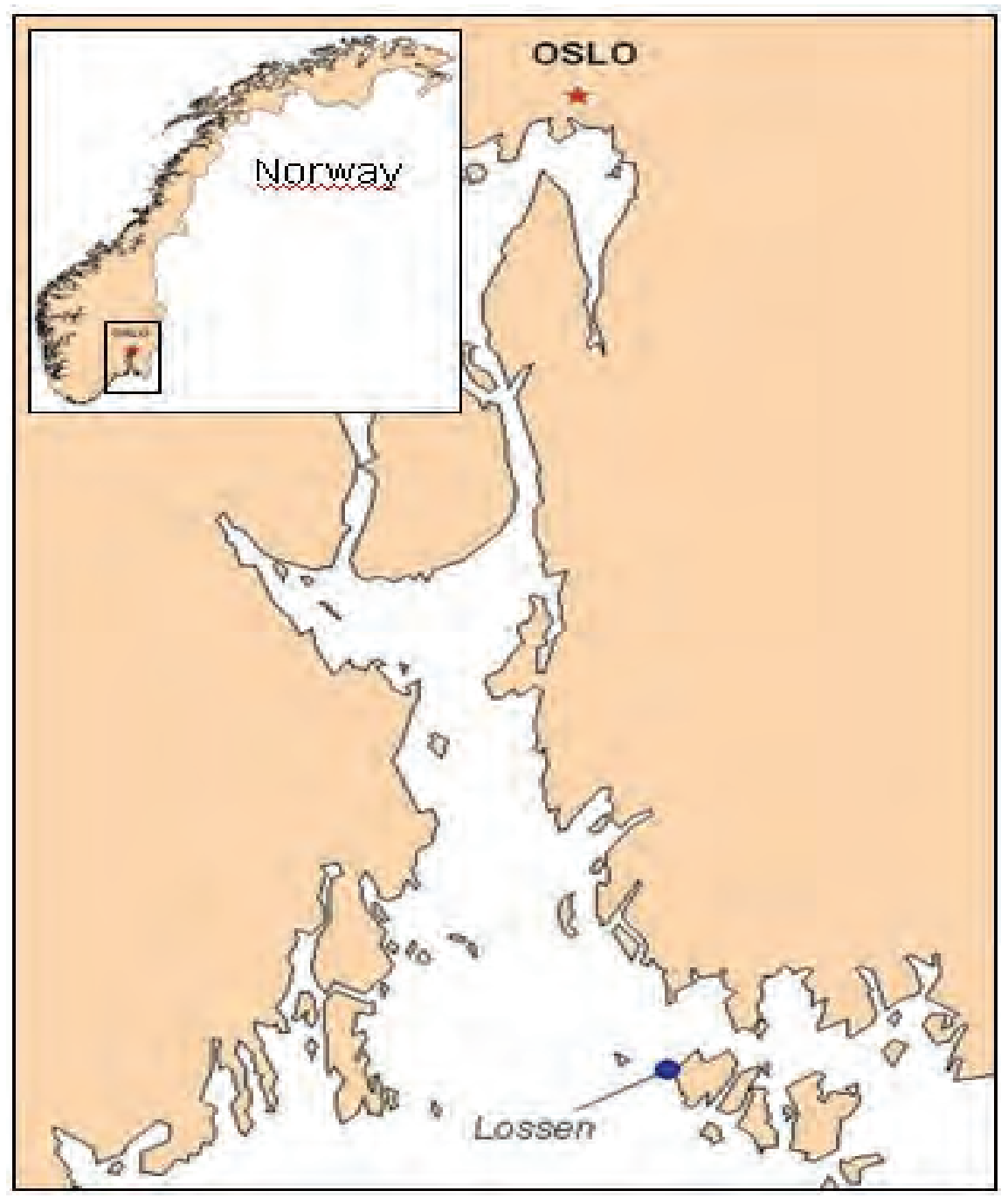

Location of the wreck of the Lossen at Stolen Bay, Vesterøy Island. Photo: Norwegian Maritime Museum 


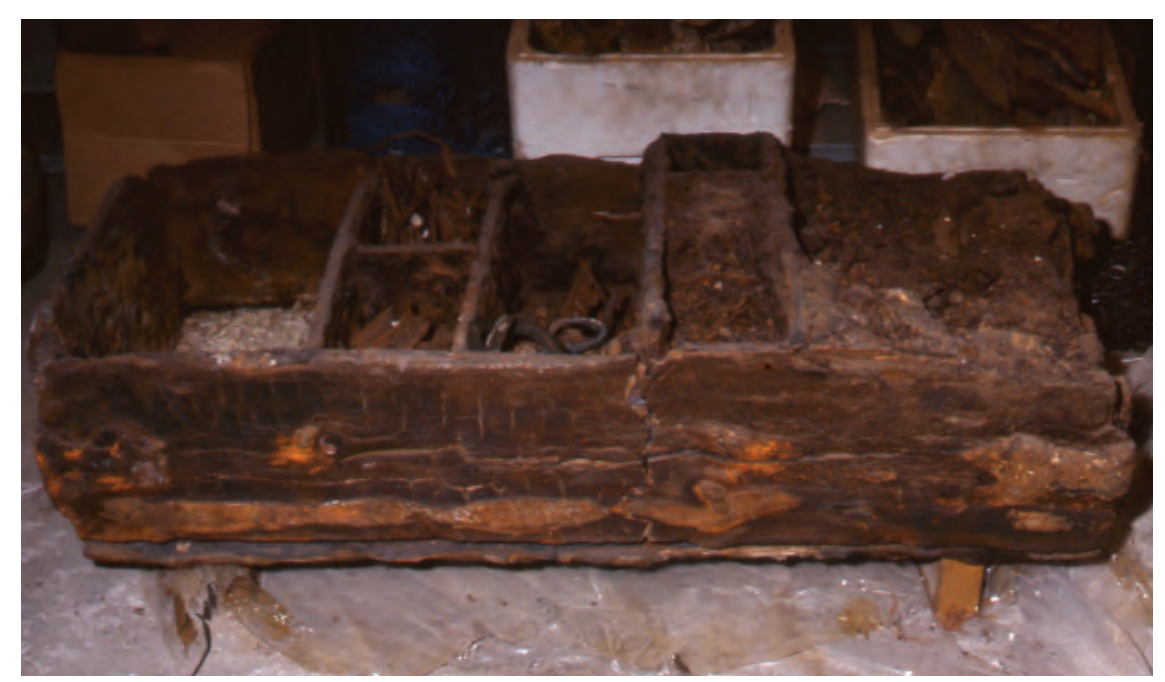

A carpenter's chest with nails and rivets.

Photo: Norwegian Maritime Museum

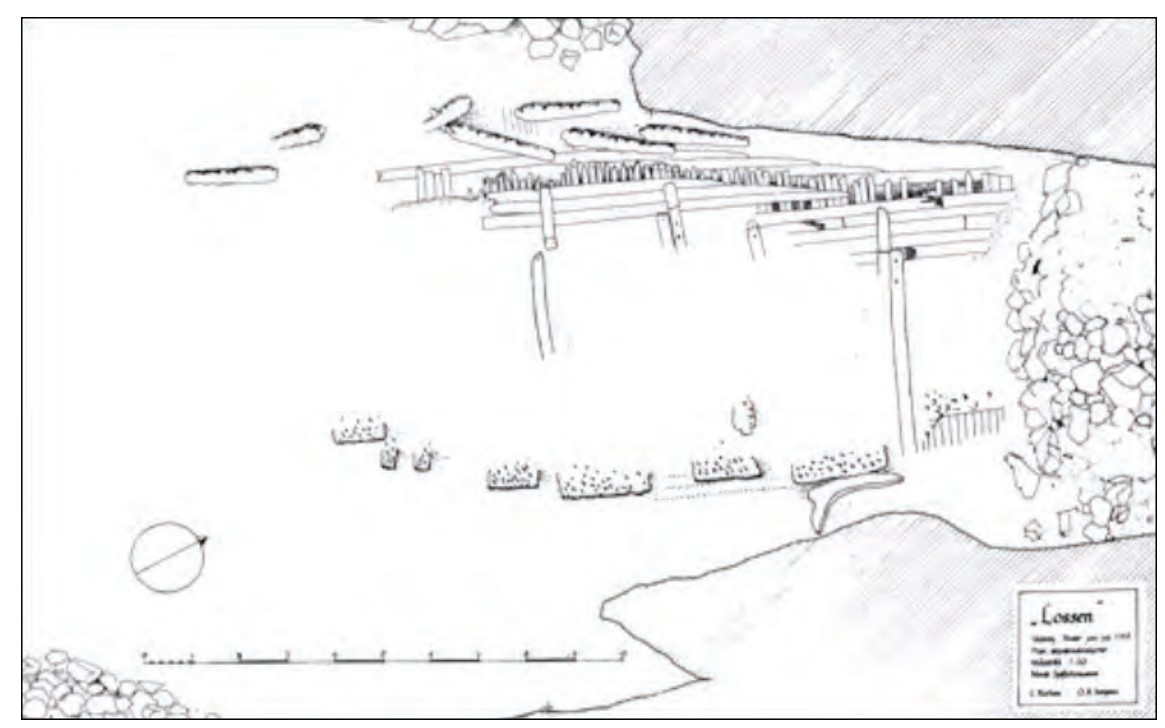

A plastic slate will be available for purchase to divers showing the layout of the wreck and the position of underwater features such as cannons and ballast stones.

Photo: Norwegian Maritime Museum

Additional plates include information on four to five species of local flora and fauna identified by our technical conservator who also is a biologist, e.g. brown (Phaeophyceae; Fucales: Laminariales, e.g. Laminaria saccharina), red (Rhodophyceae, e,g, Rhodomela confervoides) and green algae (Cladophora $s p$.). The plate on fauna will include some general knowledge about the national park and further information about certain species such as blue mussels, Mytilus edulis, butterfish, Pholis gunnellus, and hermit crabs, Pagurus bernhardus, as well as other species observed at the site. It will also be possible for visitors/divers to purchase a plastic slate which gives information on the wreck site and which can be taken along on the dive. 


\subsection{Work Packages}

\subsubsection{WP1-Status/Quality Assessment of nature and culture sites}

Work package 1 involves the preparation of standards for carrying out assessments by identifying a top set of sites most suitable for establishing a Blue Park with Blue Trails (dive trails). Thus, we acknowledge the resilience, accessibility and the "good story" of a location to facilitate the marketing of the site.

3.6.1.1. Nordic Map of potential Blue Parks/Trails from each of the Nordic Blue Park member countries

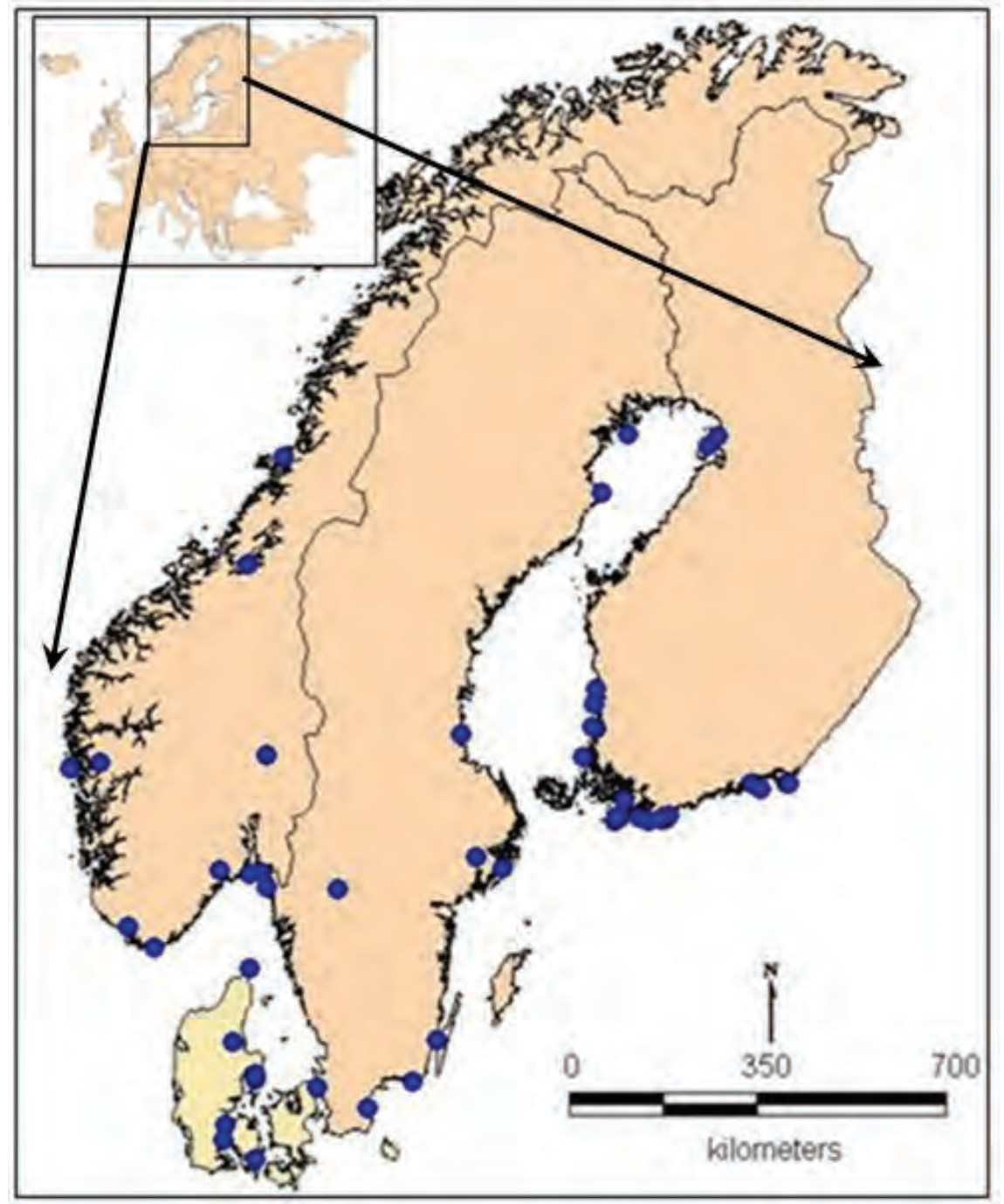

Nordic map of potential sites for Blue Parks and Trails from each of the member countries of the Nordic Blue Parks project, Norway, Sweden, Finland and Denmark. 


\subsubsection{Top locations for potential underwater trails: Finland}

In Finland, the top ten sites for potential underwater trails were each compiled for both cultural and nature heritage.

\section{Cultural trails}

The locations for potential underwater culture/shipwreck trails were compiled by Sallamaria Tikkanen of the National Board of Antiquities, Finland, based on expert opinion.

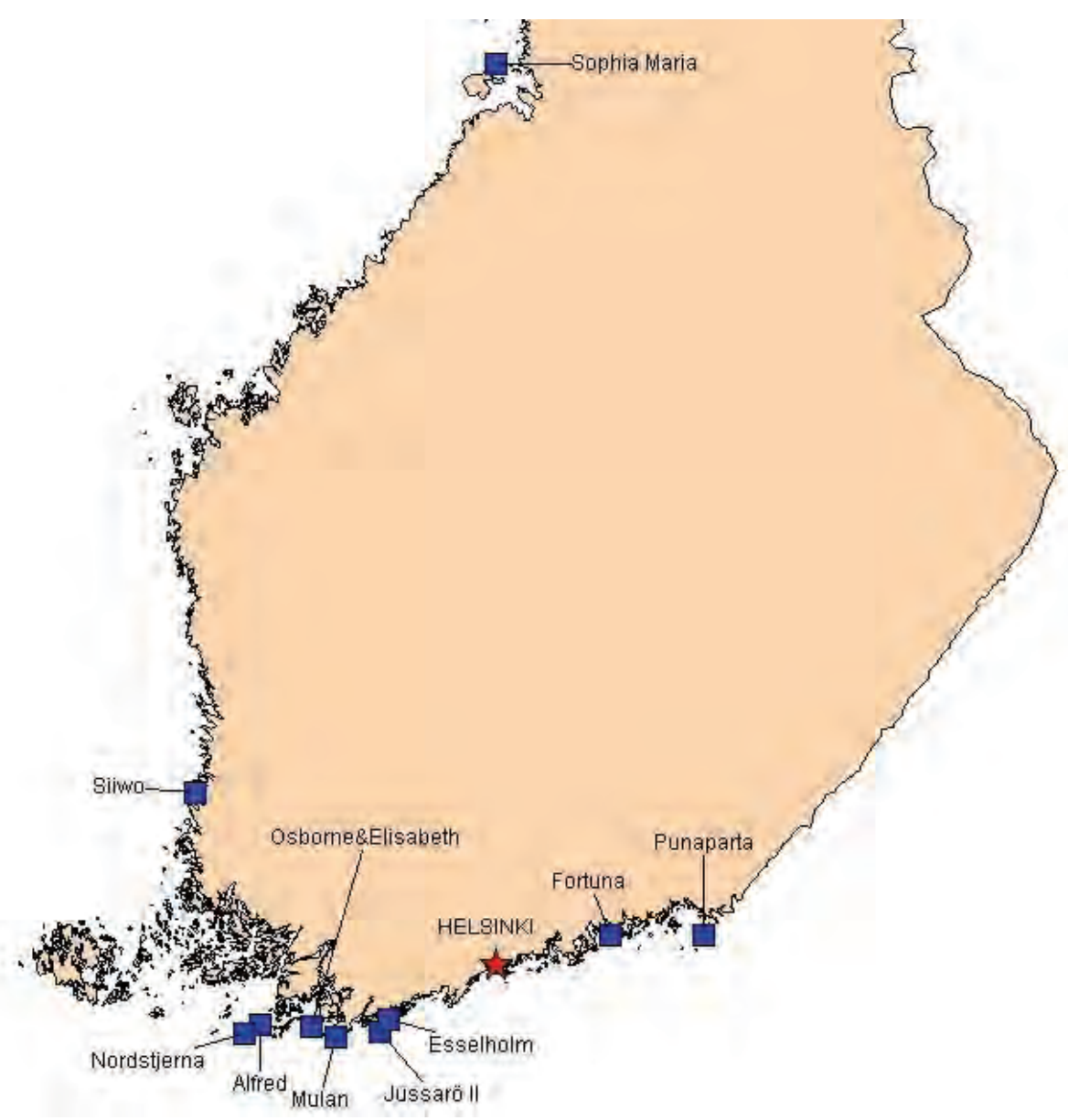

Top ten locations for underwater cultural trails as potential Finnish Blue Parks.

The wreck of the Osborne \& Elizabeth (WGS84: N59.861232, E22.768964)

Thought to be of English origins, this brig which now lies at a depth of 17 metres on a clay/mud seabed sank in 1873. It is quite large, measuring 28 metres in length and 7 metres in width and largely intact with some deck boarding missing or damaged. A check up survey was carried out in 1996. The wreck lies 300 metres distant from a boating lane in the Tammisaaren National Park area and is a popular site for divers due to its high visual appeal. A boat is required to dive the site which is at least 200 metres from the nearest shore. Although the visibility is usually good, the muddy bottom is easily 
disturbed and it is considered dangerous to enter the wreck. The wreck has suffered from diving. Sources: Marko Röhr Productions (1996); Vaheri et al. (1996).

The Wreck of the Alfred (WGS84: N59.873167, E22.167749)

This English frigate sank in 1854 close to the island of Vänö, which is now situated in the Archipelago National Park. Measuring 25 metres in length, the Alfred lies on a sandy bottom at a depth of 20 metres. A check up survey was made in 1996 and some artefacts were recovered. It is in fairly good condition with some damage and missing decking. A boat is required to dive this wreck which is a popular spot for divers. The wreck is $\mathbf{4 5 0}$ metres from the nearest boating lane and the visibility is usually good (4-8 $\mathrm{m})$. The Alfred has suffered from looting and diving. Sources: Metsävuori (1984, 2000); Moisala (1976); Mannerkoski (2007).

The Wreck of the Sophia Maria (WGS84: N65.141270, E24.954352)

This Dutch schooner or koff sank in 1859 and now lies at 18 metres. It has been extensively excavated between 1977 and 1985. The Sophia Maria is a large wreck (ca. $28 \times 6 \mathrm{~m}$ ) and is in quite good condition although some decomposition has been noticed during excavations. The visibility is quite poor and the nearest sea lane is only 200 metres away. A boat is necessary to dive this wreck. Sources: Metsävuori (1984); Grönhagen \& Konttinen (1988); Kehusmaa (1998).

Jussarö II/Hopeapriki (Graf Nikita 1784 or Constant Trader 1785) (WGS84: N 59.832583, E23.567130)

As the multiple names suggest, the provenance of this wreck remains unclear. This large ( 28 x $7 \mathrm{~m}$ ) two/three masted sailing vessel may be of Russian, English, German or Dutch origin and is thought to date from the 18th century. It lies on a muddy bottom at a depth of 17 metres in the Tammisaaren National Park. It is still in good condition with only some damages and has been excavated between 1978 and 1981. While it is only 20 metres from the nearest shore, it's offshore position requires a boat to dive there. Visibility is poor (03 metres). Sources: Ahlström (1981, 1997); Edgren (1979); Grönhagen (1970, 1980); Vaheri et al. (1996) Grönhagen \& Konttinen (1988); Alopaeus (1970, 1989).

The Esselholmen Wreck (WGS84: N 59.898398, E23.689189)

This 16th century merchant vessel believed to be from Holland measures 18 $\mathrm{x} 6$ metres, whose depth ranges from 6 to 16 metres. This wreck has been excavated and several check ups made. Some artefacts have been recovered. The wreck has sustained a lot of damage with a lot of decking missing. The closest boating lane is only $40 \mathrm{~m}$ away with a sea lane 140 metres distant. The visibility is variable with a maximum of five metres. Although only 40 
metres from the nearest shore, a boat is required to dive this offshore site. Sources: Edgren (1978a, 1978b); Halme (1978); Alopaeus (1989).

The Wreck of the Siiwo (WGS84: N61.139570, E21.400061)

This German-built 26 metre schooner went down in 1898 and now lies on on a soft muddy bottom at 10 metres depth. Its condition is poor, having sustained a lot of damage with a lot of decking missing. Some of the ribs are visible and the stern is broken up. The visibility is variable, ranging from $0.5-5$ metres. There is a boating lane 80 metres away. A boat is required to dive this site. (Sources: http://www.hylyt.net/hylky.jsp?id=siiwo)

\section{The Wreck of the Nordstiernan (WGS84: N 59.824212, E21.974566)}

The barque Nordstiernan was built in Rostock, then part of the Swedish empire and sank in 1809 in what is now the southern Archipelago National Park. It was carrying linen, hemp, porcelain and glassware. It lies on a muddy bottom at a depth of 18-23 metres and measures at least 30 metres in length. It has been investigated between 1977 and 2000, with a check-up in 1996. It has sustained considerable damage due to salvage efforts in the 1920's which used explosives. A boat is required to visit this site. There is some concern that opening this site as a Blue Park might impact on the more sensitive and protected wreck site of the Sankt Mikael, which lies only one kilometre distant. Sources: Metsävuori (1991, 1999); Vaheri et al. (1996); Johnsson (1988).

The Punapartojen Wreck (WGS84: N60.360780, E27.396542)

This three-masted sailing vessel of unkown provenance went down at the beginnig of the 1800's and lies upright on a sandy seabed at depth of 19-30 metres. It is a large wreck, measuring $40 \times 8$ metres. It has undergone multiple check-ups between 1979 and 1997 and has suffered from looting. It is in good condition, with a portion of the rib planking collapsed, as well as missing decking from mid-ships. The stern and bow are still intact. Calm weather and a boat is required to dive this wreck. Visibility varies from 1 to 5 metres and a torch is recommended. Sources: Vaheri et al. (1996); Fast \& Mertanen (1996).

The Wreck of the Fortuna (WGS84: N60.359303, E26.308932)

Built from oak in 1811, this Finnish three-masted frigate sank in 1822 and now lies on a muddy bottom at depths of $10-15$ metres. It measures 35 metres in length and 10 metres in width and is in good condition with some planking missing. The stern has collapsed. Two check-up surveys were carried out in 1996 and 1999. It is situated less than 200 metres from a boating lane. Visibility is variable $(0-5 \mathrm{~m})$, the muddy sediments are easily disturbed and is generally poor in summer. There is a risk of disturbance/damage by divers. Requires a boat to visit the wreck. Sources: Metsävuori (1984); Henriksson (2003). 
The Wreck of the Mulan (WGS84: N59.807334, E23.065136)

This wreck, a clinker-built one/three master thought to be from Sweden, sank at the beginning of the 17th century. It now lies at depths of 13-15 metres on a sand and gravel bottom. It measures $12 \times 4.5$ metres. It has been excavated between 1988 and 1995 and loose artefacts have been recovered. Archaeological courses have also been organised on this wreck. The site is safe and suitable for beginners although it may not be so interesting as it is in very poor condition, comprising mainly loose planks. A boat is required to visit this offshore site. Sources: Ikonen \& Nurmio (1995); Marko Röhr Productions (1996); Konttinen (1992); Tikkanen (1992); Sammallahti (1994); Nurmio (1995).

\section{Nature trails}

The locations for potential underwater nature trails were compiled by Kevin O’Brien of Metsähallitus/Forstsstyrelsen based on the expert opinions of the in house regional marine biologists.

Högland, NE Archipelago Sea (WGS84: N60.105433, E22.312778)

According to Mäki (2009), the island of Högland ranks is considered to experience low tourist pressure. This forested island lies within a Natura 2000 area and is maintained by Metsähallitus. It has a natural harbour and a small pier and facilities include information boards, toilets, a campfire and area for camping. There is a nature trail on the island which includes a lookout tower at the highest point. There are two wrecks (mostly loose planks) at the northern tip and western side of ther island. The underwater nature is diverse with rocky shore, soft bottom fauna and vascular plant communities. There is a sea lane passing $130 \mathrm{~m}$ to the east of the island. Visibility is variable. A boat is necessary to reach Högland but it is possible to rent a taxi boat also. 


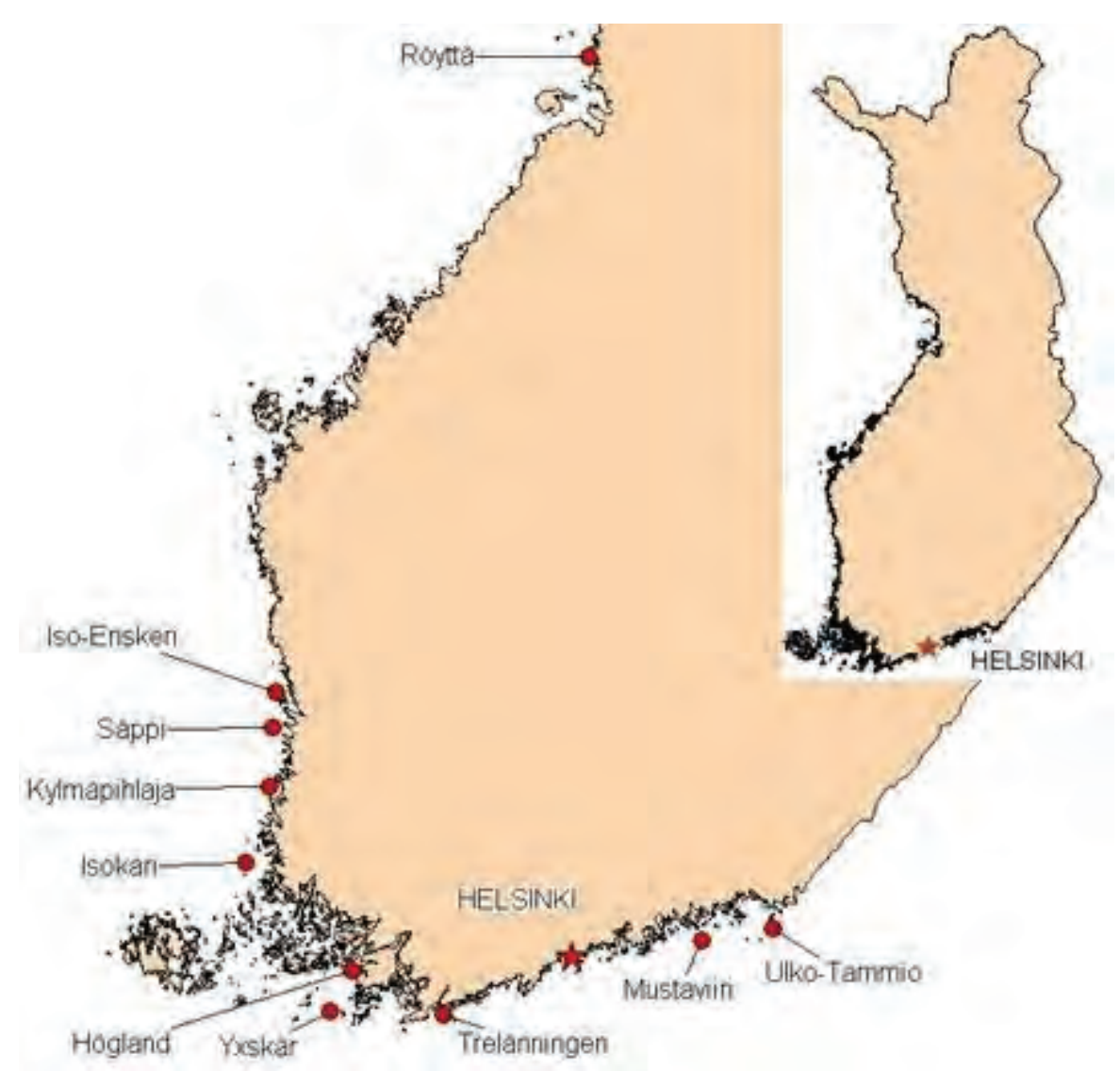

Top ten locations for underwater nature trails as potential Finnish Blue Parks.

Trelänningen, Ekenäs National Park, Ekenäs. (WGS84: N59.84050, E23.38299)

This outer archipelago island is approximately 200 metres long and is situated in a Natura 2000 area and maintained by Metsähallitus. Although it posesses a sheltered natural harbour, there are no other facilities on the island. This is already a popular site with trainee divers in the sheltered lagoon, as well as offering a wreck on the southeastern tip of the island for more advanced divers. The wreck comprises a wooden hull broken into two pieces. The sheltered bay is dominated by vascular plants, such as the seagrass, Zostera marina, and the sensitivity of such plants to anchor scarring has led to the prohibition of anchoring at the south east corner of the island (Oulasvirta \& Leinikki, 2003). The nearest boating lane is approximately one kilometre away making this a very peaceful spot. A boat is required to visit the island.

Ulko-Tammio, National Park of the Eastern Gulf of Finland. (WGS84: N60.350274, E27.464792)

This national park, which includes over 100 islands and islets was established in 1982 to preserve the indigenous wildlife and habitats of the marine archipelago. The park covers over a $60 \mathrm{~km}$ wide area which is administered by 
Metsähallitus. The land and water around this forested island are situated in a Natura 2000 zone. Ulko-Tammio was an important military outpost during World War 2 and the fortifications from this time are being preserved as national monuments. There is a nature trail on the island, information boards, a campfire site and camping, a waste disposal site and a well for freshwater. Organised tours are arranged for visitors during the summer months when there is a daily ferry. There is a shipwreck located off the north eastern shoreline, while the Punapartojen wreck (see below) lies a mere $3.8 \mathrm{~km}$ to the north west.

\section{Mustaviiri/Svartviran (WGS84: N60.274905, E26.598650)}

Situated in the westernmost portion of the national park, this forested island is administered by Metsähallitus and is in a Natura 2000 area. The island has shallow natural harbours on the eastern and a site for camping with toilets and a waste disposal point. There is a cultural-nature trail on the northern part of the island. The shores are mainly rocky with associated underwater communities. This is in stark contrast to the long sandy beaches on nearby Pitkäviiri. The nearest boat lane is ca. $3.5 \mathrm{~km}$ distant, making this island a very peaceful spot to visit with your own boat. There is no ferry service.

\section{Röyttä, Oulu (WGS84: N65.276230, E25.211940)}

About $40 \mathrm{~km}$ north of Oulu city and $4 \mathrm{~km}$ west of Praavannokan harbour, Röyttä is a low-lying island ( $5 \mathrm{~m}$ above sea level) which covers an area of 60 hectares. Historically important since medieval times a as a fishing spot, it later became a base for loading wood onto ships. Today, it is a popular island for visitors and is maintained by Metsähallitus. Two thirds of the island has bee designated a Natura 2000 zone. The sheltered harbour lies at the southern end of the island and hosting two piers which offer electricity for boaters, information and toilets. In addition, there is a fireplace, a nature trail and accommodation and sauna for rent. Taxi boats can be hired from the mainland. The underwater landscape is comprised of shallow sandy and gravelly bottoms in which vascular plant species grow well, often in subaquatic "meadows”. Rare aquatic mosses can occasionally be found also.

Kylmä-Pihlaja, Rauma (WGS84: N61.144407, E21.299670)

Lying in the Rauma archipelago, this island sports a 36 metre tall lighthouse, which houses a small family hotel. There is also a pilot station with wave beakers and a sheltered harbour with space for about 20 boats. There is an interesting and diverse flora on Kylmä-Pihlaja, while a survey in 2001 counted 28 different species of nesting birds. There are regular boat services running to the island during the summer months (June-September). Further services include a café, restaurants, chapel, sauna, toilets, an information centre and chapel. Due to its exposed location, it may be difficult or even impossible to get to or from the island in rough weather. 
Iso-Enskeri, Pori (WGS84: N61.680960, E21.373590)

The island of Iso-Enskeri lies in the Gummandooran archipelago which has largely maintained its natural habitat. While the island lies within a Natura 2000 area covering most of the Gummandooran archipelago, the northern part of the island is a private nature sanctuary. The flora and fauna found here are highly representative of the area. Iso-Enskeri is forested and supports a rich gull and waterfowl population. Some fishing cabins have been built in the archipelago but it is otherwise undeveloped and can be reached either with your own boat or with the cruise ship Charlotta, which can be boarded in Pori. There is a pier for visitors at the southern tip of the island, close to which are a campfire, a waste disposal point and a toilet. The visitor jetty is more suited to small boats.There is also a swimming beach and nature trail. Berry picking is a popular seasonal activity for visitors. There is a shipwreck (Munakari wreck) situated $1.7 \mathrm{~km}$ to the notheast of the island. Due to its exposed location, it may be difficult or even impossible to get to or from the island in rough weather.

\section{Säppi, Pori (WGS84: N61.480795, E21.339484)}

Situated about $5.5 \mathrm{~km}$ from the mainland, Säppi is a forested island which covers ca. 150 hectares and is well known for its white 20 metre tall lighthouse, built in 1873. The island lies within a Natura 2000 zone and has nature protection areas covering most of the island. Of these, the southern portions are state-owned broad-leafed woods. By contrast, the privately-owned nature reserves in the northern part of the island have been mainly cleared of trees and now comprise dense birch and mixed species woods. It is a popular site for bird-watchers, acting as a bird sanctuary since 1959. Almost 290 different bird species were counted in a 2001 survey. It is possible to get basic accommodation at the bird sanctuary station, which also has a sauna, well, and toilets. Getting to the island is relatively easy with local fishermen and there are also taxi boats available, which organise guided tours. There is a guest harbour on the western shore and a natural harbour on the north eastern shore. There are two shipwrecks lying in shallow water, i.e. $<5$ metres, to the west of the island. Due to its exposed location, it may be difficult or even impossible to get to or from the island in rough weather.

Yxskär, SE Archipelago Sea (WGS84: N59.875800, E22.052427)

Based on a visitor survey to the Archipelago National park in 2008, the small island of Yxskär ranked 14th in terms of visitor numbers (Mäki \& Sarlin, 2009). The island is in a Natura 200 area and is maintained by Metsähallitus. There are several natural harbours to anchor around the island which has a nature trail, a camping place, a camp fire, toilets and information boards. The island boasts both a flad and a gloe-lake. The former is a shallow bay connected to the sea by one or more inflows. When the bay is fully separated from the sea it becomes a gloe-lake. Both features are important for their biodiversity, particularly for aquatic plants and as spawning 
grounds for fish. The rocky shores around the island support bladderwrack, (Fucus vesiculosus) and blue mussel communities. The visibility here is usually good in the summer.

\section{Isokari, Uusikaupunki (WGS84:N60.72241, E21.01782)}

Situated 12 nautical miles south west of the city of Uusikaupunki, Isokari island is well-known for its red-and-white striped lighthouse, which reaches an impressive 49 metres above sea-level. There is also a working pilot station on the island, a small village, old army buildings and guns and fantastic nature with almost 380 plant species. The island also boasts a gloe-lake, with associated rich flora. All of the island and surrounding waters have been designated a Natura 2000 area, except for the pilot station environs and area around the lighthouse. In summer, organised guided tours take place around the island from June onwards. The is an archipelago centre which has a handcrafts and photography display. There is a kiosk on the shore near a guest pier in the sheltered harbour on the eastern side of the island. There is no regular ferry service to the island but boat taxis and water buses are available. Due to its exposed location, it may be difficult or even impossible to get to or from the island in rough weather.

\subsubsection{Top 10 locations for potential underwater trails: Sweden}

These locations were compiled by Pernilla Flyg of the Swedish National Maritime Museum and chosen for their suitability as potential Blue Parks sites, based on expert opinion.

\section{Axmar (WGS84: N61.054931, E17.165483)}

The 17th century iron works at Axmar on the east coast north of Gävle is part of the industrial heritage of Sweden. The waters outside the Axmar iron works are crowded with wrecks and constructions related to the local iron works industry and trade. Axmar is a nature preserve and a marine protection area. The Axmar iron works area will also become a culture preserve during 2010. Sweden's First Blue Parks dive trail will be opened here in 2010. Three sites have been selected to be included in the first trail, but there are several potential sites to be included later on. Some of the shipwrecks and the flora and fauna typical for the Bothnian Sea, lie in very shallow water and are thus extremely accessible. Local and regional authorities are actively involved, as well as local history associations and business entrepreneurs. The area is a nature reserve, and will also become a culture reserve in 2011. 

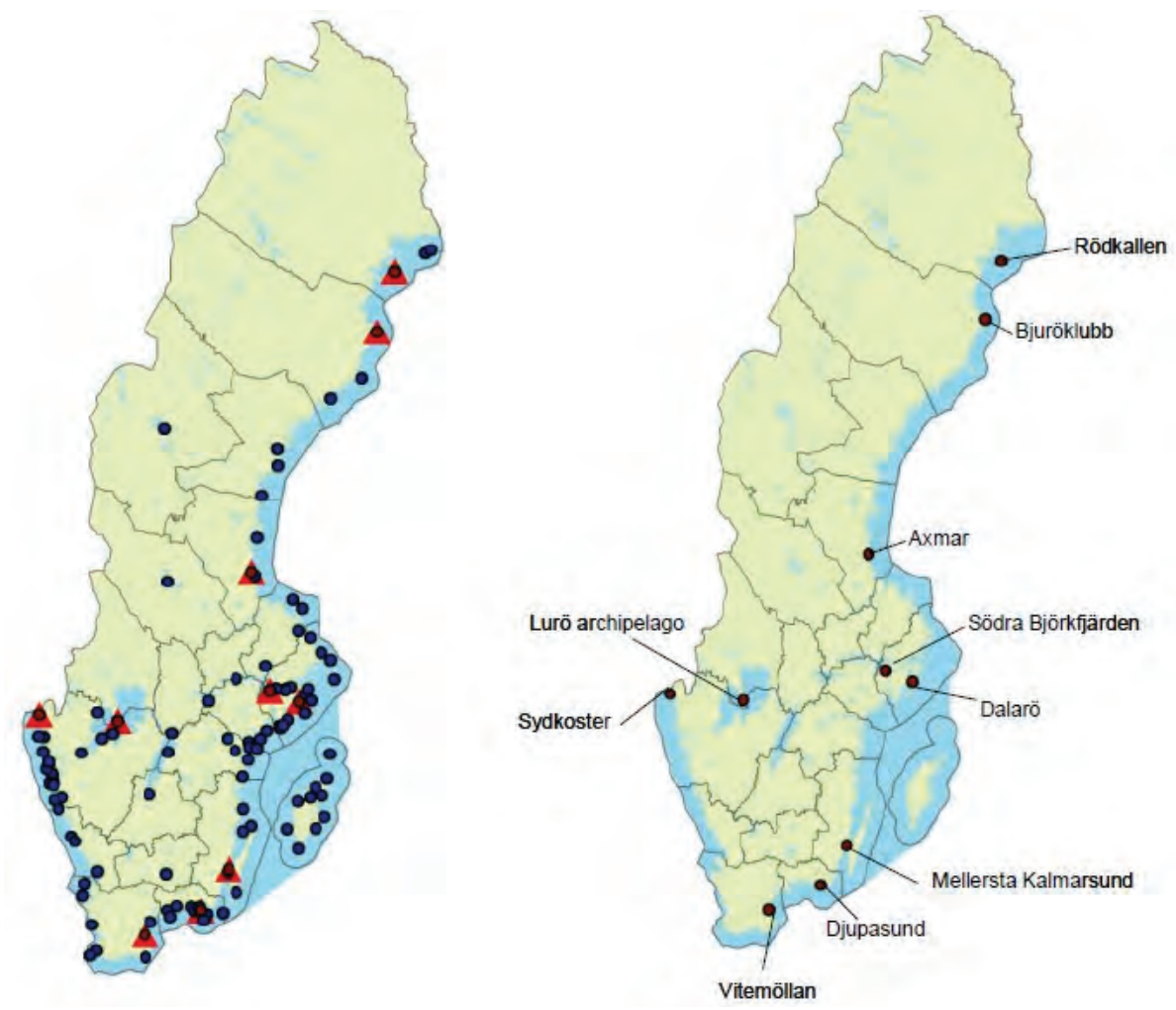

(Left)100 sites for potential Swedish Blue Parks (blue dots) plus selected top ten locations (red dots/triangles). (Right) Names and locations of the top ten sites.

Mellersta Kalmarsund, Kalmar strait (WGS84: N56.705442, E16.378298)

During the 16th and 17th centuries, several naval battles were fought between Swedish, Danish and Dutch fleets in the Baltic Proper. The Kalmar strait was used for retreat and regrouping. At least five shipwrecks are located in the area, three of them the Swedish warships "Elefanten" (The Elephant), "Enighet” (Unity) and "Nyckeln” (The Key). These shipwrecks are promoted by the Kalmar regional museum, which offers a downloadable folder for visiting divers and other interested parties.

Djupasund (WGS84: N56.105239, E15.635954)

Djupasund is located outside the Swedish 17th century naval town and World Heritage Site of Karlskrona and is one of several straits in the area with shipwrecks. The site is a popular destination for divers, and it is called "vrakkyrkogården" (the wreck cemetery). A total of about 20 discarded shipwrecks of various types (such as frigates, brigs and East Indiamen) were integrated for defence reasons within the rampart constructed in the Djupasund strait in the 18th and 19th centuries. 
Sydkoster (WGS84: N58.879798, E11.030660)

Sydkoster is one of the Koster Islands, famous for being Sweden's westernmost populated islands. They are surrounded by the Koster Archipelago, Sweden's first marine national park with a unique species richness and a cold-water coral reef. There are four registered shipwrecks in the area, among them a shallow shipwreck with timbers dendro-dated to the 14th century.

The Lurö archipelago (WGS84: N58.850881, E13.250007)

The Vänern lake is the third biggest lake in Europe, and the archipelago in the central part of the lake, is the largest archipelago in Europe. It is also a nature reserve. Some of the islands are bird habitats, and visits are prohibited during April-August. Around 700 shipwrecks have been found in Vänern so far, many in the Lurö archipelago. The area has been inhabited in the Viking age, and a spear-like object and something that has been interpreted as a sword have been found near one of the shipwrecks.

Bjuröklubb (WGS84: N64.470551, E21.573736)

Bjuröklubb is a peninsula in the Västerbotten archipelago. Bjuröklubb is a nature reserve and a popular dive site. Around ten shipwrecks are registered in the area, among them an old (probably 16th century) wreck known as Tegelvraket (The Brick Wreck) and the steamer Craigland.

Rödkallen (WGS84: N65.313502, E22.377423)

Rödkallen is part of the Rödkallen-Sörespen nature reserve. It is also a popular divesite. A shipwreck regularly visited by divers is "Meri", a wellpreserved 20th century steamer. Rödkallen is also famous for its 19th century lighthouse designed by Von Heidenstam, as well number of mysterious stone mazes. The nearby town of Luleå will become the starting point (September 2010) for a "road show"-project run by the National Maritime Museums in order to highlight maritime cultural heritage around the Swedish coasts.

\section{Dalarö (WGS84: N59.132630, E18.426355)}

Dalarö, situated on the sailing route to Stockholm, used to be an important area for trade and for the navy. The waters are crowded with shipwrecks, some of them extremely well preserved, such as the 17th century Dalarövraket (the Dalarö Wreck), but there are also more modern shipwrecks such as the 20th century cargo-ship "Ingrid Horn”. Although diving is prohibited on some of the shipwrecks, the National Maritime Museums are working on methods to provide non-harmful access through the techniques of "dry diving" and guided historical diving. Dalarö is not far from Nåttarö where a snorkeling nature trail was opened in 2009. 
Vitemöllan - Haväng (WGS84: N55.729656. E14.188265)

The Vitemöllan-Haväng nature reserve has some of the most beautiful scenery in the Skåne region. Situated on a ridge near the water lies the famous Haväng stone age grave. About 1.5 kilometres from the coast, an exceptionally well-preserved 9000 year old submerged prehistoric forest has been discovered. There are also signs of submerged Paleolithic human activity and settlement.

Södra Björkfjärden (WGS84: N59.298473, E17.610355)

A great number of mostly unidentified shipwrecks can be found in the waters close to Björkö, most of them discovered by side-scan sonar mapping. It would be very interesting to investigate if any of these shipwrecks could be linked to the 8th century trade town of Birka.

\subsubsection{Top 10 locations for potential underwater trails: Denmark}

These locations were compiled by Otto Uldum of the Langelands Museum and ranked for their sutability as potential Blue Parks sites based on expert opinion.

Stinesminde, Mariager Fjord (WGS84: 56.665407, E9.964280)

Lying at a depth of 14 metres is a well preserved wreck of a small early 17th century merchantman. The wreck is almost entirely preserved from the keel to the gunwale and even includes the skipper's cabin with berth. The wreck has been partly investigated despite being filled with sediment. In addition, because the primary threat stems almost entirely from looting, the wreck was covered with fishing net to protect it. Therefore, the wreck would need to be partly excavated and documented prior to any inclusion in the Blue Parks project. If prepared thoroughly this wreck could be an exceptional historical diving experience. Diving is quite easy and the site is easily accessible from the beach.

Margrethes Bro/Æ Lei, Haderslev Fjord (WGS84: N55.285075, E9.658892)

Iron Age and Medieval pole blockages (sea defences) with well-preserved poles and other structures are found at this site. The waters in this area are free from shipworms and the relatively hard sea bed make for good visibility. In addition, the pole blockages from both periods are situated quite near each other. Overall, the conditions for experiencing a little known category of archaeological site are exceptionally good. The dive is quite easy. There is little current, the defences lie at a depth of three metres and can be accessed from the shore. The primary threat to the site involves moderate erosion, while divers pose only a minor threat. 


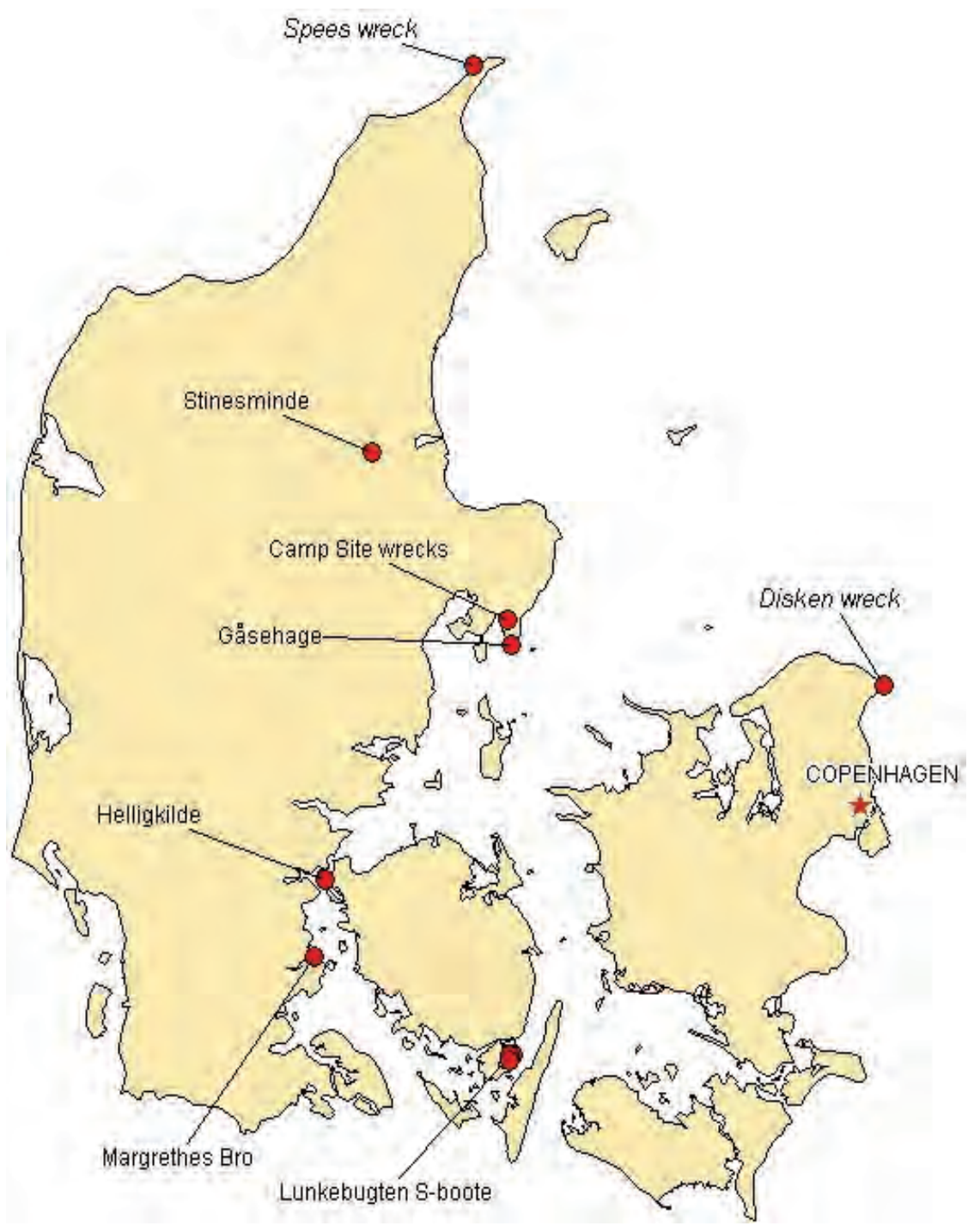

Top ten locations for potential Danish Blue Parks

Torpedo boats, Lunkebugten Bay (WGS84: Wreck 1: N55.013167,

E10.694017; Wreck 2: N55.016867, E10.700933; Wreck 3: N55.016083, E10.682650; Wreck 4: N55.001967, E10.685367)

In May 1945, four World War II German navy motor boats or "schnellboote" were scuttled by their crews and now lie on the silty seabed at ten metres depth in an area of low currents. Three of these wrecks have long been known and have suffered from looting for loose objects, including the large numbers of spare propellers. More recently, a fourth wreck was discovered, parts of which were raised by a salvage company and sold to a British collector. As a group, these four wrecks comprise a very interesting opportunity to dive on men-of-war from WWII, at modest depths. Further looting by divers forms the main threat. 
Helligkilde, Fænø Sound (WGS84: N55.493299, E9.714009)

This site comproses a submerged Mesolithic settlement area (waste) with lots of worked flint, ceramics and wooden material at depths as little as two metres. A limited investigation was carried out in 2003, which showed that the site has great potential because it is protected by a thick layer of peat and gyttja (a fine-grained, nutrient-rich organic mud deposited in lakes and ponds). The site is easily accessible, being only a short boat ride from the nearby marina. With a bit more effort to carry diving gear, the site can also be dived from the shore. Although there are little current in the area, the site is under some threat from erosion.

The Gåsehage Wreck- Moesgaard (WGS84: N56.137646, E10.692405)

Lying at a depth of three metres, this wreck dates from the early 18th century and has been investigated on several occasions during the 1990's. A range of associated finds have been recovered, including clothing, personal belongings and a cargo of grain in barrels. Although the degree of exposure varies, the hull structure is still coherent. The site is subjected to a strong current twice daily. Although erosion poses the main threat to the wreck, this effect diminishes with the amount of sand cover.

The Campsite Wrecks, Ebeltoft Vig (WGS84:N56.209491, E10.673205)

Although there has been some uncertainty about the exact number, at least three to four historic wooden wrecks lie within a $250 \mathrm{~m}$ square area off a beach. Known as the "Campsite wrecks", two have been investigated in a project involving amateur divers and museums. The area makes for an easy dive and no boat is necessary. Due to the shallow depth, i.e. two metres and sandy bottom, the wrecks are exposed to varying degrees.

The Spees, North Sea, Tannis Bay (WGS84: N57.723167, E10.495250) In 1697, the Swedish 48-gun man-of-war "Spees" became beached while escorting a fleet of Danish and Swedish merchant ships from England and France. She was carrying a load of spirit wine and pewter. When exposed by the current, the wreck is threatened by erosion and the degree of exposure varies considerably. The wreck lies at a depth of eight metres. NB: Always use caution and seek local advice when diving in the North Sea.

The wreck of the Disken (WGS84: N56.027962, E12.648271)

Dated by dendrochronology to ca. 1735, this wreck of a three-masted armoured trading vessel lying at a depth of 16 metres is very well preserved and has been investigated by the Viking Ship Museum in 2004. Although the Disken is threatened by erosion due to currents and shipworms (Teredo navalis) are present, much of the wreck is protected by sand. The wreck has lots of associated finds, which could be threatened from intensive diving. The site is only accessible with a large vessel. 


\subsubsection{Top locations for potential underwater trails: Norway}

The locations for potential underwater cultural and nature trails were compiled by Desiree Nævdal of the Maritime Museum of Norway, based on expert opinion.

The Grisefjorden Wrecks 1-6, Hollenderbyen, Flekkefjord municipality, Vest-Agder. (WGS84: N58.296523, E 6.661648).

The harbour area of Hollenderbyen (the Dutch town) has been used for commercial purposes several hundred years. This cultural environment has several interesting features both on land and underwater. The latter includes a traditional "skøyte", as well as several smaller wooden boats. The largest measures approximately $11 \times 3.5$ metres. The other vessels have yet to be examined. Wrecks 7 to 14 are located further out the seaway, where there also are several possibilities to make arrangements for divers and snorkellers. The site is well suited for divers and snorkellers in terms of accessibility. With a maximum depth of nine metres, a dive outside the quay is not particularly challenging or hazardous. The area lies within a river mouth, with a medium current: Sometimes the current may be stronger, but this effect is most marked at the surface. The seabed is covered with stones. The diving experience itself is fascinating, despite the poor visibility caused by the growth of algae. The site should be thoroughly examined before possible arrangements are made for divers. A cultural heritage sign should also be placed at the site in advance of any further developments.

Balsøya 1-11, Skien municipality, Telemark. (WGS84: N59.1202713, E9.5766303)

Balsøya has a natural harbor and a "ships graveyard" with 11 registered wrecks, the majority of which are presumed to be connected to the industrialisation at the end of 18th and the beginning of the 19th centuries. This area is quite spectacular area since most of the vessels are between 25-30 metres in length, while several are partly above the water line. The site is sheltered by the Balsøya headland. An underwater cultural heritage sign has been put in place, with a similar sign on land also. A plan for site maintenance and imparting knowledge has already been made, while collaboration between the Norwegian Maritime Museum and the municipality of Skien has already been established. One aspiration is to regulate an area for parking and to create a natural entrance to the site. The water in the area is brackish, which promotes the preservation of wood underwater as shipworm, i.e. the mussel Teredo navalis, appears only sporadically in pockets of saltwater.

The Langøysund wrecks, Nesodden, Langøysundet, Oslo municipality. (Approximate coordinates: WGS84: N59.871548, E10.725328).

In Langøysund Bay lies an unknown site close to the city center of Oslo, where during the establishment of a garbage deposit, five ships were dragged into the strait and submerged by the Oslo Municipality to prevent 
currents. Of these, three, i.e. the "Oscar" and "Jacoba" from Fredrikstad and “Anna”, out of Drammen were sunk in 1910, including two more in 1912. Photographs and documentation will be added to this document after an inspection, which will undertaken by the end of March, 2010. The site is well suited for divers and snorkelers, but a boat is necessary for transportation to the "Langøyene". There is public transport, i.e. ferry, during summertime. This site has been registered quite recently and therefore a thorough examination and documentation will be required before any arrangements are made for divers. Although diving in the area is not characterised as particularly challenging or hazardous, there is a general but incorrect understanding that diving is prohibited in the inner part of the Oslofjord.

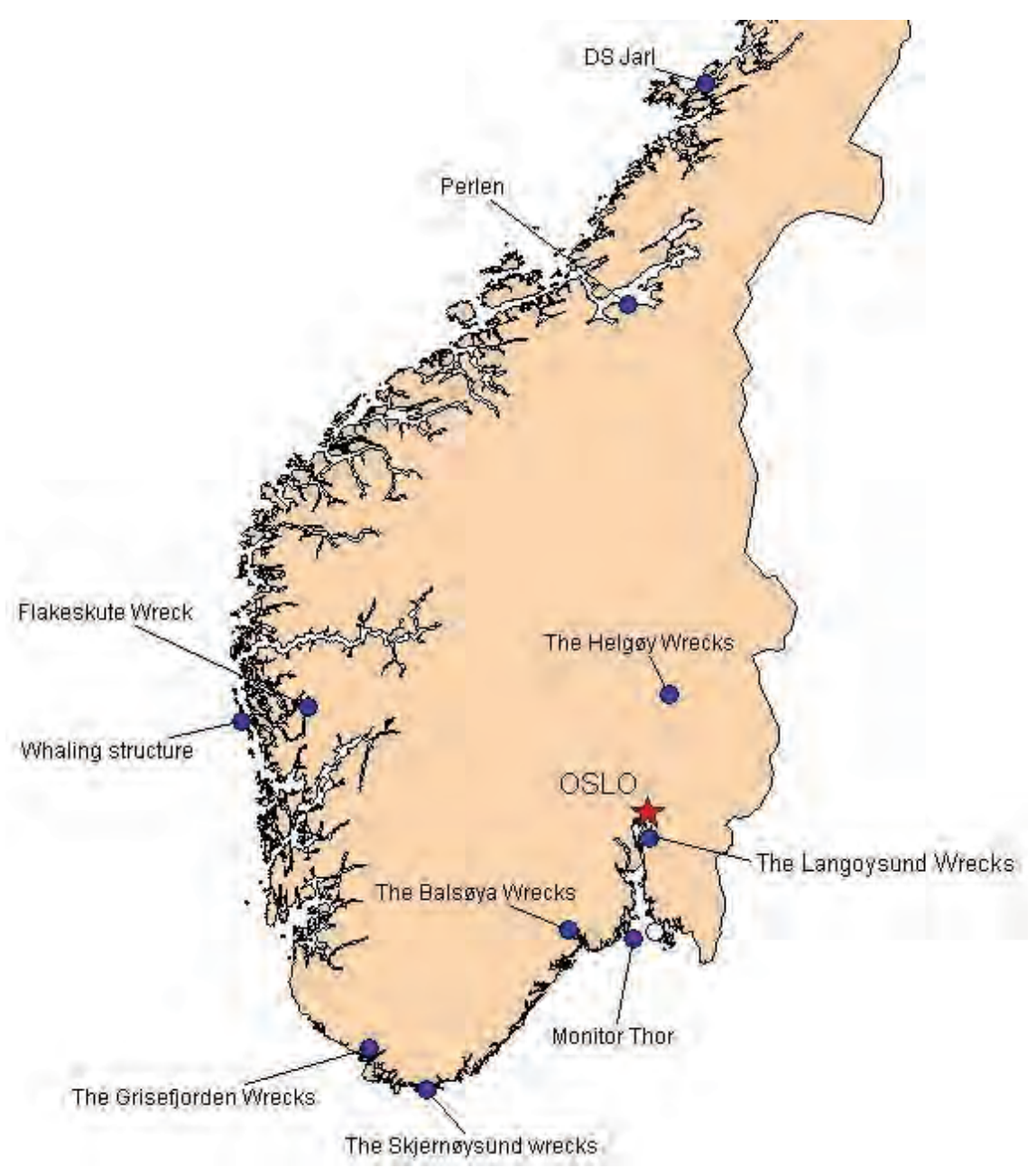

Top ten locations for underwater cultural trails as potential Norwegian Blue Parks.

The wreck of the monitor Thor, Bergevika, Ringsaker municipality, Hedmark. (WGS84: N59.053642, E10.5109207)

This vessel sank in 1918 during a storm while being towed to the scrap yard and now lies off the southwest shore of Hoftø Island, by "Verdens Ende” or "World's End”, near the Ferder Lighthouse in Vestfold. Built in 
1872, with a displacement of 2035 tons, this ship was designated as one of the largest monitors, or ironclad turreted warships in the world. This ship type emerged after the American Civil War. It measures 62.3 metres in length and 14 metres wide, with a freeboard height of only 0.5 metres. Although the number of crew was variable, she could operate with a maximum of 99 men. The bow and stern are the least destroyed and it is still possible to observe the tower with the canon and parts of the hull. The site is well suited for divers, but a boat is required to get to the wreck site. The wreck lies between 8 and 14 metres in an area that sometimes is strongly affected by weather. The site is already well known among divers and the Norwegian Maritime Museum has used the site for imparting knowledge for their maritime archaeology preparatory courses. There exists the possibility that this ship as an owner, so it will be necessary to make further investigations in advance of any possible arrangements being made for divers. The wreck is covered by a diverse and beautiful fauna, including soft corals (Alcyonium digitatum -“dead man's fingers”) and anenomes, such as the plumose anenome, Metridium senile. making the ship almost invisible. Therefore, it should be a relatively easy task to promote the wreck's biological characteristics for imparting knowledge to visiting divers.

The Helgøy wrecks 1-2, Bergevika, Ringsaker municipality, Hedmark. (WGS84 N60.7477031, E11.0165307)

Bergevika is an idyllic inlet on the island of "Helgøy", close to the town of Hamar. Since most of the shore along "Lake Mjøsa” is composed of shallow pebbled beach, this inlet is one of the few natural harbours for ships and boats. This cultural environment has several interesting elements on land and underwater, including a wreck, comprising a traditional "mjøsjakt", which probably is the "DS Styrbjørn”, which sank in the 1940's. Moreover, the wreck of another barge also lies in the vicinity. Both of these vessels are of significance for the local history in the area.

The barge can be seen in connection with transportation of building material taken from the ruins of Hamar cathedral, which were treated almost like a quarry for the rural districts after the fire in 1567 . This practice didn't end until 1844 when the ruin came under the protection of antiquarian authorities. The limestone kiln can also probably be seen in connection with this. Measuring 25 metres in length and 2.5 metres wide, the wreck of the "jekt" is located at the east of the inlet, with the bow rising 2.5 metres above the seabed. Most of the wreck has collapsed apaprt form this bow piece. Formerly steam-powered, the ship's machinery has been salvaged at some point.

The barge has a total length of 15 metres, is 5 metres in width and is buried deeply into the seabed. It was constructed with a ramp on the front of the stern, thus it was probably a ferry for the transportation of cattle or building material within the area. It is beautiful to dive on the outside of the southern 
cape, where there are several planes on the way down. It is most convenient to get there with a boat, because the distance from the two wrecks is quite far. The area is owned by the Ringsaker municipality. It is a popular place for swimming during the summer. Sign boards and benches are already in place. The site is well suited and already used by divers and snorkellers. The diving club: "Mjøsen (MDK)" could probably be involved in maintaining the trail. A dive in the inlet is not considered to be particularly challenging or hazardous. The site is situated within a national park. Therefore, it should be easy to find and promote biological characteristics for imparting knowledge in to snorkellers and divers via a trail.

The Skjernøysund wrecks 1-3, Skjernøy, Mandal municipality, VestAgder. (WGS84: Wreck 1 N58.0037838, E7.5122347; Wreck 2 N58.0049985, E7.5093759; Wreck 3(N58.0045064, E7.5133551)

Skjernøysund is a good starting point for several trails and parks. The island is centrally located in the archipelago, around which three wrecks are located. Of these, with its cargo of lime still in situ, Skjernøsund 3 may be singled out as suitable for arbitration.

Skjernøysund 1 is located at 9 metres depth and consists of the bottom section of a caravel built ship measuring 16 metres in length and 4 metres in width. There are several archaeological objects around the ship, so it is important that the site be thoroughly examined before possible arrangements are made for divers. In addition, a cultural heritage sign should be placed at the site in advance of further development.

Skjernøysund 2 is located at a depth of 4 metres and thus, would make a nice trail for snorkellers. It is an 11 metre long and 6 metre wide clinkerbuilt ship. Within the wreck lies a pile of ballast. Several artifacts surround the ship, which need to be recovered to the museum before possible arrangements are made for divers and snorkellers.

Skjernøysund 3 is a 15 metre long clinker-built ship located at 5 meters depth. Within the wreck is a lime mortar cargo which probably has been approximately 10 barrows. The wreck is highly exposed to shipworm, such that large parts off the hull and most of the barrows have already disappeared. 


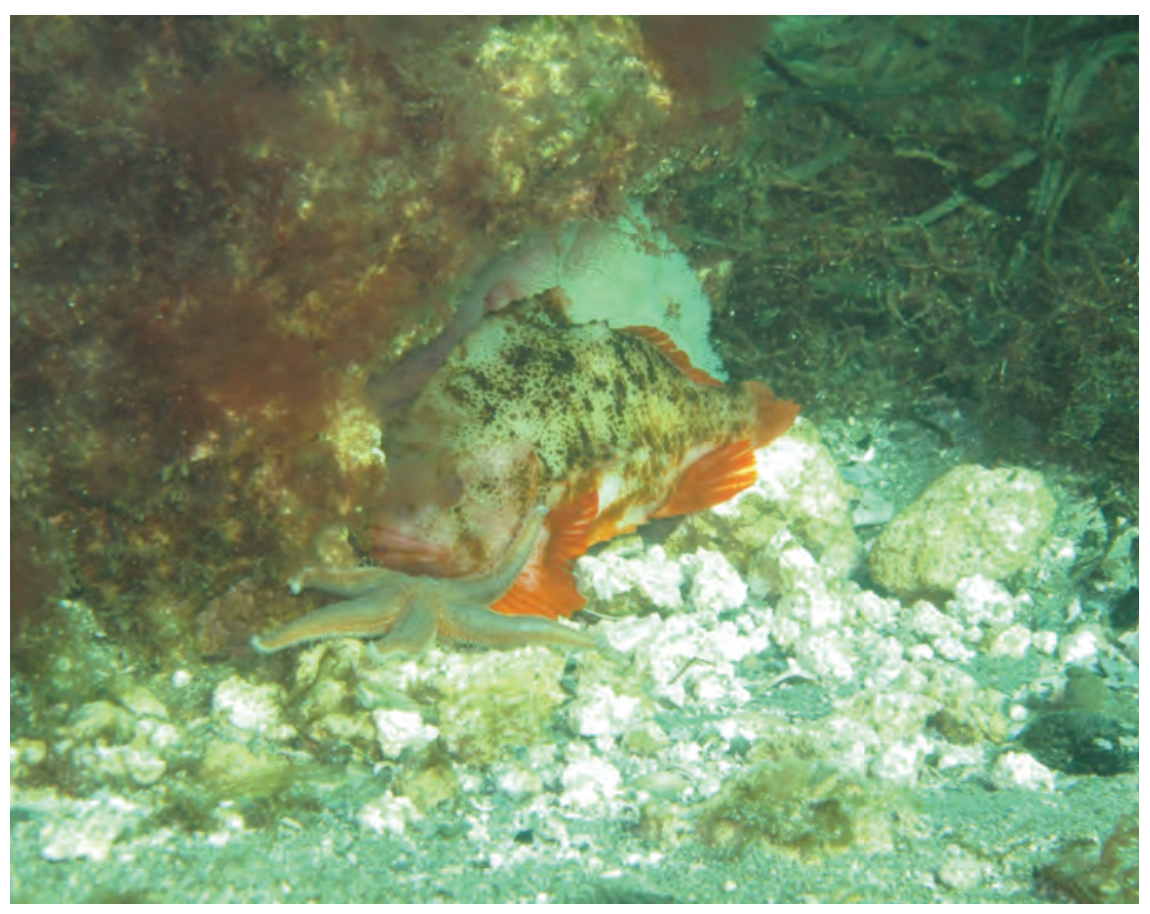

Lime mortar cargo from Skjernøysund 3

The site is well suited for divers and snorkellers. It is already used frequently by the diving club from Mandal and others. Before arrangements are made for divers, there needs to be an investigation to test the vulnerability of the wrecks. A cultural heritage sign should be placed at the site in advance. There is a strong local aspiration, mainly from the divers club, to get to use this wrecks for imparting knowledge. A dive in the area is not characterised as being challenging or hazardous. The site is situated within a national park, therefore it should be relatively easy to find interesting biological characteristics for imparting knowledge in an underwater trail.

The wreck of the Perlen, Trondheim municipality, Sør-Trøndelag (WGS84: N 63.4541028, E10.4354101)

The wreck site of the frigate "Perlen" is located close to a place called "Ladehammeren", which is mentioned in several written sources back to medieval times. Originally named the Delamere, the ship was built in England and sank in 1781. When the site was excavated in 1975, construction materials, including yellow tile from the Netherlands were found. There are also other underwater wreck to see in the vicinity: a barge, a ferry and an aeroplane. 


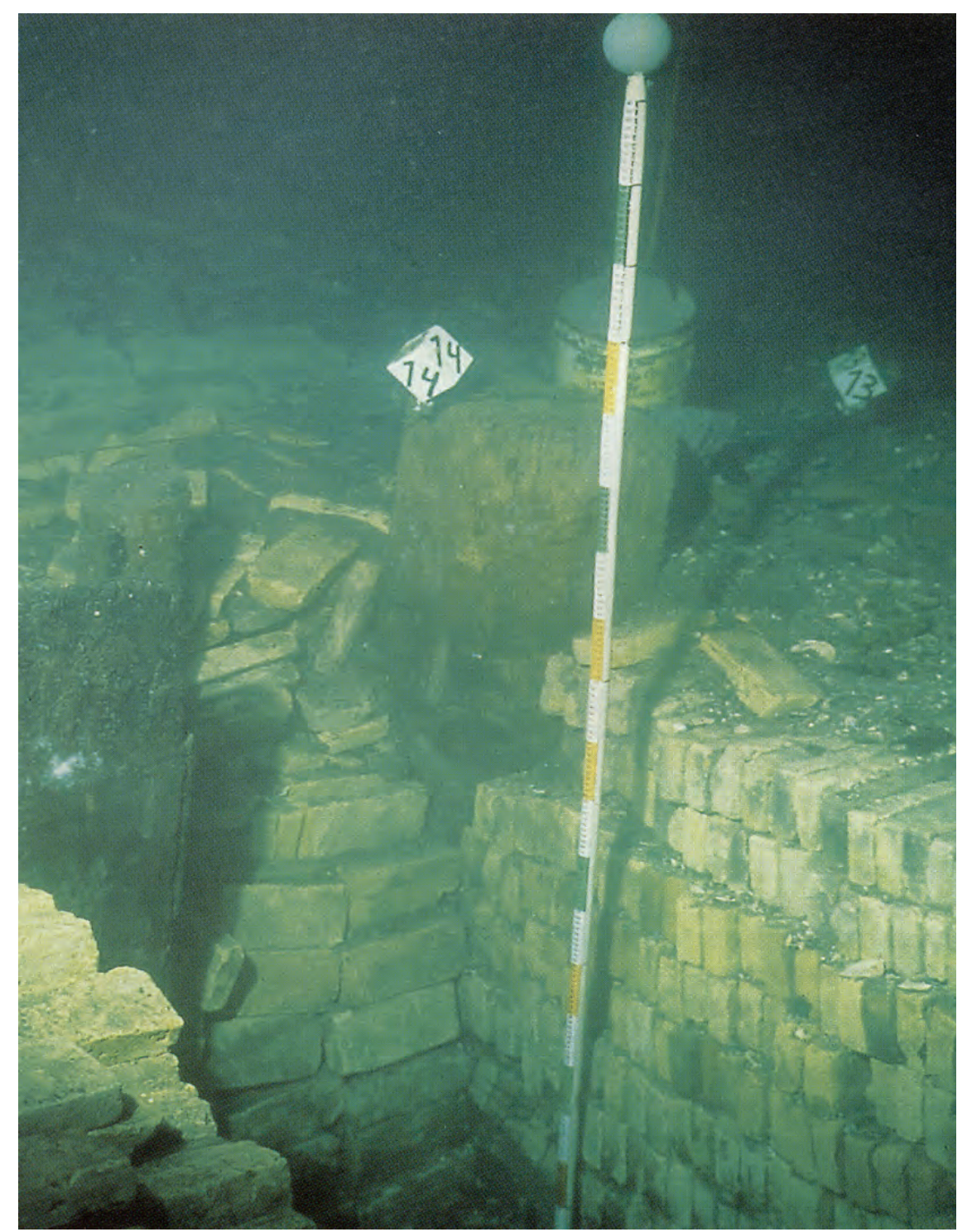

Underwater photo from the wreck of the "Perlen", showing the cargo of Dutch tiles.

The site of the main wreck is quite flat. Nearby there is a stone wall (Kjerringberget) 20 metres down to the seabed. A cultural heritage sign is already placed under water here and there is a supporting diving club who probably wants to contribute to place "their wreck" on the map. The Museum of Natural History and Archaeology (Vitenskapsmuseet) in Trondheim has the documentation from the excavation and are also responsible for maintaining the wreck. Underwater environmental features include a sandy seabed. Perlen lies within 500-600 metres from Korsvika inlet, which is considered to be quite polluted. 
DS Jarl, Rørvik, North-Trøndelag. (WGS84: N64.9779499, E11.5543893)

This wreck site at Ivarholmen outside of Risvær at Vikna dates from the 17th of March, 1950, when this steamer sank on the way from Florø to Bodø with a cargo of fish. A boat is necessary to reach the site and the dive can be quite challenging with waves and currents. It is possible that this ship has an owner, so it will be necessary to investigate this in advance of possible arrangements being made for divers. A underwater cultural heritage sign has already been placed here, with support from the local diving club "Folla", which would probably contribute to putting "their wreck" on the map. The Museum of Natural History and Archaeology (Vitenskapsmuseet) has archive information about the wreck.

Whaling construction, Herdlevcer, Øygarden municipality, Hordaland. (WGS84: N60.5622000, E4.8252820)

This construction lies within an area that has historical references going back to medieval times. This has been a seasonal settlement for fishermen, probably lying within the kings farm Herdla in the Viking ages. There is a lookout post further south in the strait. The construction is in a sheltered location at 5 meters depth, where it was supposed to close the strait, making the hunt easy for the whalers. Unfortunately, this construction has become part of the foundation of a modern road. The site lies along the "North Sea trail", which is a popular hiking trail along the spectacular coastal landscape.

\section{Wreck of a "flakeskute", Skipshelleren, Vossavassdraget, Vaksdal} municipality, Hordaland. (WGS84: N60.6531970, E5.7942260)

At this site is a wreck of a traditional vessel known as a "flakeskute", which is an expression from Bergen, describing a transportation vessel with a roof. This particular vessel was probably used for the transportation of grain at the end of the 18th century. Two smaller boats lay partly within this larger vessel. The site is located within "Straume Landskapsmuseum" which is a Stone Age settlement dating from $6000 \mathrm{BC}$. Vossavassdraget is the name of the watercourse and here one will find several ship wrecks. This particular area has a rich history in industry and transport because it lies on the main shipping lane between Voss and Bergen. In addition, timber was transported here from the more rural districts. The name "straume" means current, which can occasionally be quite strong around this area. Nevertheless, this site lies within a bay, close to the shore, making it suitable for snorkelling also. Accesibility is also enhanced because of the nearby landscape museum. Although the site lies within the lee of a sheltering headland known as a "heller", the surroundings are more beautiful further out. 


\subsubsection{WP 2-Pressure \& Threat Assessment}

This work package builds on existing pressure and treat assessment lists (matrices), e.g. identified by the EU's Marine Strategy Framework Directive 2008/56/EC, UNESCO's Intergovernmental Commission (Ehler \& Douvere, 2009) and the Marine Life Information Network (MarLIN), covering natural and anthropogenic pressures and threats. The third pressure evaluation method derives from the BALANCE project (www.balance-eu.org).

\subsubsection{Risk Matrices}

From the available literature for existing examples of risk/threat matrices, three were found to be useful. The first, taken from an International Oceanographic Commission (IOC) report for UNESCO by Ehler \& Douvere (2009), comprises a comprehensive matrix of human use conflicts and compatibilities. A simplified version of this matrix table can be seen in Table 4. From this table we can generally see that setting up underwater trails and such activities do not generally go well with other, more traditional, industrial, maritime or military uses of coastal and maritime areas.

Moreover, the categories are relatively vague when compared against each other. Similarly, using a matrix comparing coastal activities to environmental factors from the Marine Life Information Network gives three general reference categories, i.e. a possible effect, a probable effect, or no effect at all! More detailed information on MarLin can be found at the following web adress: (http://www.marlin.ac.uk/PDF/activities3.pdf)

Table 4. Human use conflicts and compatibilities (modified from Ehler \& Douvere, 2009).

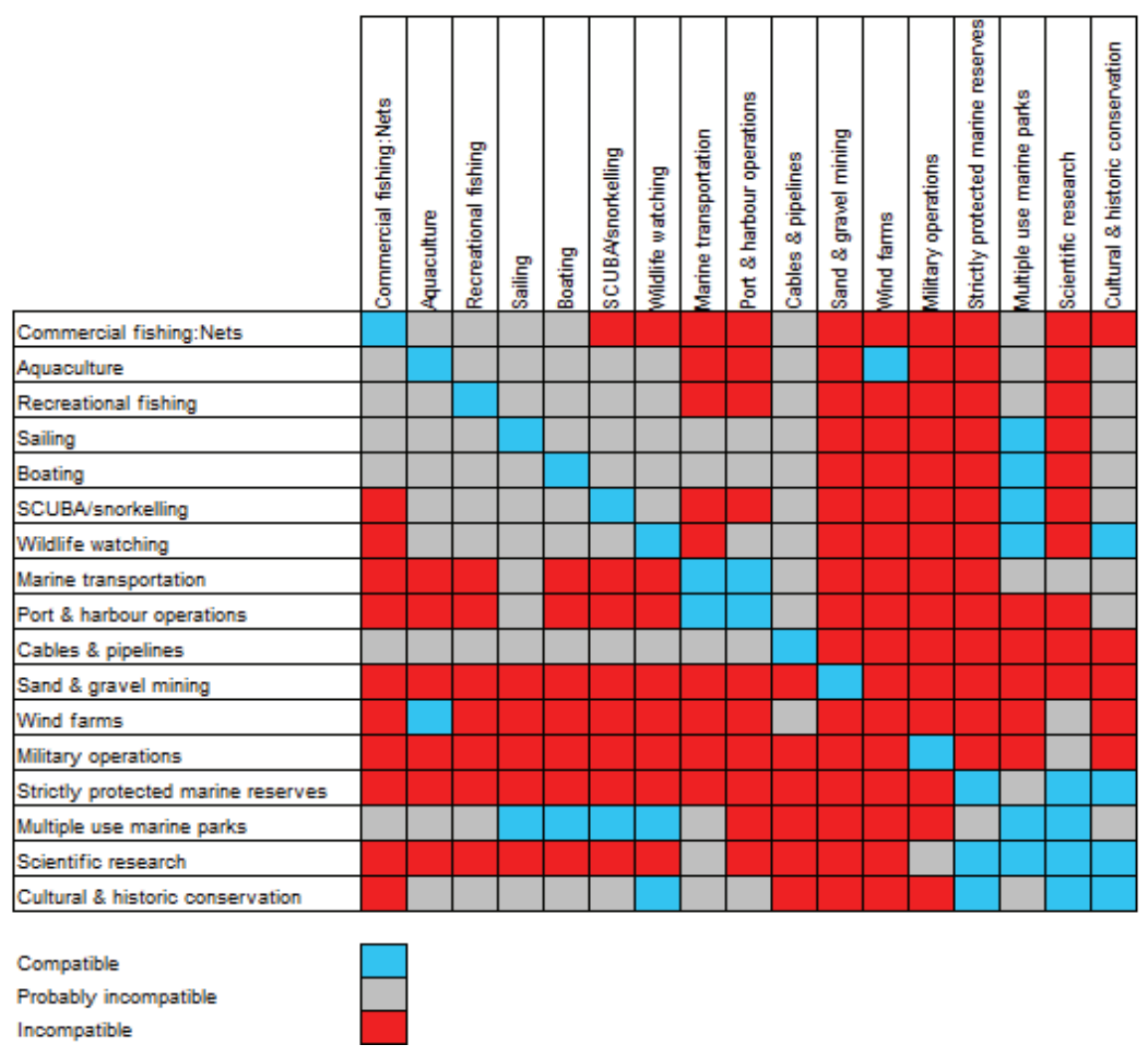


The third pressure evaluation method derives from the BALANCE project (www.balance-eu.org), in which the authors attempted to construct a meaningful pressure evaluation cards (PEC) and matrices (PEM), which can be used in marine spatial planning. A "Pressure evaluation matrix (PEM)" is a collective name for a spreadsheet template that makes it possible to compare the relationship of various categories of marine biodiversity versus human activities (i.e. potential pressures) and their degree of impact on the biodiversity (BALANCE report). This report presents a holistic approach to marine spatial planning taking both human uses and environmental information into account, while operating within the multinational context of the Baltic Sea Region. The BALANCE approach is built around three key elements:

- The combination of ecological information with information of multiple human uses, pressures and impacts

- a spatial planning template describing the steps towards marine spatial planning

- a simple, balanced zoning approach allowing space for all human uses, while minimising the impact on the marine environment

Examples of how to construct a Pressure Evaluation Card are given in the BALANCE report. Here, the report looks at the pressures and effects induced by net fishing, sand and gravel extraction and the construction and operation of wind farms. In addition, human pressures on specific habitats recognised by the Natura 2000 Habitats/Habitat Directive list (submerged sandbanks, inlets and bays), as well as specific species, i.e. the seagrass, Zostera marina. In this way, the authors proposed the construction of comprehensive information about seabed landscapes, coastal landscapes, habitats and even individual species. Each of the pressure evaluation cards is constructed and filled in under the following basic headings:

- Background information

- Environmental impact of the activity

- Spatial scale of the impact

- Affected habitats and species

- Timescale of the impacts

- A summary ranking/evaluation of pressure by different authors, including a list of the source literature

For a particular species, additional headings include characterising species, natural distribution, typical habitat, possible reasons for a change in abundance, biological relevance, potential threats and the spatial scale (maximum distance) at which they may have an affect, etc. 
Finally, a synthetic evaluation is made based on the above, comprising five categories, Insignificant, Low, Moderate, High and Severe. This evaluation is then inserted into a pressure evaluation matrix (PEM).

In light of the Nordic Blue Parks project to promote underwater heritage, a new matrix table was constructed to compare different risk/threat factors, i.e. environmental and anthropogenic, against the impacts, risk levels and maximum distances affected (Table 5) on underwater nature and cultural trails. Threats were assigned five category levels: Insignificant, Low, Moderate, High and Severe, as above. In addition, we also used the same approximated maximum distance effect categories: Insignificant, Point-source, Short, Intermediate and Long. Moreover, we also cut down the number of human activities for ease of use. For example, the matrix used by the Marine Life Information Network (http://www.marlin.ac.uk/PDF/activities3.pdf) and in the BALANCE report used eight and eleven sub-categories respectively for the activity "Fisheries". In our matrix, this was reduced to one category, i.e. "Fishing/fishing nets". The various risk types fell under two broad categories, i.e. environmental and anthropogenic, which themselves were subdivided into physical, chemical and biological in the former and unintentional and deliberate in the latter.

\subsubsection{Environmental risk/threat factors}

There are many factors affecting the condition of a wreck. These include:

- The nature of the shipwreck, e.g. storm, battle, etc.

- How the ship was built

- Its condition at the time of the shipwreck

- How long it has been submerged

- Environmental factors

It should also be recognised that a wreck itself may pose an environmental threat due to its cargo. For example, in Finland, the wreck of the Vrouw Maria probably has mercury in her cargo hold (Tikkanen, pers. comm.), while more recently; ships sunk during World War 2 contain explosives. The various environmental variables were divided into three categories, i.e. physical, chemical and biological risk factors.

Physical risk factors

Currents and waves

These cause erosion and removal of sediments, which can negatively affect aquatic vascular plant communities by removing their anchoring substrate. They are generally of low importance for underwater nature trails and depend highly on their location. Problems can be avoided by proper site selection. For wreck/cultural sites, current and wave-induced mechanical erosion and the removal of protective sediments exposes the site to oxygen-rich water, as well as moving loose artefacts. The risk level is dependent on both 
the depth and location of the wreck, with deeper sites less affected by current or wave action. As risk factors, currents and waves tend to be location dependent for both cultural and nature trails, thus we considered them to have an intermediate distance effect (1-10 km).

\section{Sedimentation}

In the Baltic Sea, sedimentation is faster than in many other seas, e.g. up to 0.05-1.94 cm per year in the Gulf of Finland. There are also undisturbed sediment layers with only little oxygen and few infaunal organisms. Artefacts are best preserved when buried deep in dense silt. Sedimentation occurs naturally due to the introduction of material by rivers or through currents or waves during storms. Sedimentation can result in smothering certain filter-feeding organisms, which may be replaced by detritus feeders, as has occurred in the Finnish Archipelago Sea (Leppäkoski et al. 1999). Sedimentation effects depend on the quantity and duration of material being deposited and are considered a minor risk. For underwater cultural site sedimentation may serve to protect an artefact or structure by isolating it from oxygenrich water, creating various oxidation-reduction conditions and by preventing mechanical erosion. Sedimentation poses a variable risk level, depending on the quantity/quality of bottom sediments and current strength. Sedimentation may be considered to affect underwater trails over a short distance only.

\section{Sea ice}

The shallow Baltic Sea has weak currents and freezes easily because of low salinity. For example, permanent sea ice cover along parts of the Finnish coastline may exceed 100 days (Seinä \& Peltola 1991). Thick pack or drift ice may mechanically damage sites by removing overwintering vegetation or by scraping the seabed in shallow water. Similarly, trail information plates, guide ropes and buoys need to be removed from shallow areas in winter to prevent damage. Nevertheless, sea ice is considered a moderate risk for underwater nature trails. By contrast, sea ice poses a significant risk for wrecks lying in shallow water, while those lying in deeper water are much less affected. Therefore, this risk factor was considered to have a point-specific (wrecks) to short distance (biota) effect. 


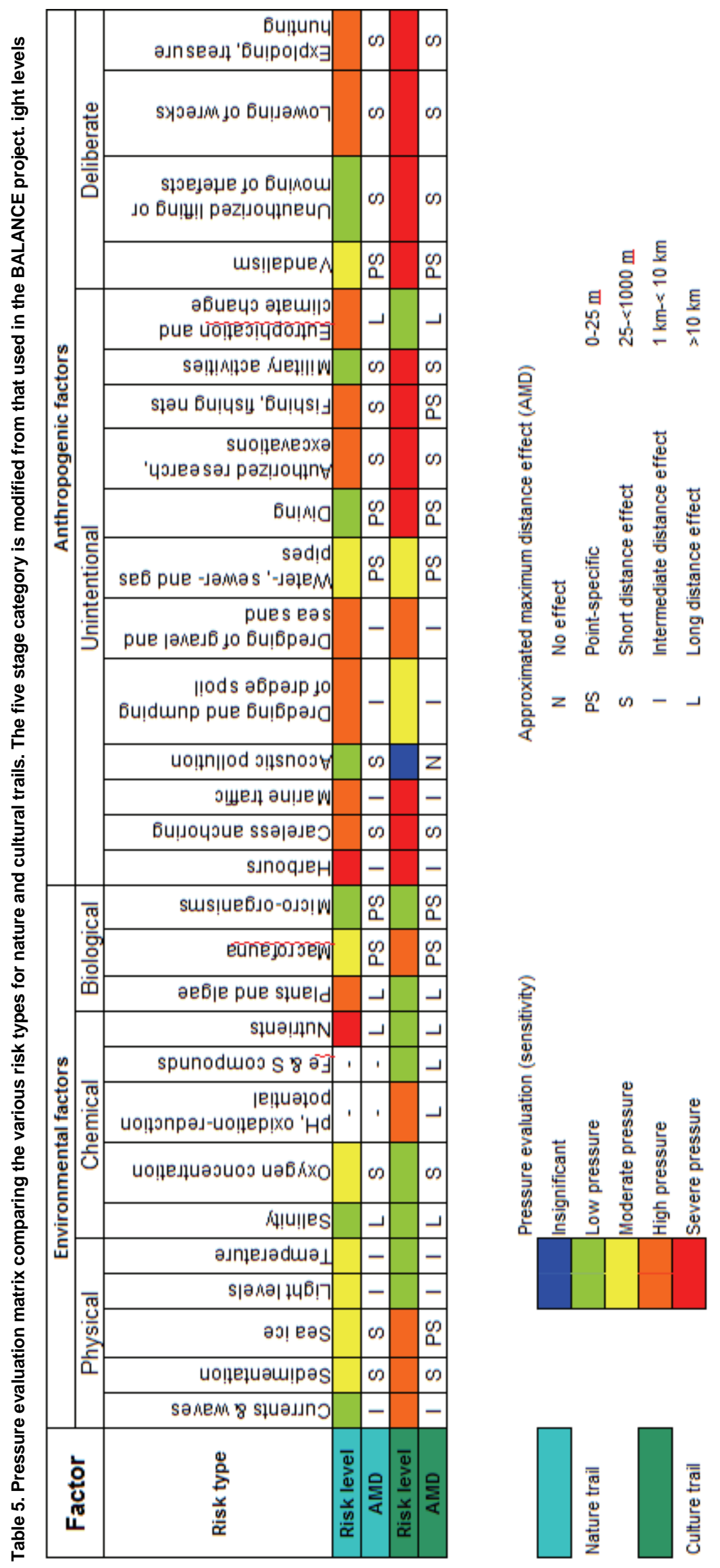


Phytoplankton generally occurs at its most dense between the surface and approximately 10 metres, which may impact greatly on visibility. The density of solid matter and the water becoming turbid depends on the concentration of the sediment at the bottom, currents, temperature and salinity. In southwestern Finland the amount of daylight varies up to $80 \%$ depending on the time of the year. Climate factors, the amount of melting snow, sea ice and the level of phytoplankton blooms can have an effect on the amount of daylight. Lowered light penetration limits the depth ranges of aquatic plants, reducing their depth range distribution, or may result in the loss of species entirely, thus lowering the biodiversity. While light levels are affected by sedimentation and phytoplankton blooms, for nature and cultural trails they are considered a moderate and minor risk, respectively, and affect underwater trails over intermediate (1-10 km) distances.

\section{Temperature}

The water in the deeper parts (i.e. below 20 metres) of the Baltic Sea may be cold all year round. However, in shallower depths, the water is at it's warmest in summer. This may be pleasant for snorkellers and swimmers but the capacity of warm water to hold dissolved oxygen is reduced, compared to cold water. In eutrophicated waters, this may effect biota with already reduced oxygen levels and may be cosidered a moderate risk (O’Brien et al. 2003). While warmer water will acelerate chemical reactions which may cause the destruction of wrecks, temperature changes are only a low risk for artefacts lying in deeper water below the thermocline because it prevents cold bottom water from mixing with warmer water near the surface. Although vertical distances in temperature may operate over short distances for underwater trails, horizontal distance effects can be found over a larger scale, i.e. intermediate distances.

\section{Chemical risk factors}

\section{Salinity}

Low salinity in the Baltic Sea, particularly in the eastern and northern reaches, causes reduced species biodiversity (Laine et al. 1997). However, such conditions promote the preservation of wooden wrecks due to its being unfavourable for the shipworm (Teredo navalis). Salinity changes in such areas are considered a low risk for both endemic underwater nature and submerged artefacts, as metal objects corrode very slowly in such conditions. For example, salinities range from 2-3 PSU in the Gulf of Bothnia. However, at higher saline levels, metals corrode quickly, posing a moderate/significant risk. In such conditions, cathodic protection, i.e. using a sacrificial zinc anode, can be used for in situ conservation of metallic artifacts. For both types of underwater trails, salinity can be seen to have a long distance effect $(>10 \mathrm{~km})$. 


\section{Oxygen concentration}

In shallow waters, low oxygen levels are considered a moderate risk for biota, with occasional deoxygenation occurring in deeper water leading to the build up of sulphur bacterial mats. Oxygen content may also be reduced in shallower water by the explosive growth of filamentous algae. Rotting drift algae will also consume oxygen (Vahteri et al. 2000). For submerged wrecks, oxygen-rich water promotes the corrosion of metals as oxygen accelerates the oxidation reaction. However, corrosion can also happen under anaerobic conditions. On wrecks, in situ anoxic/hypoxic conditions also affect those organisms responsible for destroying organic materials. Pressures incurred due to oxygen concentration levels are generally considered to have a short distance effect in shallow waters, but effects may be more long distance in the deeper waters of the open sea.

\section{Oxidation-reduction potential/pH}

Changes in $\mathrm{pH}$ are considered a high level threat to submerged sites. $\mathrm{pH}$ affects the solubility of many substances as well as the speed of biological processes. For example, faunal textiles and pollen thrive best in a slightly acid environment, while glass, metals, slag, bone and floral textiles are best preserved in alkaline environment. Further, a low $\mathrm{pH}$ decomposes cellulose and weakens wood. Therefore, wooden structures are best preserved in reduced conditions. Linked with oxygen concentration, the $\mathrm{pH}$ and redox potential may have short to long distance effects, depending on location and depth.

\section{Nutrients}

Eutrophication is perhaps the biggest ongoing environmental problem in the Baltic Sea comprising moderate to significant risks for biota (Cederwall \& Elmgren, 1980; Bonsdorff et al. 1991; Wulff et al. 1994) Nutrients lead to the explosive growth of filamentous algae to the cost of key macrophyte algae species such as bladderwrack, Fucus vesiculosus, as well as other vascular plants (Rönnberg 1985) This causes a loss in biodiversity, as well as a reduction in available oxygen for other flora and fauna. When these mats begin to rot, they also consume oxygen from the water column and are anoxic underneath. Once anoxic conditions are reached, all flora and fauna die and mats of sulphur bacteria form.

In the Baltic Sea,the most important nutrients are salts of nitrogen and phosphorus but also of sulphur and also iron. While nutrient inputs may have a point-source effect, e.g. from a sewage leak or fish farm, these effects diminish with distance. By comparison, high background levels of nutrients may derive from long distance sources. Iron- and sulphur compounds: On the seabed, iron and sulphur compounds penetrate into artefacts and make their conservation more difficult. This is a low risk while still in situ which becomes significant because when artefacts/structures are lifted to the surface, reduced sulphur compounds react with oxygen and oxidize to sulphuric 
acid and on drying out they form solid salts. Iron ions in the wood catalyse this oxidation reaction. The formation of acid reduces the $\mathrm{pH}$, which decomposes cellulose and weakens the wood.

\section{Biological risk factors}

\section{Flora}

Plants and algae stabilise sediments and promotes sedimentation, thus protecting a site from waves and erosion. However, if certain species overly dominate, such as filamentous algae, they can completely cover and outcompete endemic key plant species. This can reduce the overall biodiversity and attractiveness of a site. When plants and filamentous algae die and decompose, they absorb all available oxygen, kill benthic organisms and lead to the build up of algal mats (Vahteri et al. 2000). Under such conditions they may pose a high risk. Plants may completely cover a wreck site. Although decaying algae may affect the preservation of a wreck, the threat posed is considered to be low. Plants and algae are considered to have a long distance effect over horizontal distance, but may be limited vertically, depending on other factors such as light levels, oxygen concentration and temperature.

\section{Fauna}

The Baltic Sea is generally species poor due to low salinity. However, the abundances of certain species may be locally high and/or may dominate over intermediate to long distances. Because of the prevailing conditions and the increase in shipping traffic, it is possible that new invasive species will be accidentally introduced which may upset the ecological balance by outcompeting the native species (Baltic Sea Alien Species Database- http://www. corpi.ku.lt/nemo/). Depending on the proximity to harbour areas, invasive aggressive species may pose a moderate risk. Thus, invasive species tend to have a point source distance effect. However, if they successfully colonise the new habitat this distance effect may well increase. For submerged wrecks, the shipworm, Teredo navalis and similar boring organisms destroy wood in saline areas (high risk) but cannot survive in brackish conditions. Benthic organisms may either help or diminish the burial of the site and may change the stratigraphy of the area and affect on the chemical composition of the sediment.

\section{Micro organisms (fungi and bacteria)}

As mentioned above, in hypoxic and anoxic conditions, sulphur bacteria form mats on the soft seabed. Further, rotting filamentous algal mats are decomposed by bacteria and consume oxygen at the sediment-water interface. Depending on the size and duration, these features may pose a low to moderate threat to benthic infauna, exhibiting a point-source maximum distance effect. Micro-organisms also pose a low to moderate threat to submerged wooden objects. Erosion bacteria occur in anaerobic conditions and 
destroy cellulose and lignin in wrecks (Kinnunen 2008). Soft rot fungi can also attack wood cellulose and lignin. Although the wood still looks normal, when cellulose is destroyed, its structure is weakened. Thus, bacteria form a point-source maximum distance effect on wrecks.

\subsubsection{Anthropogenic risk/threat factors}

Threats and risks due to human activities were divided into two categories, i.e. unintentional and deliberate.

\section{Unintentional activities}

\section{Inadequate legislation}

Sites can be protected with adequate legislation. For example, Finland has quite a functional legislation, i.e. the Antiquities Act (295/1963), which has been particularly updated in the 21st century.

\section{Harbour activities}

Industrial development in the coastal zone, collisions, pollution, wave and noise disturbances may severely affect the biota close to a harbour and may cause damage to shipwrecks and underwater structures. The level of risk to submerged artefacts depends on the site's location. Therefore, harbours may be considered to exert up to an intermediate distance effect (1-10 km).

\section{Careless anchoring}

This activity damages the seabed and plant communities, e.g. seagrass meadows (Zostera marina: BALANCE report; Boström 2001) causing fragmentation and habitat loss and constitutes a high to severe risk. Careless anchoring damages wreck structures and is considered a severe threat, particularly to shallow-lying wrecks. Damage can be avoided by providing information to the public and putting anchoring buoys in place. This activity generally constitutes a short distance effect, i.e. 25-1000 m, for both types of underwater trail.

\section{Marine traffic}

Marine traffic can cause oil- and other accidents, including waves. Other considerations include gas emissions from motor engines, chemical releases from antifouling paints. The release of bilge and sewage water from pleasure boaters is also a concern. Depending on location, marine traffic, particularly from larger vessels, may create moderate to high pressure on biota. The waves and propeller wash caused by large ships can affect to a depth of 8 metres. Such water movements may pose a severe risk if a wreck site is located on or near a shipping lane. Therefore, some effects experienced by underwater trails due to marine traffic may be have an effect up to intermediate distances (1-10 km). 


\section{Acoustic pollution}

Engine noise causes disturbance above and below water to biota, particularly cetaceans, seals and birdlife and may be considered harmful in areas of regular, heavy maritime traffic. Considered a low threat. By comparison, for wreck this risk is considered insignificant. It is difficult to assess the maximum distance effect of acoustic pollution on biota. For example, the impact may be insignificant or point source on benthic macrofauna, while effects may operate over intermediate to long distance effects in higher animals like seals and whales

\section{Dredging and dumping of dredge spoil}

Fine sediment material released during such activities, particularly in large quantities cause a reduction in water visibility. Long-term, such material clogs filter feeding species, which may be replaced by detritus feeders, or all fauna becomes smothered (Kauppila \& Wright, 1997). Wrecks may suffer physical damage from the dredger or may become buried in fine material released during dredging. Material dredged from harbour areas may contain contaminants such as heavy metals, nutrients or other pollutants. These threats may pose a high risk to biota and a moderate risk to wrecks. The distance effects depend on how fine the suspended material is, as well as currents. Thus, such activities may have an effect up to intermediate distances.

Dredging gravel and sea sand for the building industry

Similar distance effects to those described above. May also involve the removal of habitat. Considered a high level threat to biota and a high to severe level threat to wrecks, particularly to those lying on shallow level sandy seafloor areas.

\section{Sewage, gas and oil pipelines}

These conduits may leak causing pollution and pose a moderate risk for both biota and wrecks. Although maximum distance effects will vary depending on the size, duration and quantity of the leak, the effects are mainly considered to be point-source.

\section{Diving}

The removal or collection of target species through such activities as spear fishing or shellfish collection generally poses a low threat to underwater biota. Divers' breathing air and the disturbance of bottom sediments or material covering the wreck may affect the resident fauna. Moreover, divers may loosen the protective sediment crust which poses a moderate to significant risk for metallic artefacts. In addition, there is a severe risk due to unintentional wear and tear on wrecks and artefacts caused by divers grabbing, holding and touching the wreck or by careless movement due to poor buoyancy control. (Jim Hansson. MACHU project, Final Report: 
www.machuproject.eu). Distance effects are very short, i.e. point-source (0$25 \mathrm{~m})$.

\section{Authorised research/excavations}

Excavations will always damage the site. The protective layer of sediment is removed and the artefacts and/or structures may be damaged as they are lifted to the surface. If the wreck is completely excavated or lifted, such actions form a significant risk to the wreck itself. It may also destroy the living environment of the flora and fauna, forming a high to severe risk due to sediments being resuspended, causing filtering organisms to be smothered. Maximum distance effects are probably relatively short, i.e. 25-1000 m.

\section{Fishing/Nets}

Loss of nets and gear may be hazardous to divers, shipping and animal species. Trawling damages the seabed causing habitat loss and target and nontarget species removal, comprising a high level threat. Wrecks and other submerged structures may be snagged, removed or destroyed in fishing nets, which pose a signifcant risk. Approximate maximum distance effects are generally either point-source in the case of wrecks or static nets. However, mobile net fishing can cause scarring of the soft sea bed, habitat loss, sediment resuspension and smothering effects on benthic fauna over short distances (BALANCE report- www.balance-eu.org).

\section{Military activities}

Underwater explosions of old mines and war wrecks, artillery exercises and naval manouevres are often conducted in specific military zones, which are restricted to the general public. Therefore, they pose only a low risk to biota. By comparison, such underwater activities may comprise a severe threat to submerged structures. For example, underwater explosions may destroy the wrecks. Although wrecks have been destroyed by exploding in Finland, the Antiquities Act (295/63) protects those wrecks over 100 years old. This however leaves more recent wrecks without protection. Moreover, after the World War II, more than 40000 tons of chemical weapons have been submerged in the mainly southern parts of the Baltic Sea. These chemicals may yet pose a severe threat to all forms of underwater life. While naval exercises and underwater explosions may have short to intermediate distance effects on the underwater biota and wrecks alike, chemical weapons hold the potential for severe and long lasting point-source effects. For further information visit www.mil.fi

\section{Eutrophication/climate change}

The level of eutrophication has dramatically increased in the Baltic Sea due to the introduction of nutrients from a wide catchment basin. Effects such as reduced visibility, loss of biodiversity, hypoxia, sulphur bacterial mats, in- 
vasive species and an increase in sedimentation levels poses a severe threat to flora and fauna. These risks are less clear for submerged shipwrecks and artefacts. As mentioned above, eutrophication may pose either point-source or long distance effects, depending on the source of the excess nutrients. Similarly, climate change acts over long distances.

\section{Deliberate activities}

\section{Vandalism}

Problems include dumping litter, sewage, bilgewater, as well as noise pollution and disturbance pose a low to moderate risk for biota. By comparison, such activities, including the damage of wrecks and deliberate removal of anchoring buoys constitute a significant threat for wrecks. Better education programmes to positively influence attitudes are considered the best method to counteract vandalism. The effects of vandalism are generally considered as either point-source or short distance.

\section{Unauthorised removal of objects}

The illicit removal of loose artefacts is considered a significant risk for wrecks. Fortunately, the level of diving education is quite high nowadays, with divers urged to leave loose artefacts where they are so that other people can also enjoy them. As with vandalism, improved education programmes to positively influence attitudes of divers are considered the best way to counteract looting. If the objects removed are small, this activity has only an insignificant to low pressure risk for biota. However, if large objects, i.e. wooden beams, etc., are removed, the disturbance of the seabed may cause sediment resuspension, smothering of fauna, as well as habitat removal. This activity is considered to have only a point-source maximum distance effect for both biota and wrecks.

\section{"Lowering" of wrecks}

When a wreck is either at the surface or lies in shallow water, it endangers marine traffic and needs to be moved to deeper water. This may create a significant threat to the wreck depending on the method used to move it, i.e. by physically dragging it or through the use of explosives. Similarly, the method of removal may also pose a high risk to the flora and fauna associated with the wreck because biota that can survive in shallow waters may be unable to do so at depth. Further, if the substrate is removed through explosion, the artificial habitat is removed and biodiversity is reduced. This activity is considered to have only a point-source or at most, short maximum distance effect for both biota and wrecks.

\section{Exploding, treasure hunting}

Treasure hunters and looters are only concerned for the valuables contained within a wreck, such that remaining artefacts and other historically important structures are destroyed. Such activity comprises a severe threat to sub- 
merged wrecks and a high level threat to associated biota also, as described above. This activity is considered to have only a point-source or at most, short maximum distance effect for both biota and wrecks.

\subsubsection{WP3-General Principles for Management Guidelines and Criteria for setting up a Blue Park}

We created general principles for the management guidelines of Blue Parks and Blue Trails based on the experiences from case study sites, and where possible, from one cultural and one natural site and/or trail in each of the four project member countries. Here, we define the principles for using the terms Blue Park and Blue Trail (what is generally offered to the visitor (infrastructure, facilities, information), the security rules (no hunting or net fishing allowed, no looting, diving security and principles, rescue plans). We also define the general principles for the Blue Park management, i.e. we define what the management guidelines should include and demonstrate this by providing a first set of basic guidelines (but not official management plans, or detailed guidelines, since these are outside the scope of a project of this size).

Tourism has become an increasingly complex phenomenon, with political, economic, social, cultural, educational, bio-physical, ecological and aesthetic dimensions. Considerable planning is required before starting an underwater park. One of the aims of the Blue Parks project is to establish a management perspective and to find those best practices to create a tool for affecting higher administrative and decision-making levels. Through the various methods from low- to high-tech, a set of criteria can be compiled for making recommendations when it comes to setting up further blue parks and trails. The following paragraphs are a compilation of ideas and experiences gathered during preparations for the Blue Parks to be opened in the various member countries.

\section{Endurance}

The challenge is to create a long-lasting Blue Park, which combines underwater natural and cultural heritage,one that will remain attractive beyond its first season, and not languish because of other priorities and goals.This requires dedicated entrepreneurs, healthy finances, including political enthusiasm and involvement.

Pre-survey and documentation level

A thorough survey and status assessment of natural and cultural heritage must be performed before opening a Blue Park. There is no clear example on how well the site should be documented before setting up a park. Ideally, the site should be sufficiently documented so that new research would not necessarily bring any new information, thus placing the focus on park development. The site increases in interest when more information is provided 
and historical/natural heritage associations can be made. An example of a case study of documentation level and other measures for underwater parks was compiled by Sallamaria Tikkanen of the National Board of Antiquities as follows:

Case study- The SS Mediator, Curaçao- (Nagelkerken et al. 2008)

The SS Mediator was a steel-hulled steam-powered ship, which measured almost 92 metres in length and which sank on July 5th 1884. The local newspaper, the "Curaçaosche Courant" reported eyewitness accounts of a collision between the Mediator and the German freighter Thuringa before the Mediator sank. The wreck was discovered in 1986 at a depth of 20 metres. Trained volunteers from the Maritime Archaeological and Historical Society participated in investigations between 1997 and 2003 by surveying and mapping the site.

Experts believe that the wreck has now stabilised in its submerged location, does not appear to be threatened by rapid degradation and is not an obstacle to navigation. Several reports with results of trilateration, photo documentation and sketching surveys made on the vessel. The site is adjacent to the main shipping channel for the harbour entrance and it is therefore off-limits to divers, fishermen and salvors. Access to the quay is controlled by the Curaçao Port Authority (CPA) that supervises activities in the harbour area. Exclusive permission to access the site for archaeological purposes has been granted to STIMANA (Stichting Mariene Archeologie Nederlandse Antillen) and 24-hour security is assured by the presence of a gated and guarded dockside entry, maintained by the CPA. Future plans for the wreck include:

- The submerged site, the adjacent shore and the museum will eventually become a maritime quarter.

- Historic information and case displays will be created in the Curaçao Maritime Museum.

- A facility to support diving on the underwater site will be devolped as archaeological efforts are in progress.

- Divers will be offered access to the underwater site and will be guided to and around the wreck by trained personnel.

- Submerged site maps will be added to indicate the features and to orient the divers to the parts of the ship.

- The dive facility and museum are near each other, so a tour package that transitions from orientation and education at the museum display, to outfitting, dressing and water entry, to a guided dive on the site should be easily accomplished.

- Preservation of the site will involve making videotaped views of the wreck, maps locating the site and an explanation of the archaeological efforts undertaken. 
- A limited display of artifacts found at the Mediator site has already been organized in the museum exhibition area.

- Parking and refreshments will be available in the plaza.

- There will be an archaeological conservation laboratory for public visualization of work in progress.

\section{Maintenance and usage}

A Blue park should be run by entrepreneurs or NGOs. A Blue Park shall have a marketing and development plan, which needs to be kept updated. It must be established in advance who will be responsible for both maintaining the park/trail and how it will be used after it is initially opened. Sites taken care of by the locals are better maintained when the local divers/snorkellers can check the location regularly and possible damages will be reported and fixed faster. Such local involvement also strengthens ties between locals and their own natural and cultural heritage.

\section{Special circumstances, special regulations}

Some trails and parks may require special restrictions. For example, a system of restricted access, regulating behaviour, or access for certain wrecksites which hold a particular archaeological significance. One way of dealing with this issue is to apply visitor schemes, regulating the maximum number of visitors. Another method involves the application of certification schemes, which would reward high standard operators and thus provide incentives for other operators to improve their performances also. Such a certification scheme could contain a set of continuously reviewed best practices, an application process, as well as education for applicants. Moreover, methods for monitoring and auditing the applicants would operate in conjunction with means for revoking certification and even closing operations for those not complying with the regulations and best practices. Such a scheme should include a manual for dealing with such conflicts of interest and offer a process for certification renewal.

\section{Monitoring}

The state of a Blue Park should be regularly monitored through check-ups and maintenance services. Check-ups should be undertaken on a regular basis, e.g. pre-, during and post-season. Monitoring practices should include reporting suspected infringements, incidents and pollution. Maintenance services include the restoration and updating of land-based signposts, underwater concrete signs and installations, as well as the management of buoys and jetties.

\section{Sustainability}

A Blue Park shall be sustainable and should have a scheme for waste minimisation and management. In addition, information posted within the Blue 
Park area should highlight both the environmental vulnerability and the preservation of cultural heritage.

Safety

Although it is generally understood that diving on the underwater trails takes place at the diver's own risk, unnecessary hazardous factors should me minimised or avoided as much as possible. For example, at Stora Hästö underwater nature trail, an onshore sign gives numbers to phone in case of emergency, including the coordinates of the site if a helicopter/coast guard rescue is required. Moreover, this sign acts as a disclaimer, informing visitors that in Finland, divers are expected to follow the rules of the Finnish Diving Association and that Metähallitus will not be held responsible in cases of emergency.

\section{Attitudes of the locals}

Both regional and local governments, stakeholders, focus groups and enthusiasts must be informed and involved at an early stage and thereafter kept continuously updated. Local entrepreneurs and NGO's should be encouraged to develop businesses such as dive charter companies, kayak and canoe-rentals, or even to take over management of the Blue Park. A positive attitude of the locals is also a necessary requirement for the park to function. In addition, cooperation with local entrepreneurs and clubs is essential for the success of the park/trail. For example, such activities could include organizing trips and transportation to the site, accommodation and catering services, as well as site management and monitoring.

\section{Essential services and access}

A Blue Park site should not be located on the open sea too far from the mainland and must be easy to reach by public or private transport (on land or water). Regarding infrastructure and client services, there should preferably be existing attractions and service providers, i.e. shops, restaurants, hotels and other accommodation facilities, organised tour boats and ferries, etc. Other essential servives include toilets, campfire and camping facilities. In addition, there should be sufficient car parking/coach parking/harbour facilities. Site selection will depend largely on the natural and/or cultural resource being offered to the public, as well as the strategy type when approaching the public at large. For example, if the strategy is to generate interest among the wider public, a developed infrastructure will be necessary to cope with the influx of people. By contrast, if the strategy involves enticing smaller numbers of tourists with a more targeted interest, i.e. naturalists, then the more unspoilt and undisturbed the site, the more attractive it becomes.

\section{Environmental impact}

Usage of the site should not cause environmental problems. For example, motorboats (noise, oil, waves, sewage, bilge, etc.), rubbish, diving and exca- 
vations may cause environmental problems. In addition, using the park should benefit the locals and not cause any undue conflict or inconvenience.

\section{Natura 2000 area}

If an underwater park site is set up within a Natura 2000 area, movement may be limited while special permits may be required. Moreover, if the trail/park is located in privately owned waters or the trail crosses private lands for visitors coming to the underwater trail, then the owners need to be contacted and suitable arrangements made. This may lead to problems. However, in Finland at least, in the case of underwater nature trails and where Metsähallitus-managed areas overlap with Natura areas, this was less of a problem. In Finland, if a potential trail is to be placed within a Natura 2000 area, the local environmental office needs to be contacted about the trail, with details on the location and nature of the structures being placed on the seabed. Due emphasis should be given to the fact that information plates, ropes and buoys etc., are temporary structures not fixed permanently to the seabed and which may be removed if necessary.

\section{Protected zone/Restricted zone}

An underwater archaeological site located in a protected zone should not become an underwater park. This applies specifically to areas which have either a periodic ban on visitors boating or making landfall due to important nesting/breeding times for birds or a full year-round ban on such activities in or near areas where seals are protected. By contrast, such an area may still be suitable for an underwater nature trail, particularly in an area with a relatively short tourist season, which limits the impact by visitors (See section on the Perämeri underwater nature trail). However, restricted areas used for naval and or military exercises are unsuitable for setting up any kind of Blue Park/Trail.

\section{Historical Association}

Some questions should be asked concerning potential underwater cultural trails involving shipwrecks and other underwater strucures. Has the vessel been identified? Are there historical records available? Based on the finds and records, can the route of the vessel be identified? Where was its provenance and where was it bound? Was it a merchant vessel or a warship? What was the type of the vessel and can it be dated? An interesting story behind the vessel would make such a site more exciting. For underwater nature trails we might also ask if there is there a wreck nearby which might be included as an added bonus for divers visiting the underwater nature trail or if the nearest island is historically significant or a place of historical interest? 


\section{Fragility/possible risks}

A potential underwater archaeological park site cannot be too susceptible to the possible erosion diving visitors might cause. Small changes are inevitable but unnecessary erosion and wear and tear should be avoided. A potential park/trail site should not be too sensitive to the possible harmful effects visitors might cause, with more resilient sites chosen instead. If the site/area is particularly sensitive, alternative non-impact means might be offered to visitors who wish to experience the site, i.e. ROV and drop-camera technology. A diverse flora and fauna will increase the attractiveness and complexity of the site. Various protected zones like bird-nesting or seal conservation areas may prevent setting up or limit the opening times of a park.

\section{Depth}

Overall, the underwater trail should preferably be located at a depth of less than 20 metres. Sites located deeper will reduce the numbers of divers based on their skills and diving experience, as well as reducing the time spent underwater. For nature trails, sites should preferably be located at depths of 0.5 to 10 metres. This will allow the possible inclusion of a snorkelling trail. Also, due to the relatively poor light penetration, the maximum number of species is typically found in the top 10 metres. A site where snorkelling is possible will bring underwater nature closer to the general public.

\section{Snorkelling possibility}

A site where snorkelling is possible will bring both underwater archaeology and nature closer to the general public. Snorkelling is possible if the visibility is good and the site is in shallow water. However, in shallow water, archaeological sites are often in poor condition due to wave and ice action. Similarly, underwater information plates and trail structures on a snorkelling trail may also suffer from waves and ice.

\section{Object size and trail length}

A large wreck or underwater object makes the site more visually appealing, while for underwater nature trails, the path should be of sufficient length to include as many habitats as possible. For example, the underwater nature trail at Stora Hästö measures just over 200 metres and extends across rocky macroalgal communities, blue mussel colonies, vascular plant communities and the sandy seabed.

\section{Bottom Quality}

If the bottom is easily disturbed, it can affect the visibility. The speed of sedimentation has an effect on site integrity and management. While a rock, sand or moraine bottom is best for visibility, a variable bottom type along the trail offer different habitat types and visible species of flora and fauna. 


\section{National park}

Both archaeological and natural sites could be located in a National park area. Thus, archaeology and nature could be presented together, which would increase the complexity and attractiveness of the park. In Finland, Metsähallitus is largely responsible for maintaining national parks, therefore placing a blue trail in such areas is a logical choice because of the lack of private land and/or water ownership issues. In addition, due to research carried out in the national parks, Metsähallitus often has the requisite background environmental and archaeological data for making informed choices as to the location of new trails, both terrestrial and underwater.

\section{Loose artefacts}

Loose artefacts will increase the complexity and attractiveness of the site but are also vulnerable to looting.

\section{Archaeological value}

The archaeological value of a site should be rather low but should be investigated well enough, so that additional research would not produce much new information. It could be interesting to organize an excavation on the site to coincide with a visit from recreational divers so that they could see the actual excavation process underwater.

\section{Culturo-historical value}

A site that has culturo-historical value increases its attractiveness. This value can be international, national or local. At its best a wreck can be a time capsule of conditions and people, trade routes and commercial goods or wars and weapons, state of community and seafaring of its time.

\section{Recreational value}

An underwater trail site should be properly set up, maintained and safe for divers of different skill levels. The complexity and visual appeal of the site, both above and below the waterline adds to its overall attractiveness.

\section{Weather conditions}

Strong currents and high winds will affect both access to the site and whether the diving is safe. Poor weather conditions also reduce visibility. Big waves can also remove buoys, information boards, etc. and therefore may affect the maintenance and condition of the site. If the weather is often bad, a park/trail in an exposed area will allow only limited access to visitors, making it a poor choice.

\section{Attractiveness}

Many factors affect the attractiveness of the site like the condition of the site, the story behind it, loose artefacts, ature around the site, visual appeal, uniqueness, representativeness and complexity of the site. A Blue Park should focus on 
today as well as yesterday, outlining different uses and different land- and seascapes over time (land uplift, different sea levels, etc.).

\subsubsection{WP 4: Project co-ordination and dissemination of results}

The project co-ordination includes: project management (sharing advice on project participation), being the focal point for communication between project partners (shared advice on project, chairing of meetings, creating of the project website, compiling the project's final report (based on contributions from project partners).

\subsubsection{Nordic Blue Parks Website}

While it was generally agreed that the website, as hosted by Metsähallitus, developed well with contributions made by some of the Nordic Blue Parks members, some felt that the www.metsa.fi/nordicblueparks web address was too long and not so easy to remember. Therefore, to improve our outreach potential and to gain more control over how the Blue Parks material would be presented, it was decided to create our own website for the project. Once we had established that the domain name, i.e. www.nordicblueparks.com was not in use, it was registered and the Nordic Blue Parks sites hosted on a commercial webserver.

The site presents the background information on the project, individual pages per member country detailing their activities, contact information, a links page and a photo gallery for images and videos uploaded by the Blue Park members from their various individual trails. A feedback page was also included for visitors to express their opinions about the website itself, the trails they have visited and feedback on how we might improve the trails in the future. Just before www.nordicblueparks.com came online, two similar pages called "Nordic Blue Parks-Blue Trails" and "Nordic Blue Parks" appeared on the popular internet forum Facebook. Underwater photos and videos from the Danish trail at Højklint can be viewed on the former, which is a fan page.

\subsubsection{Publicity}

Finland - The Kronprins Gustaf Adolf Blue park

- Four lectures concerning Kronprins Gustav Adolf Underwater Park and the Nordic Blue Parks Project were given at various locations between May and October 2009. These include:

- A lecture given during European Maritime Day at Helsinki City Museum (5.5. 2009).

- A lecture presented during Archaeological Sites Day at Suomenlinna Sea Fortress Auditorium, Helsinki (5.9.2009).

- A lecture given at a seminar entitled "Näkösyvyys takaisin" or ("More underwater visibility”) at Tieteiden Talo in Helsinki (16.9.2009). 
- A lecture given at the "Underwater Landscape" seminar, in which the wreck Kronprins Gustav Adolf was used as a case study. The seminar took place in Helsinki at the Kulttuuritalo (2.10.2009).

- An article concerning the Kronprins Gustav Adolf ("Kronprins Gustav Adolf - Itämeren ensimmäinen vedenalainen puisto") was published in a periodical called "Albatrossi" (Merimieseläkekassan asiakaslehti 4/2009). This article was written by Salla Pärssinen who worked for the Blue Parks Project.

Finland - Perämeri trail

- Magazine article: “Uusi luontopolku kertoo Perämerestä”. Text (in Finnish) by Essi Keskinen. Photos: Metsähallitus. Published in the Finnish dive magazine, "Sukeltaja”. Issue 4/2009, pp. 20-23. http://www.kumppania.fi/doc/Sukeltaja_4_2009_netti.pdf

- Newspaper article: "Vedenalainen luontopolku tuo uudet näkymät". Published on 2.8.2009 in the Finnish newspaper, "Kalevala”, Text (in Finnish) by Niina Rintala. Photo: Essi Keskinen/Metsähallitus.

- Newspaper article: "Vedenalainen luontopolku tuo sukeltajille uudet näkymät”. Article published on 1.8.2009 in the Finnish newspaper, "Pohjolan Sanomat". Text (in Finnish) by Niina Rintala. Photo: Essi Keskinen/Metsähallitus. http://www.pohjolansanomat.fi/cs/Satellite/ Teemat/1194623362999/artikkeli/vedenalainen+luontopolku+tuo+suk eltajille+uudet+nakymat.html

- Radio programme: Metsähallitus area biologist and Perämeri trail creator Essi Keskinen was interviewed for Radio Perämeri (YLE) ja Lapin Radio (YLE) on 29-30.7.2009.

- The Perämeri trail was featured on the snorkelling/diving forum www. snorkkeli.net (10.8.2009). Text: Essi Keskinen, Photos: Metsähallitus.

- A Blue Parks presentation was made to local stakeholders from the Archipelago Sea area at a Pan Parks meeting in Parainen, SW Finland 3.12.2009.

\section{Sweden}

- Presentation made at the Stockholm International Boat Show, Stockholm International Fairs (Stockholmsmässan) on 27.2.2009. http://www.mynewsdesk.com/se/view/pressrelease/pressinbjudanpresslunch-fredag-11-30-275076

- Presentation made at the Wilderness Fair, Stockholm International Fairs (Stockholmsmässan)on 14.3.2009.

http://www.mynewsdesk.com/se/ pressroom/stockholmsmassan/pressrelease/view/revolutionerandeuppfinning-foer-saekrare-dyk-i-diving-village-paa-vildmarksmaessanpresenteras-en-svensk-vaerldsnyhet-275377

- Presentation made at the Dalarö Tourist Office on 30.3.2009. http://www.dalaro.se/index.asp?g $=1 \& r=427$ 
- Lecture at the School of Life Sciences, Södertörn University College (Södertörns högskola) on 3.4.2009.

- Live radio interview on Radio P4 (Radio Stockholm) on 26.6.2009. http://www.sr.se/stockholm/nyheter/arkiv.asp?ProgramID=701\&Min= 2001-10-29\&PeriodStart=2009-06-25\&Period=2\&Artikel=2927954

- Live radio programme from Axmar on the radion programme Naturmorgon on 27.6.2009. http://www.sr.se/webbradio/ ?Type $=\mathrm{db} \& \mathrm{Id}=1821714$

- Live TV interview on regional television (SVT Gävle/Dala) on 24.9.2009 on 24.9.2009. http://svtplay.se/v/1703054/gavledala/ axmarsbruk_far_unik_undervattenspark?sb,k103305,115,f,-1

- Presentation at the Annual meeting for the cultural heritage sector, Swedish National Heritage Board (Riksantikvarieämbetets höstmöte) on 14.10.2009. http://www.raa.se/cms/extern/aktuellt/hostmote/ hostmote.html and http://www.raa.se/cms/showdocument/documents/ extern_webbplats/2009/hostmote/rapport_fran_hostmote_2009.pdf

- Presentation made at the Conference on Planning and Management of Sea Areas, Swedish Environmental Protection Agency (Naturvårdsverket) on 20.10.2009. http://www.naturvardsverket.se/sv/Nedre-meny/ Dokumentation-fran-kurser-och-seminarier/Dokumentationfran-konferens-om-planering-och-forvaltning-av-havsomraden/

- Presentation made at the Conference on Sustainable Tourism Development, Södertörn University College (Södertörns högskola) on 26.11.2009. http://www.tur.sh.se/conf2009/index.php?id_menu=12

- May 2010: Magazine article with colour photos highlighting Swedish wrecks and Nordic Blue Parks in the American diving magazine " $\mathrm{X}$ Ray”. Issue 36 can be viewed online at : http://www.xray-mag.com/ Subscriptions/lt.php?id=ZhlRV10BAlQDT1dRUEkFAlECXA\%3D\%3D

\section{Denmark}

- Regional TV news coverage (TV2/Fyn) of the Højklint underwater trail with footage from the actual work during installation on 7.11.2009. http://www.tv2fyn.dk/article/210056:Undervandssti- vedLangeland

- Newspaper article published in the regional paper "Fyns Amts Avis" on 5.9.2009.

- Online article published on the weblog www.sydforfyn.dk on 6.9.2009.

- Newspaper article published in the regional paper "Fyns Stiftstidende" on 3.11.2009.

- Online article published online on the weblog www.kulturplakaten.dk on 4.11.2009.

- Newspaper article published in the regional paper "Fyns Amts Avis" on 5.11.2009. 
108 Nordic Blue Parks

- Newspaper article published in the local paper "Øboen” on 10.11.2009.

- Newspaper article published in the regional paper "Fyns Amts Avis" on 15.12.2009.

- Newspaper article published in the national paper "Politiken" on 20.12.2009. 


\title{
Chapter 4. Conclusions
}

\author{
4.1 Considerations from the final group meeting \\ (December 2009)
}

The purpose of this meeting was to compile experiences (positive and negative), knowledge and opinions of the various members gained through the work packages (i.e. WP 1-3), the construction of underwater trails and the development of underwater heritage in Finland, Sweden, Norway and Denmark.

It became clear after discussing the work programmes $1-3$, that we may have some problems when we come to try to unify our approaches. For example, in WP1, suitable site analysis was discussed in terms of selection processes, as well as different approaches and goals. For the Swedes (NMM \& SWEPA), their goals are to promote awareness of the UW heritage using preconditions for establishing trails and parks and to visualise a concept for inspiring county councils to become involved in the process. They described using GIS layers for the whole coastline of Sweden including some inland lakes as possible sites.

In Finland, the cultural heritage representative described a practical approach using the combined efforts of the National Board of Antiquities and Metsähallitus and considered the level of documentation of wrecks to be an extremely important question. By comparison, the Danish Blue Park member thought that a simple regional approach in Denmark would work best employing only a few simple GIS layers. It was further considered that as per WP1, a Nordic regional map could be compiled showing a minimum of ten sites per country, while each member country could depict a more extensive spread of sites, if they chose to do so. Ideally, a nationwide spread of sites would be used in each member country but in Denmark, initially a regional spread of sites would be shown. The Danish partner said that he could at least contact other museums from the other regions in Denmark and at least get some suggestions for other sites which could be added to their national database.

Similarly, in Work Package 2 (Pressure Evaluation Matrix), it was difficult attempting to unify our approaches. For example, although the natural heritage representative from the Swedish Environmental Protection Agency suggested using an American method for ranking the pressures and threats into a ranked matrix, a further problem arose based on how to define these perceived threats and their levels. Others suggested using some sort of qualitative text based on a compilation of various approaches to use as "benchmarks". The Danish Blue Park partner commented on whether we need to compile such data at a national or regional level because of the prevailing 
situation in Denmark and suggested that the risk assessment be kept to a minimum. It was agreed that as both of the Finnish representatives for cultural and natural heritage had made a pressure/threat matrix for wrecks and UW nature, these would be sent to the rest of the group to give them a template to work from. In addition, these pressures and threats as listed in the Water Framework Directive and Hague conventions would be sent out to all the partners.

For example, the approach of the Swedish National Maritime Museums (NMM) involves a three-pronged method combining research and development, cultural historical diving and "dry" or "near-diving" experiences. In their view, the biggest challenge lies in getting the right level of "storytelling", which enriches the experience of diving, whether real or "dry". It is important to find the best means of finding the "story" to pique interest and raise awareness of the general public leading to them following up this interest by visiting a museum, website, literature etc. In their view (NMM), the main story currently concerns the development of trails and parks, while the message of UW culture is of almost secondary importance. Furthermore, political and local involvement are important prerequisites for success and involve three levels of development, i.e. general (Baltic wide), regional (Archipelago Sea, Jävle, Åland archipelago) and local (Axmar, Korppoo, Fyn).

However, other Blue Park members felt that trails/parks are just a vehicle for telling the story of UW heritage and support the more traditional media such as museums, literature and more recently, the internet. Secondly, the idea of having stakeholders, diverse administration and legislation highlighted what might be termed a "Swedish" approach and some doubt was was expressed as to whether such a model would work in Denmark or Norway. Our Blue Parks partner in Denmark stated that the active contact in the past between the diving community and museums has dropped drastically. Due to the under- or non funding of underwater heritage management, the museums cannot not do as much as they have done previously. This can be seen in the reduction of new reports of sites and a general implosion of co-operation between divers and museums. Nevertheless, some contact remains, with each regional museum having some level of amateur-related activity.

Relating to the Norwegian situation, it was stated that there has been a shift in the relationship between sports diving and cultural heritage management. It was further emphasised that in Norway, it would be necessary to gather as much information as possible to prevent from developing further a system of privatisation of archaeology combined with a tradition of secrecy. Our Norwegian partner stated that from experience, such a system just does not work and instead suggested using the information approach, viewing trails as a step in the right direction because it funnels information straight back to the people who are paying for it, i.e. the taxpayers. As a result, he considers that there has been a positive change in attitudes among divers, combined with the preservation of cultural and natural heritage, emphasising the need to focus on the positive and to crack down hard on those guilty of infractions. 


\subsection{Work packages}

\subsubsection{WP1 Suitable site analysis}

What makes a site suitable?

Shipwrecks suitable for underwater parks can be selected for a variety of reasons; either for their specific historical and natural values or simply provides an enjoyable underwater experience. One type of underwater park is that which has some kind of theme. For example, in Adelaide, southern Australia, there is an underwater heritage trail which includes four shipwrecks. Each of these vessels demonstrates the four major types of materials used in sailing vessel construction; wood, composite, iron and steel. The wrecks span the period of British shipbuilding from 1841 to 1893. Another theme park in South-Australia consists of shipwrecks which were associated with Port Victoria as an important trading port in the early 1900s.

Underwater parks can also feature other types of underwater cultural heritage than shipwrecks. For example in Ustica, Sicily, the underwater trail passes a lead-stock and a Byzantine iron anchor, while in Caeserea, Israel divers can explore structures of an ancient harbour. Underwater parks can be also parts of wider maritime heritage trails. For example in South Australia, the "River Boat Trail" on the River Murray includes - among other sites and places - over 60 shipwrecks, a lighthouse, 12 wharves, 24 jetties, a morgue and 16 surviving historical vessels.

The selected sites should be designated as an underwater park through a cooperative project between public, divers and government. The development of a new park is an excellent opportunity for a diving group to become involved in an underwater project with lasting results. By placing underwater resources in the public trust and by explaining their archaeological and historical value, the sites become important for everyone to preserve. First of all, the location has to be chosen with care. For example, the following questions should be considered:

- Has the site been researched?

- What is the scientific and recreational value of the site?

- Shall visitors experience be enjoyable?

- How suitable is it for educational use?

- What is its philosophy?

- Is it easy to access?

- How many potential users does it have?

- Will it cause navigational problems?

- What services should be provided?

- How will local people react, are they involved in planning?

Moreover, it should be realised that many sites could be chosen when compiling a "top ten" site list for a region or country. For example, in Sweden, 
apart from the Axmar and Dalarö sites, selections have been mostly made using GIS-overlays and database information. Nevertheless, to make the "perfect" choice, the planner would also need to consider a plethora of factors, including fieldwork surveys, census data, infrastructure, involved politicians, etc.

\subsubsection{WP 2- Risk matrices}

In general, underwater trails are not usually compatible with other, more traditional, industrial, maritime or military uses of coastal and maritime areas. Moreover, in existing risk matrices the effects of comparing environmental/industrial categories were found to be relatively vague.

It is important to note here that in addition to the shortcomings of the matrices listed above, the authors of the BALANCE report (www.balanceeu.org) only presented drafts of the Pressure Evaluation Cards for the Baltic Sea in the hope that these would be developed further, e.g. within HELCOM and by other Regional Seas Conventions. Moreover, the set of key information provided in these draft PEC's serve only as estimates for how far the impacts of these pressures extend from their source of origin. Indeed, the authors stressed that such impact distances are very subjective and should only be regarded as indicative since local wind/current conditions and topography/bathymetry may affect the distance of impact, citing an example where the large volume dredging of soft sediments for a gas pipe in offshore areas may have a different impact on the marine biodiversity over a larger area, than dredging of a small semi-isolated harbour. They further emphasised that the intensity by which human activities take place may vary greatly. Finally, they did not list all possible pressures in a PEC, intending it to serve mainly as a tool when compiling the PEM and EIA's (environmental impact assessments) or for the management of human activities in marine areas in general. They further stated that when discussing with stakeholders, the PEC's and PEM should illustrate clearly which human activities may cause a pressure for certain landscapes, habitats and species and it should also give an estimate of the distances at which the pressure may occur, thereby providing the information in a concise form.

In addition, it should be noted that while sometimes both nature and cultural trails may share a similar level of risk/pressure from a particular type of human activity over a similar distance, they are separate entities and may just as easily experience both environmental and anthropogenic pressures at different levels and distances. Moreover, defining these perceived threats and their levels will vary widely according to location. Therefore, the matrix table constructed for this report is at best only a simple tool for assessing and ranking pressures and threats at any one particular site, and not a universal solution. Moreover, as also suggested in the BALANCE report, the use of a qualitative text based on a compilation of various approaches to use as "benchmarks" is best applied using expert local opinion for each site. 


\subsubsection{WP3- General principles for setting up a Blue Park \& Blue Trails}

Prior to this project, no Blue Parks existed with defined and promoted natural and cultural underwater objects occurring simultaneously in a single specified area. Based on discussions at the various meetings during 2009, we found that it was difficult to define precisely what constitutes a Blue Park.

However, they may be broadly defined as areas with a set of one or more submerged natural or cultural objects/sites, and, when finalised, also have one or more underwater trails which promote these features. Further, a Blue Trail is defined as a set/planned "path" along which a diver or snorkeller travels when exploring a set of underwater ecosystems/habitats (natural object trail) or wreck and/or other cultural underwater site (culture object trail). No specific size for a Blue Park was agreed upon in the group meetings. Nevertheless, a Blue Park would ideally contain both an underwater nature and cultural trail, which would be close enough to the other to be visited on a round trip excursion in a day. However, in reality a Blue Park may only have one type of underwater trail, i.e. the nature trail in Stora Hästö or the wreck tail of the Kronprins Gustaf Adolf.

The latter may be designated a Blue Park because although the primary focus involves the wreck itself, information on the visible fauna is also included. It should also be noted that due to low light conditions and low salinity in the Baltic Sea, wrecks below 20 metres depth may not have any flora and limited fauna. In Denmark, the Højklint Trail is mainly concerned with archaeology from the Stone Age settlements, but also includes plates on the local aquatic flora and fauna. Similarly, although the Lossen trail in Norway deals primarily with the wreck and its history, information plates on aspects of the local flora and fauna will be included on the upcoming trail. Such combined approaches are ideal because they offer visitors a "two for the price of one" experience. Finally, in Finland, artificial "wrecks" have been added to both the Stora Hästö and Perämeri nature trails to make the trail more interesting and to add to the underwater experience for divers. In both cases, these "wrecks" comprise wooden and fibre-glass boats, which have been deliberately sunk and weighted with stones to keep them in place. Although artificial in nature, they have their own information plates, which serve to highlight the fate of wrecks in the Baltic Sea.

The criteria for setting up an underwater trail given here are explained in more detail in Section 3.6.3. It should be noted that these comprise a first set of basic guidelines only, not official management plans. Such detailed guidelines lie outside the scope of a project of this size. These include:

- Endurance

- Pre-survey and documentation level

- Maintenance and usage

- Special circumstances, special regulations

- Monitoring 
- Sustainability

- Safety

- Attitudes of the locals

- Essential services and access

- Environmental impact

- Natura 2000 area

- Protected zone/Restricted zone

- Historical Association

- Fragility/possible risks

- Depth

- Snorkelling possibility

- Object size and trail length

- Bottom Quality

- National park

- Loose artefacts

- Archaeological value

- Culturo-historical value

- Recreational value

- Weather conditions

- Attractiveness

\subsubsection{WP4- Outreach \& Publicity}

Since its inception, the Nordic Blue Parks project has been and continues to be well represented in the public arena through various media, including newspapers and magazines, TV and radio, public lectures, as well as its own official website. All of the work carried out so far in the member countries will be compiled in individual reports by the institutions involved, including this final report for the Nordic Council of Ministers. In addition, some of the NBP members (Swedish National Maritime Museums and Finnish National Board of Antiquities) have already begun to investigate the use of Remotely Operated Vehicles (ROVs) to create a "almost dive" experience for nondivers, thereby broadening the potential target groups which could visit underwater blue trails. Further, in Sweden and Finland, innovative and imaginative ideas are employing state-of-the-art technology to begin a pre-study to develop a virtual dive park, using digitally-enhanced film and computer graphics. Further ideas include a visualization of the landscape development over time, as well a a visit to a 17th century shipwreck in a "virtual dive".

\section{Acknowledgements}

This project has been funded by the Nordic Council of Ministers. We would like to thank the NCM representatives Gudrun Schneider (ex-NCM) and Jannica Pitkänen-Brunnsberg for all their help and assistance. 


\section{References}

Ahlström, C. "Spår av hav, yxa och penna”, Doctoral thesis.

Ahlström, C. (1981) Documentary research on the wreck at Jussarö (Annual Report of the Maritime Museum).

Ahlström, C. (1997) The Wreck at Jussarö, Finland. Looking for Leads.

Alopaeus, H. (1970) Hopeapriki eli Jussarö II (Urheilusukeltaja 10/1970).

Alopaeus, H. (1989) Esselholman laivanhylky (Urheilusukeltaja 5/1989).

Alopaeus, H. (1989) Hopeapriki (Urheilusukeltaja 3/1989).

Bonsdorff, E., Aarnio, K. \& Sandberg, E. (1991). Temporal and spatial variability of zoobenthic communities in the archipelago waters of the Nothern Baltic Sea - consequences of eutrophication? Int. Rev. Ges. Hydrobiol. 76:433-449.

Boström, C. Ecology of Seagrass Meadows in the Baltic Sea. 2001. Department of Biology and Environmental and Marine Biology, Åbo Akademi University. Academic PhD Dissertation.

Cederwall, H. \& Elmgren, R. (1980). Biomass increase of benthic macrofauna demonstrates eutrophication of the Baltic Sea. Ophelia suppl. 1:31-48.

Directive 2008/56/EC of the European Parliament and of the Council of 17 June 2008, establishing a framework for community action in the field of marine environmental policy (Marine Strategy Framework Directive) (Text with EEA relevance). 25.6.2008 Official Journal of the European Union L 164/19-40. p.22. (English).

Edgren, T. (1978) Esselholmvraket FM1978.

Edgren, T. (1978) The pottery of the Esselholm wreck (Annual report of the Maritime Museum).

Edgren, T. (1979) Mustard pots from Jussarö (Annual report of the Maritime Museum).

Ehler, Charles, and Fanny Douvere. Marine Spatial Planning: a step-by-step approach toward ecosystem-based management. Intergovernmental Oceanographic Commission and Man and the Biosphere Programme. IOC Manual and Guides No. 53, ICAM Dossier No. 6. Paris: UNESCO. 2009 (English).

Ekberg, G. et al. (2007) The maritime cultural environment around the Axmar iron works. Report 01:2007. Gävleborg Regional Museum.

Ekebom et al. 2008. Towards marine spatial planning in the Baltic Sea: BALANCE technical report 4/4. May 2008. 133 pp. www.balance-eu.org

Fast, M. \& Mertanen, T. (1996) Kuka ryösti Punapartojen hylyn? (Urheilusukeltaja 4/1996).

Flygg P., Färjare A., Fredholm M. Report: GIS-study of areas with Blue Parks potential along the Swedish coast (Preliminary title). Report in production.

Grönhagen J. \& Konttinen H. 1988: Tietoa syvyyksistä, Hylkytutkimuksen opas; Sofia Maria (Urheilusukeltaja 5/1977).

Grönhagen, J. (1980) A Wreck at Jussarö from the 18th century (Annual report of the Maritime Museum).

Grönhagen, J. (1982) Jussarön hylky 1700-luvulta (Urheilusukeltaja 1/1982).

Halme, R. (1978) Esselholmvraket. FM 1978.

Henriksson, A. (2003) Fregatti Fortunasta sukelluspuisto (Sukeltaja 5/2003).

ICOMOS (International Council for Monuments and Sites) www.international.icomos.org

ICTC (International Scientific Committee on Cultural Tourism) www.icomos.org

Ikonen, P. \& Nurmio, A. (1995) Hanko Mulan 1995. Field research report. Johnsson, R. (1988) Hiljaiset laivat sukelluksia menneisyyteen.

Kauppila, T. \& Wright, J. (1997). Ruoppausmassojen läjittämisen vikutukset vesistöön ja kalatalouteen Pohjois Airistolla. Report (in Finnish).

Kehusmaa, A. (1998) Oulun Vesimiesten ja Pohjois-Pohjanmaan museon hylkytutkimukset (Sukeltaja 4/1998).

Kinnunen, Veijo. Vrouw Maria hylyltä kesällä 2007 nostetun puunäytteen kunnon ja puun hajottajamikrobien tutkimus sekä puun alkuaineanalyysi. Pro gradu, Helsinki 2008.

Kokko, Rami. In situ -konservointi Kronprins Gustav Adolfin hylyllä 2001-2005. 2005.

Konttinen, H. (1992) Kohti syvyyksiä.

Kotilainen, Aarno.”Merenpohjan haaste kestävälle kasvulle ja hyvinvoinnille”, GeoFoorumi, Geologian Tutkimuskeskuksen Sidosryhmälehti 1/2007, 18-20. 
Kurssiraportti. Keinotekoiset riutat -hylkyjen elämää. Helsingin yliopisto 2002.

Laine, A.O., Sandler, H., Andersin, A.-B., \& Stigzelius, J. (1997). Long-term changes of macrozoobenthos in the Eastern Gotland Basin and the Gulf of Finland (Baltic Sea) in relation to the hydrographical regime. J. Sea Res. 38:135-159.

Leppäkoski, E., Helminen, H., Hänninen, J. \& Tallqvist, M. (1999). Aquatic biodiversity under anthropogenic stress: an insight from the Archipelago Sea (SW Finland). Biodiversity and Conservation 8: 55-70.

Mäki \& Sarlin (2009). "Saaristomeren kansallispuiston satamatutkimus 2008”. Metsähallitus/Forststyrelsen rapportti.

Mäki (2009). “Boaters’ movements, travel routes and the most used areas within the Archipelago National Park and its adjacent areas”. Master's thesis 85 p., 6 attachments. Department of Geography, Turku University.

Mannerkoski, P. (2007) Alfredille sukeltaminen alkaa Vänöstä (Sukeltaja 4/2007).

Marko Röhr Productions 1996:Hylyt sarja, osat 3 \& 4

MarLin: Marine and coastal activities to environmental factors matrix: http:// www.marlin.ac.uk/PDF/activities3.pdf

MarLin: The Marine Life Information Network. Marine and coastal activities to environmental factors. Webpage: http://www.marlin.ac.uk/ marinenaturaleffects.php

Memet, Jean-Bernard. "Conservation of Underwater Cultural Heritage: characteristics and new technologies”. Museum International Underwater Cultural Heritage, Unesco 240 DEC 2008.

Meriarkeologian yksikkö (2004). Kronprins Gustav Adolf -hylyn hoito ja hallinnointisuunnitelma 2004.

Metsävuori, E. (1984) Satamia joissa aallot eivät pauhaa.

Metsävuori, E. (1991) Nordstierna. Report.

Metsävuori, E. (1999) Vuosisatojen etsintä päättyi (Sukeltaja 4/1999).

Metsävuori, E. (2000) Vänön Alfred (Sukeltaja 5/2000).

Moisala, J. (1976) Alfred (Urheilusukeltaja 2/1976).

MOSS Report: Monitoring, Safeguarding and Visualizing North-European Shipwreck Sites: Common European Cultural Heritage - Challenges for Cultural
Resource Management.

http://www.nba.fi/

INTERNAT/MoSS/download/

final_report.pdf.

Museovirasto. Vrouw Maria -Selvitys tutkimuksista, tuloksista ja tulevaisuuden eri vaihtoehdoista 2007.

Nagelkerken, W., van der Giessen, T., Hayes, R. \& Knepper Dennis. (2008) "Development of Maritime Archaeological Tourism Using the Wreck of the English SS Mediator in Curaçao.” Underwater and Maritime Archaeology in Latin America and the Caribbean, eds. Margaret E. Leshikar-Denton and Pilar Luna Erreguerena, 2008.

NAR (Nederlandse Archeologische Rapporten 33), RACM Amersfoort 2006.

Naturvårdsverkets rapport nr 5566. (2007) Värdefulla kulturmiljöer under havsytan i svensk kust och skärgård. Förstudie.

Nurmio, A. (1995) Merimuseon kenttätutkimukset Hangon Mulanin hylyllä ovat päättyneet (Urheilusukeltaja 5/1995).

O’Brien, K., Hänninen, J., Kanerva, T., Metsärinne, L \& Vuorinen, I: (2003) Macrozoobenthic zonation in relation to major environmental factors across the Archipelago Sea, northern Baltic Sea. Boreal Environmental Research 8: 159-170.

Oulasvirta, P. \& Leinikki, J. (2003) Veneilyn ympäristövaikutukset luonnonsatamissa. Suomen ympäristö 605. Uudenmaan ympäristökeskus. ISBN 952-111334-0 ISBN (PDF) 952-11-1335-9. pp 91. (In Finnish and Swedish).

Rönnberg O., Lehto J., \& Haahtela, I. (1985) Changes in the occurrence of Fucus vesiculosus (L.) in the Archipelago Sea SW Finland. Ann. Bot. Fenn. 22: 231-244.

Salminen, M. Vesi vanhin voitehista Suomen vedenalaisten muinaisjäännösten hoito, kuntokartoitus- ja seurantamenetelmät osana hoitoprosessia. Pro gradu, Helsinki 2006.

Sammallahti, L. (1994) Mulanin hylyn kenttätutkimusvaihe päättymässä (Urheilusukeltaja 2/1994).

Seinä, A. \& Peltola, J. (1991). Duration of the ice seasons and statistics of fast ice thickness along the Finnish coast: 19611990. Finnish Mar. Res. 258:46.

Smit, A; van Heeringen, R.M. and Theunissen E.M. Archaeological Monitoring Standard -Guidelines for the nondestructive recording and monitoring of 
the physical quality of archaeological sites and monuments.

Sustainable Development- New Bearings for the Nordic Region. Revised edition with goals and priorities 2009-2012. ANP 2009:727 (C) Nordic Council of Ministers, Copenhagen 2009. ISBN 97892-893-1863-1, p. 40.

Sustainable Development: New Bearings for the Nordic Countries. Revised edition with goals and initiatives for 20052008. Tema Nord 2004:568 (Copenhagen: Nordic Council of Ministers, 2004), p. 127.

Swedish Environmental Protection Agency. (2007). Värdefulla kulturmiljöer under havsytan i svensk kust och skärgård. Rapport 5566: Maj 2007. Naturvårdsverket.

The Rutilus Report: Strategies for a Sustainable Development of the Underwater Cultural Heritage in the Baltic Sea Region. Swedish National Maritime Museums. Report 1267/03-51, 2006.

Tikkanen, S. (1992) Hangon Mulanin tutkimukset kesällä 1992 (Urheilusukeltaja 5/1992).
Ulfhielm B., Hansson P., Hansson J. Report: Besiktning av lokaler med natur- och kulturvärden under vattnet i Axmarreservatet. Report in production. Länsmuseet I Gävleborg/Regional Museum of Gävleborg.

UNESCO (The United Nations Educational, Scientific and Cultural Organization): www.unesco.org

Vaheri-Hyvärinen-Saari (1996) Hylkyjä Suomenlahdella ja Saaristomerellä.

Vahteri, P., Mäkinen, A., Salovius, S. \& Vuorinen, I. (2000). Are Drifting Algal Mats Conquering the Bottom of the Archipelago Sea, SW Finland? Ambio Vol. 29. No. 6.

Webpage of the Finnish Defence Forces: www.mil.fi

Wulff, F., Rahm, L. \& Rodriguez-Medina, M. (1994). Long-term and regional variations of nutrients in the Baltic Sea; 1972 1991. Finnish Mar. Res. 262:35-50. 



\section{Appendix 1}

\begin{tabular}{|c|c|c|}
\hline Country & Natural heritage & Cultural heritage \\
\hline Finland & $\begin{array}{l}\text { Metsähallitus/Forststyrelsen } \\
\text { Kevin O'Brien, Marine biologist, } \\
\text { Metsähallitus/ Natural Heritage Services, } \\
\text { Kärsämäentie 8, } \\
20300 \text { Turku, Finland. } \\
\text { Tel:+358 } 407327672 \\
\text { E-mail: kevin.obrien(at)metsa.fi } \\
\text { Website: www.metsa.fi } \\
\text { Jan Ekebom, Senior Advisor, } \\
\text { Marine and Freshwater Biology, } \\
\text { Metsähallitus/Natural Heritage Services }\end{array}$ & $\begin{array}{l}\text { National Board of Antiquities } \\
\text { Sallamaria Tikkanen, Researcher, } \\
\text { The National Board of Antiquities, } \\
\text { Maritime Archaeology Unit, } \\
\text { Hylkysaari, Fl-00570 Helsinki, Finland. } \\
\text { Telephone:+358 } 940509057 \\
\text { Fax: + } 358940509060 \\
\text { E-mail: sallamaria.tikkanen(at)nba.f } \\
\text { Website: http://www.nba.fi }\end{array}$ \\
\hline Sweden & $\begin{array}{l}\text { Naturvårdsverket } \\
\text { Cecilia Lindblad, Senior Advisor, } \\
\text { The Swedish Environmental Protection } \\
\text { Agency (SEPA), } \\
\text { Valhallavägen 195, } \\
10648 \text { Stockholm, Sweden } \\
\text { Telephone: +46 } 86981295 \\
\text { E-mail: ceci- } \\
\text { lia.lindblad(at)naturvardsverket.se } \\
\text { Website: www.naturvardsverket.se }\end{array}$ & $\begin{array}{l}\text { National Maritime Museums } \\
\text { Pernilla Flygg, Curator, Unit of Archaeology, } \\
\text { The Swedish National Maritime Museums, } \\
\text { P.O. Box 27131, } \\
\text { SE-102 52, Stockholm. } \\
\text { Telephone: +46 (0)8 } 51955830 \\
\text { Fax: +46 (0)8 } 51954959 \\
\text { E-mail: pernilla.flyg(at)maritima.se } \\
\text { Website: www.maritima.se } \\
\text { Andreas Olsson, Archaeology Unit Manager } \\
\text { The Swedish National Maritime Museums } \\
\text { P.O. Box } 27131 \text {, } \\
\text { SE-102 52, Stockholm } \\
\text { Telephone: +46 (0)8 } 51954956 \\
\text { Mobile: +46 (0)70 } 5195120 \\
\text { E-mail: andreas.olsson(at)maritima.se }\end{array}$ \\
\hline Norway & $\begin{array}{l}\text { County Governor of } \varnothing \text { stfold (withdrew } \\
\text { from project) }\end{array}$ & $\begin{array}{l}\text { Directorate for Cultural Heritage } \\
\text { Ivar Aarestad, Riksantikvaren } \\
\text { Dronningsgate } 13 \\
\text { P.O. Box } 8196 \text { Dep } \\
\text { N-0034 Oslo } \\
\text { Telephone: +47-98 } 202849 \\
\text { E-mail: iaa(at)ra.no } \\
\text { Website: http://www.ra.no } \\
\text { Desiree Nævdal, Saksbehandler/arkeolog } \\
\text { Telephone: +47 } 48882948 \\
\text { Norsk Maritimt Museum/ Maritime Museum of } \\
\text { Norway } \\
\text { Bygdøynesveien } 37 \\
\text { NO-0286 OSLO } \\
\text { E-mail: desiree.nevdal(at)marmuseum.no }\end{array}$ \\
\hline Denmark & No partner & $\begin{array}{l}\text { Langelands Museum } \\
\text { Otto Uldum, Museum inspector } \\
\text { Jens Winthersvej 12, } \\
5900 \text { Rudkøbing, Denmark. } \\
\text { Telephone:+45 } 63516300,+4563516306 \\
\text { E-mail: ou(at)langelandkommune.dk } \\
\text { Website: www.langelandsmuseum.dk }\end{array}$ \\
\hline
\end{tabular}




\section{Definitions}

\section{Blue Park}

These are defined as areas with a set of one or more submerged natural or cultural objects/sites, and, when finalised, also has one or several underwater trails, which promote the features therein. Although a specific size for a Blue Park has not been set, it would ideally contain both an underwater nature and cultural trail, which would be close enough to be visited on a round trip excursion in a day. However, in reality a Blue Park may only have one type of underwater trail, i.e. the nature trail in Stora Hästö or the wreck tail of the Kronprins Gustaf Adolf.

\section{Blue Trail}

We define a Blue Trail as a set/planned "path" along which a diver or snorkeller travels when exploring a set of underwater ecosystems/habitats (natural object trail), wreck and/or other cultural underwater site (culture object trail). This path may use guide ropes and buoys to direct the visitor and information plates about the site being visited are placed strategically along the route.

\section{Culture}

Culture can be defined as the whole complex of distinctive spiritual, material, intellectual and emotional features that characterise a community, society or social group. It includes not only arts and literature, but also modes of life, the fundamental rights of the human being, value systems, traditions and beliefs. Culture encompasses the living or contemporary characteristics and values of a community as well as those that have survived from the past. (ICOMOS, ICTC, 2002)

\section{Cultural Heritage}

This is an expression of the ways of living developed by a community and passed on from generation to generation, including customs, practices, places, objects, artistic expressions and values. Cultural Heritage is often expressed as either Intangible or Tangible Cultural Heritage. (ICOMOS, ICTC, 2002)

\section{Cultural Landscapes}

These are landscapes that describe those places and landscapes that have been shaped or influenced by human occupation. They include agricultural systems, modified landscapes, patterns of settlement and human activity, and the infrastructure of production, transportation and communication. The concepts of cultural landscapes can be useful in understanding the patterns of activity as diverse as industrial systems, defensive sites and the nature of towns or villages. (ICOMOS, ICTC, 2002; http://www.international.icomos.org) 


\section{Cultural Resources}

Cultural resources encompass all of the Tangible and Intangible Heritage and living Cultural elements of a community. (ICOMOS, ICTC, 2002)

\section{Cultural Tourism}

This is essentially that form of tourism that focuses on the culture, and cultural environments including landscapes of the destination, the values and lifestyles, heritage, visual and performing arts, industries, traditions and leisure pursuits of the local population and host community. It can include attendance at cultural events, visits to museums and heritage places and mixing with local people. It should not be regarded as a definable niche within the broad range of tourism activities, but encompasses all experiences absorbed by the visitor to a place that is beyond their own living environment. (ICOMOS, ICTC, 2002)

\section{Ecotourism}

The International Ecotourism Society (TIES) give the following definition which has been widely accepted:

"responsible travel to natural areas that conserves the environment and improves the well-being of local people.” This means that travellers must think and act responsibly in all aspects of their holiday experience in order to minimise their impacts on the environment and local community. In addition, ecotour companies must hold principles and practices that seek to either preserve/ conserve the environment and wildlife whilst protecting and empowering the local people. (www.ecotourism.org)

\section{Natural Heritage}

Natural heritage designates outstanding physical, biological and geological features; habitats of threatened plants or animal species and areas of value on scientific or aesthetic grounds or from a conservation perspective. (UNESCO definition; www.unesco.org) 